US Army Corps of Engineers $S_{\circledast}$

Engineer Research and

Development Center

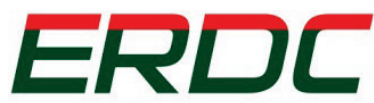

INNOVATIVE SOLUTIONS for a safer, better world

\title{
Performance of HESCO Bastion Units Under Combined Normal and Cyclic Lateral Loading
}

Ghassan K. Al-Chaar, Marion L. Banko, Brian Eick, and

February 2017

Thomas A. Carlson

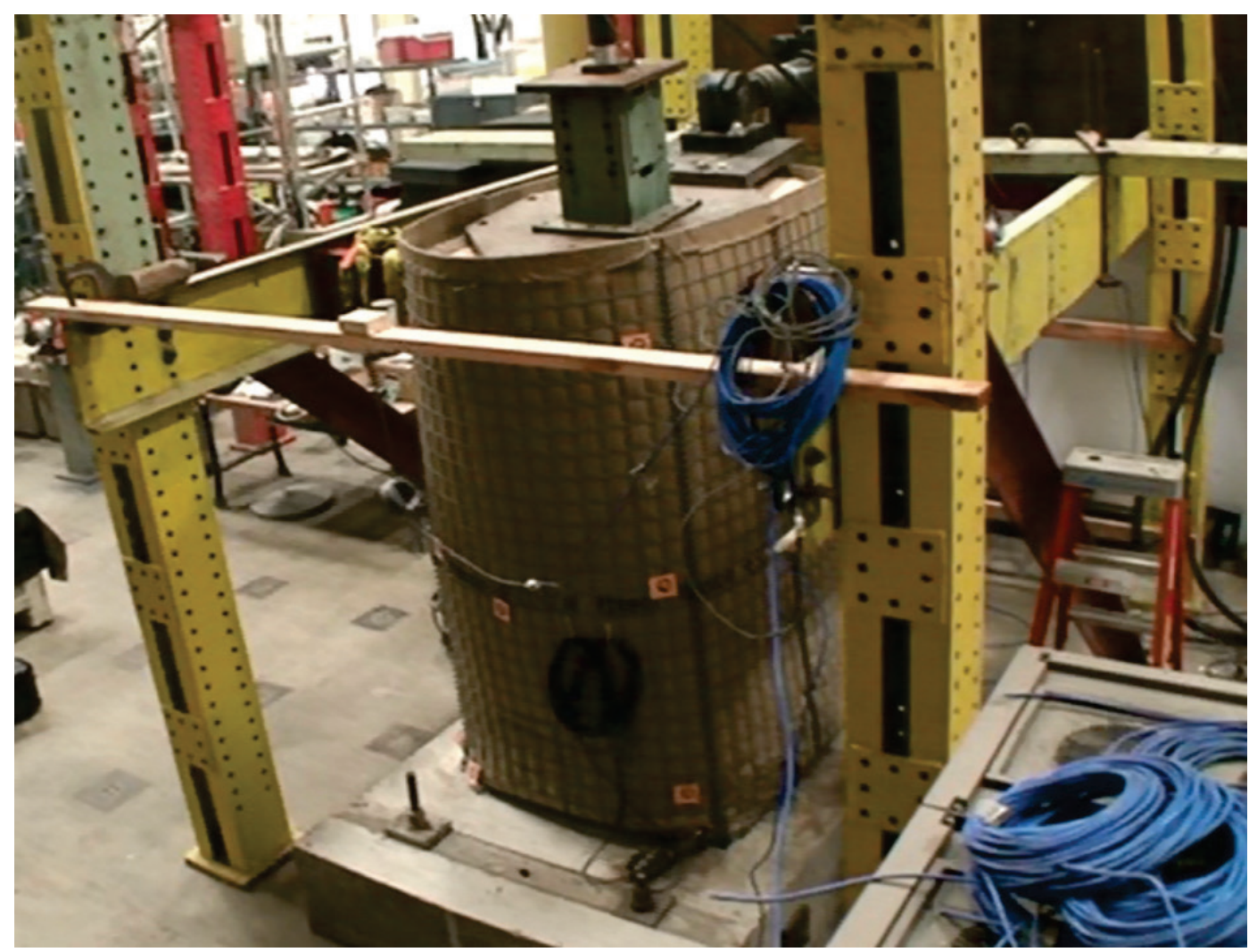


The U.S. Army Engineer Research and Development Center (ERDC) solves the nation's toughest engineering and environmental challenges. ERDC develops innovative solutions in civil and military engineering, geospatial sciences, water resources, and environmental sciences for the Army, the Department of Defense, civilian agencies, and our nation's public good. Find out more at www.erdc.usace.army.mil.

To search for other technical reports published by ERDC, visit the ERDC online library at http://acwc.sdp.sirsi.net/client/default. 


\section{Performance of HESCO Bastion Units Under Combined Normal and Cyclic Lateral Loading}

Ghassan K. Al-Chaar, Marion L. Banko, Brian Eick, and Thomas A Carlson, Construction Engineering Research Laboratory

U.S. Army Engineer Research and Development Center

2902 Newmark Drive

Champaign, IL 61822

Final report

Approved for public release; distribution is unlimited.

Prepared for U.S. Army Engineer District-Kansas City

601 E. 12th Street

Kansas City, MO 64106

Under Project P2 445442, “Laboratory Tests of HESCO Bastion Units for Design Minimum Military Requirements" 


\section{Abstract}

To help reduce the costs and logistical requirements for establishing forward operating bases (FOBs), the U.S. Army investigates construction methods that use indigenous materials in place of commercial materials manufactured far away. An established construction system called the HESCO bastion, currently used in theater for force protection, derives its mass and load resistance from indigenous soils placed in manufactured steel and geotextile containment modules. Using this system for other FOB structures, such as soldier housing, could greatly reduce costs and logistical burdens for Class 4 construction materials. Before developing such applications, however, the load-resisting characteristics of HESCO units must be tested for incorporation into new engineering guidance.

In this study a HESCO unit was filled with dry, coarse sand and subjected to combination of normal and lateral loads at four separate intensities. The interaction of normal and lateral loads was investigated, as well as the cyclic loading hysteresis. A lateral load capacity for HESCO bastions was determined based on the applied normal load. The results validated the suitability of HESCO units as load-bearing structural members for temporary soldier housing in FOBs located in remote areas of operation.

DISCLAIMER: The contents of this report are not to be used for advertising, publication, or promotional purposes. Citation of trade names does not constitute an official endorsement or approval of the use of such commercial products. All product names and trademarks cited are the property of their respective owners. The findings of this report are not to be construed as an official Department of the Army position unless so designated by other authorized documents. 


\section{Contents}

Abstract............................................................................................................

Figures and Tables............................................................................................................vii

Preface ............................................................................................................... ix

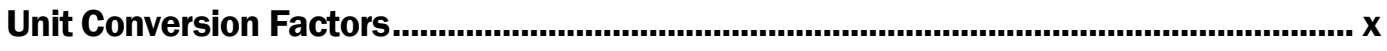

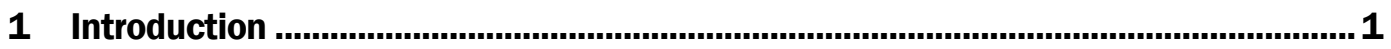

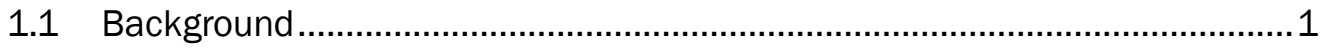

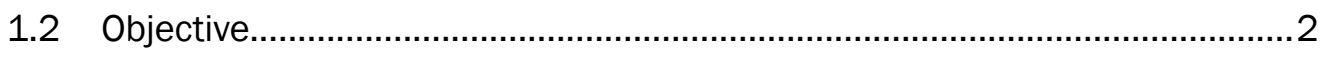

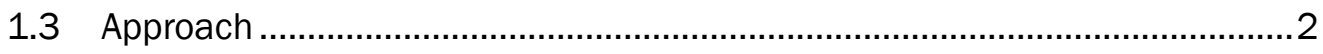

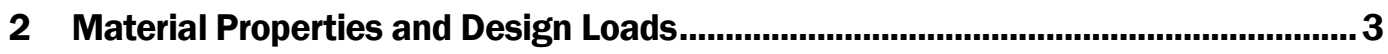

2.1 HESCO steel mesh and fabric ................................................................. 4

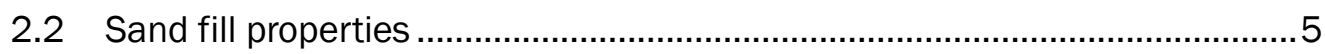

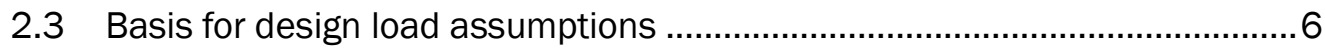

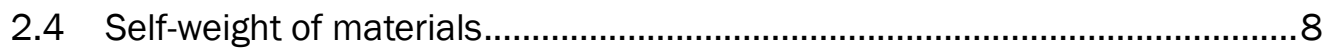

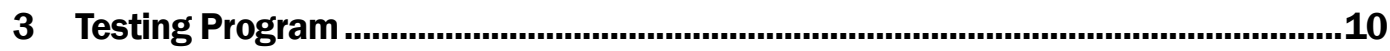

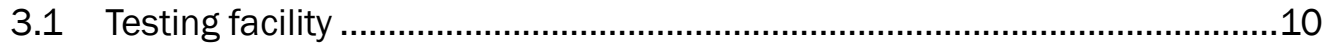

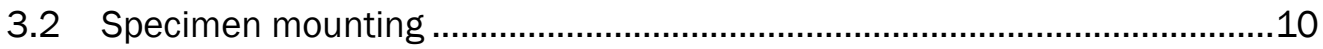

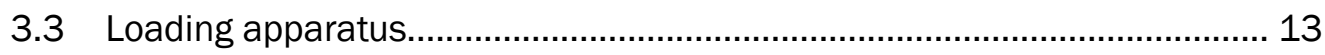

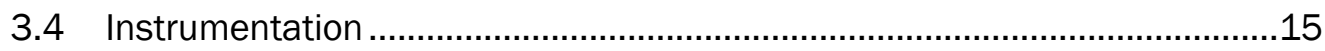

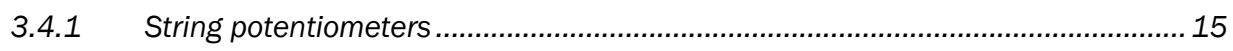

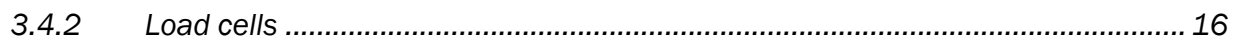

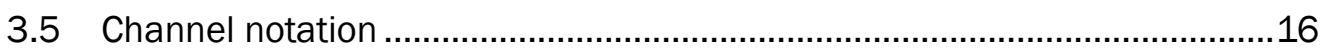

3.6 Selection of cyclic loading protocol .........................................................17

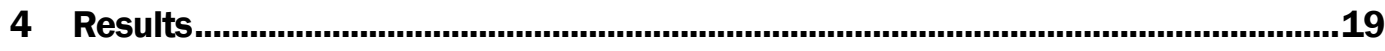

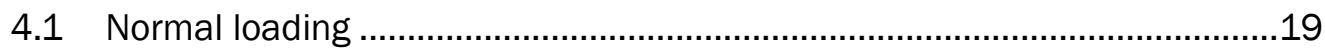

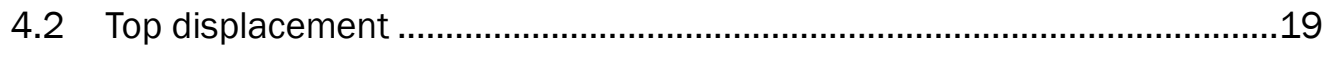

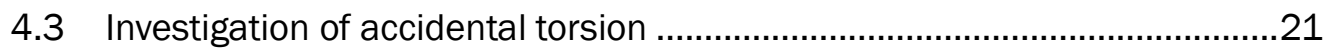

4.4 Measured load versus time ...................................................................24

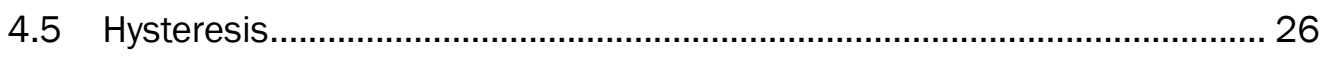

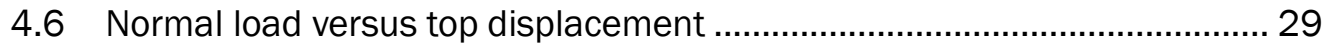

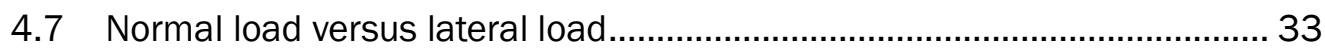

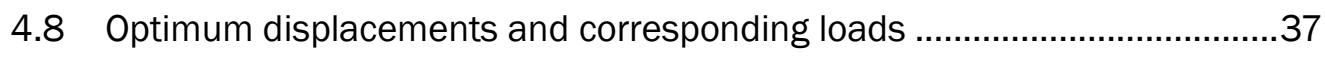

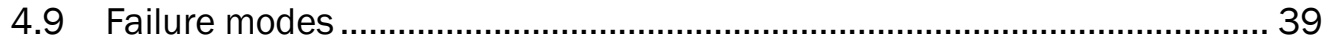

4.10 Summary of results .......................................................................4

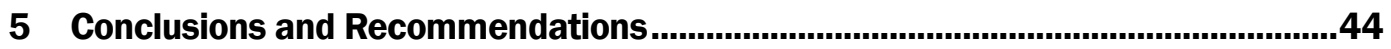

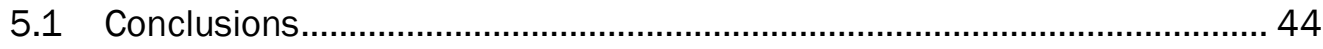

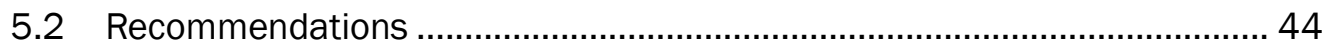




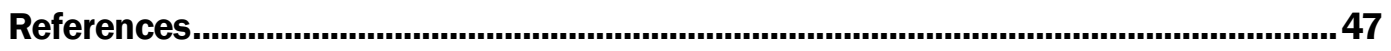

Appendix A: HESCO Building Design ........................................................................48

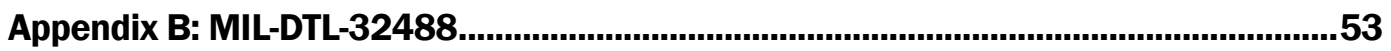

Report Documentation Page 


\section{Figures and Tables}

\section{Figures}

Figure 1. HESCO bastion welded wire mesh (WWM) panels. ..............................................

Figure 2. Lined HESCO units interconnected to form a barrier. ........................................... 4

Figure 3. Typical HESCO bastion housing floor plan. ......................................................... 6

Figure 4. HESCO company's housing structure using HESCO bastion walls and wooden roof trusses [4].

Figure 5. HESCO unit plan view showing three boundary conditions: (a) one adjacent unit, (b) two adjacent units at corner, and (c) two adjacent units at middle of wall.

Figure 6. HESCO bastion bowing: (a) corner cell bows in two directions, (b) edge cell bows in three directions, and (c) intermediate cell bows in two directions...

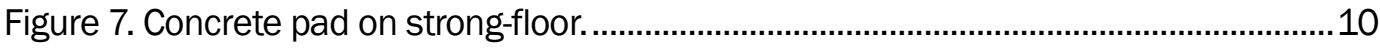

Figure 8. Exterior of unfilled HESCO bastion......................................................................11

Figure 9. Interior of unfilled HESCO bastion showing threaded rod vertically penetrating the concrete pad.

Figure 10. Photograph of special load-transfer assembly used in testing program...........12

Figure 11. Detail showing threaded rod connection with hemispherical bushing to allow rotation of the threaded rod.

Figure 12. Isometric drawing of test setup (NW view).

Figure 13. Drawing of steel plate for applying normal loading to top of test specimen, showing attachment point for horizontal actuator and center slot for threaded rod.

Figure 14. Dimensioned drawing of test setup (north elevation view).

Figure 15. Laboratory photograph showing the connection between the reaction wall and the steel plate atop the HESCO bastion.

Figure 16. Instrumentation layout and channel notation.................................................... 17

Figure 17. HESCO bastion lateral displacement cycle...................................................18

Figure 18. Run 1 measured top displacement (2 in. targeted).............................................19

Figure 19. Run 2 measured top displacement (4 in. targeted).........................................20

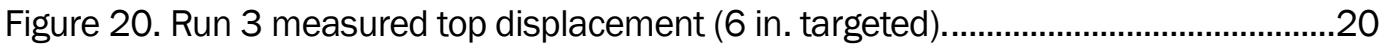

Figure 21. Run 4 measured top displacement (6 in. targeted)..........................................21

Figure 22. Run 1 measured displacement at mid-height..................................................22

Figure 23. Run 2 measured displacement at mid-height..................................................22

Figure 24. Run 3 measured displacement at mid-height. ................................................23

Figure 25. Run 4 measured displacement at mid-height. ...................................................23

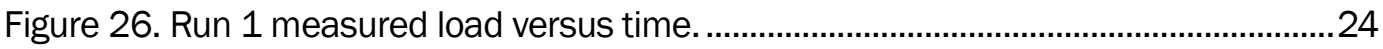

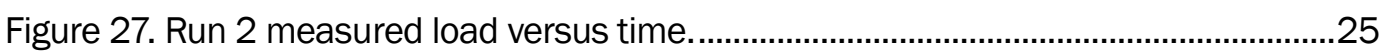

Figure 28. Run 3 measured load versus time. ...............................................................25 


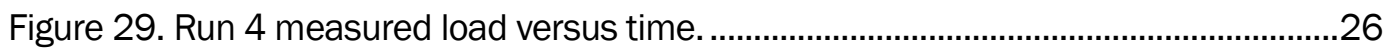

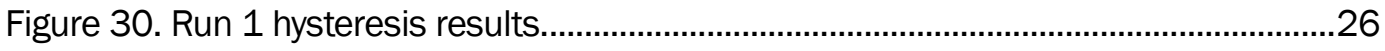

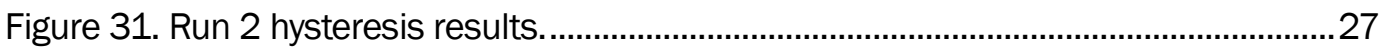

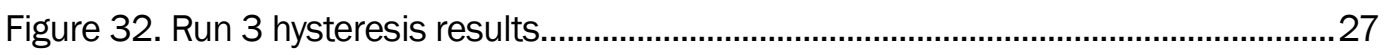

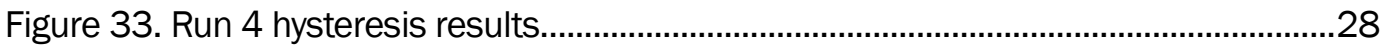

Figure 34. Run 1 measured normal load versus top displacement raw data (a)

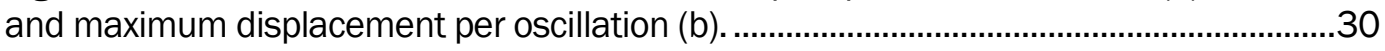

Figure 35. Run 2 measured normal load versus top displacement raw data (a)

and maximum displacement per oscillation (b).

Figure 36. Run 3 measured normal load versus top displacement raw data (a)

and maximum displacement per oscillation (b).

Figure 37. Run 4 measured normal load versus top displacement raw data (a) and maximum displacement per oscillation (b).

Figure 38. Run 1 normal load versus lateral load raw data (a) and maximum lateral load per oscillation (b).

Figure 39. Run 2 normal load versus lateral load raw data (a) and maximum

lateral load per oscillation (b)

Figure 40. Run 3 normal load versus lateral load raw data (a) and maximum lateral load per oscillation (b)

Figure 41. Run 4 normal load versus lateral load raw data (a) and maximum lateral load per oscillation (b) 37

Figure 42. Photographs of failure modes seen in HESCO unit..........................................40

Figure 43. Comparison of load shedding curves for each run $(a-c)$...

\section{Tables}

Table 1. Typical shear strength values of different soil types. ............................................... 5

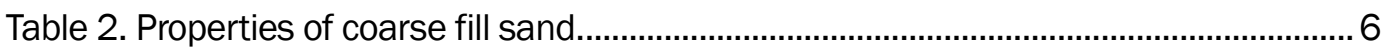

Table 3. Total roof load for HESCO building design. ........................................................... 6

Table 4. Self-weight of HESCO materials. ........................................................................... 8

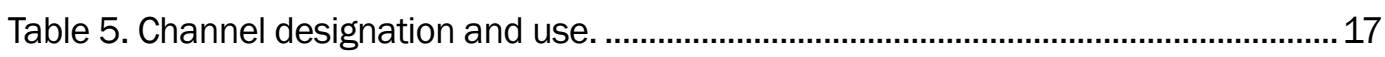

Table 6. Applied normal load for each test run................................................................19

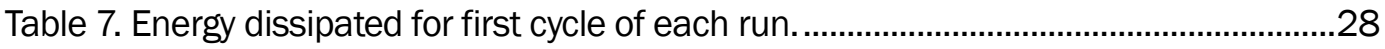

Table 8. Run 1 optimum displacements and corresponding loads....................................38

Table 9. Run 2 optimum displacements and corresponding loads....................................38

Table 10. Run 3 optimum displacements and corresponding loads. .................................39

Table 11. Run 4 optimum displacements and corresponding loads. ................................39 


\section{Preface}

This study was conducted for U.S. Army Engineer District-Kansas City, U.S. Army Corps of Engineers, under Project P2 445442, "Laboratory Tests of HESCO Bastion Units for Design Minimum Military Requirements"; Military Interdepartmental Purchase Request MIPRW58XUW41133620, dated 9 May 2014. Funding was provided through the Virtual Forward Operating Base (VFOB) - Contingency Basing Integration Technology Evaluation Center (CBITEC). The technical monitor was Kelly Miller, Chief, Military Construction Section Plans, Programs \& Project Management, Kansas City District (CENWK-PM-MM).

The work was performed by the Materials and Structure Branch of the Facilities Division (CEERD-CFM), U.S. Army Engineer Research and Development Center - Construction Engineering Research Laboratory (ERDCCERL). At the time of publication, Vicki L. Van Blaricum was Chief, CEERD-CFM; Donald K. Hicks was Chief, CEERD-CF; and Kurt Kinnevan (CEERD-CZT) was the Technical Director for Adaptive and Resilient Installations. The Deputy Director of ERDC-CERL was Dr. Kirankumar Topudurti and the Director was Dr. Ilker Adiguzel.

The managers of ERDC-CERL CBITEC investigations were H. Garth Anderson and Tom Decker, CEERD-CNE. The authors thank them for their recommendations about system applicability to the CBITEC program. The authors are also grateful for the contributions by laboratory research assistants Tanner Wood, Andrew Weiss, and Sarah A. Aboul-Hosn, who assisted in the test setup. We thank Jonathan Trovillion for technical support, and also Keith Anderson and Mike Pickup of HESCO Bastion Ltd. (Leeds, UK) for contributing the bastion units used in the testing program.

The Commander of ERDC was COL Bryan S. Green and the Director was Dr. Jeffery P. Holland. 


\section{Unit Conversion Factors}

\begin{tabular}{|l|l|l|}
\hline Multiply & By & To Obtain \\
\hline cubic feet & 0.02831685 & cubic meters \\
\hline feet & 0.3048 & meters \\
\hline inches & 0.0254 & meters \\
\hline kilopounds (force) & 4.4482216 & kilonewtons \\
\hline pounds (mass) & 0.45359237 & kilograms \\
\hline pounds (mass) per square foot & 4.882428 & kilograms per square meter \\
\hline square feet & 0.09290304 & square meters \\
\hline square inches & $6.4516 \mathrm{E}-04$ & square meters \\
\hline
\end{tabular}




\section{Introduction}

\subsection{Background}

The U.S. Army has a continuing interest in reducing the logistical requirements and costs for establishing forward operating bases (FOBs). Construction methods that incorporate indigenous materials readily available in the mission's operating area can significantly reduce the need to transport expensive bulk construction materials over long distances by transport aircraft or motor convoys. Specific desirable features for alternate construction systems are improved force protection and reduced transportation and logistics burdens related to Class 4 construction materials.

A product called the HESCO Bastion* has long been used in Army areas of operation to assemble semipermanent protective barriers. It is produced in various sizes as a modular unit that can be joined in configurations suitable for force protection as well as flood-control barriers and other applications. Each HESCO unit consists of a cage-like, collapsible welded wire mesh that is used with a geotextile liner. HESCO units are set up onsite and filled with soil or sand, as available at the construction site, to provide load resistance. The practical advantages of this product for military users are shipping compactness and ease of setup. An additional potential advantage for Army managers and planners is that the technology is considerably more affordable than construction materials and systems designed for civilian and consumer applications, particularly when including the costs of global logistics and security issues related to protecting convoys.

The availability of HESCO units at FOBS has spurred interest in investigating their use as load bearing members for in-theater soldier housing, which could offer the same relative affordability and ease of construction realized in its conventional uses. However, because this technology was not designed for residential applications, engineering standards would be needed to guide the designers of soldier contingency housing. In order for engineers to qualify a structural component, they must calculate component capacities to ensure that the values exceed the predicted demands.

\footnotetext{
* Manufactured by HESCO Bastion Ltd. (Leeds, UK).
} 
While component demands are based on expected member loads, capacities depend mainly on material properties and the behavior of the component under loading.

In order to support the Army's interest in using indigenous construction materials to reduce the logistics burden for housing soldiers in areas of operation, the Engineer Research and Development Center, Construction Engineering Research Laboratory (ERDC-CERL) designed and executed a testing program to help qualify HESCO units for use in contingency housing structures.

\subsection{Objective}

The objective of this study was to determine the load capacity of a selected HESCO bastion unit to qualify them as bearing members that can safely be used to construct FOB soldier housing.

\subsection{Approach}

ERDC-CERL performed a series of four pseudodynamic laboratory tests on an individual HESCO unit filled with sand and subjected to a combination of normal and lateral loads. The test specimen was subjected to combined shear and compressive loading in order to determine the corresponding ultimate strengths. The properties of the prefabricated HESCO bastion materials (i.e., wire mesh and geotextile liner) were held constant for all tests. HESCO unit dimensions and material properties are specified in Chapter 2. 


\section{Material Properties and Design Loads}

The HESCO bastion is a three-dimensional rectangular unit consisting of four welded zinc-aluminum-coated steel wire panels joined at their edges by means of vertical helical-coil joints. Each unit is shipped and stored in a flat (collapsed) state. It sets up into a cage-like configuration that is designed to receive a heavy-duty, nonwoven polypropylene geotextile liner to form a container that can be filled with granular indigenous materials such as soil or sand. The units are manufactured in a variety of shapes and sizes, such as a single basket (see Figure 1) or a row of interconnected units (Figure 2).

Figure 1. HESCO bastion welded wire mesh (WWM) panels.

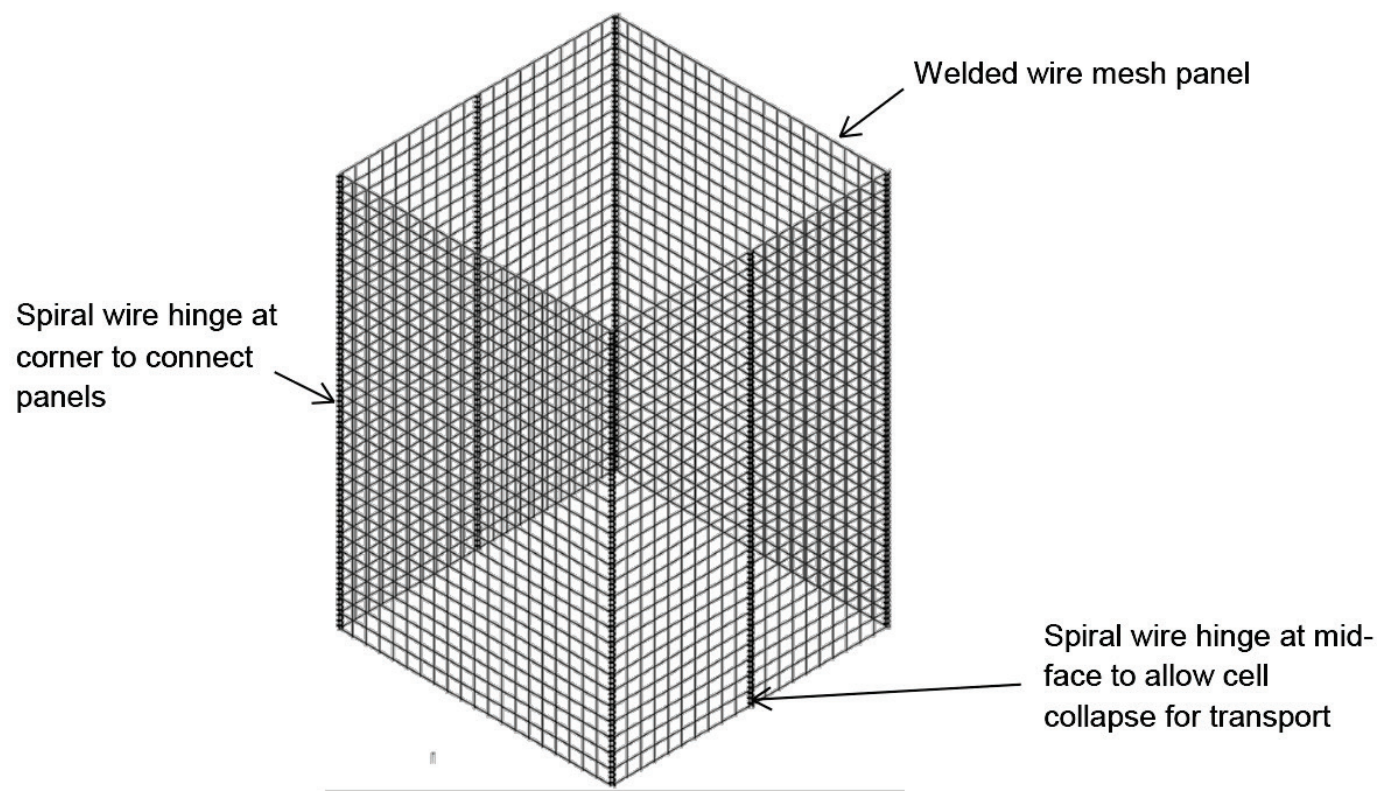


Figure 2. Lined HESCO units interconnected to form a barrier.

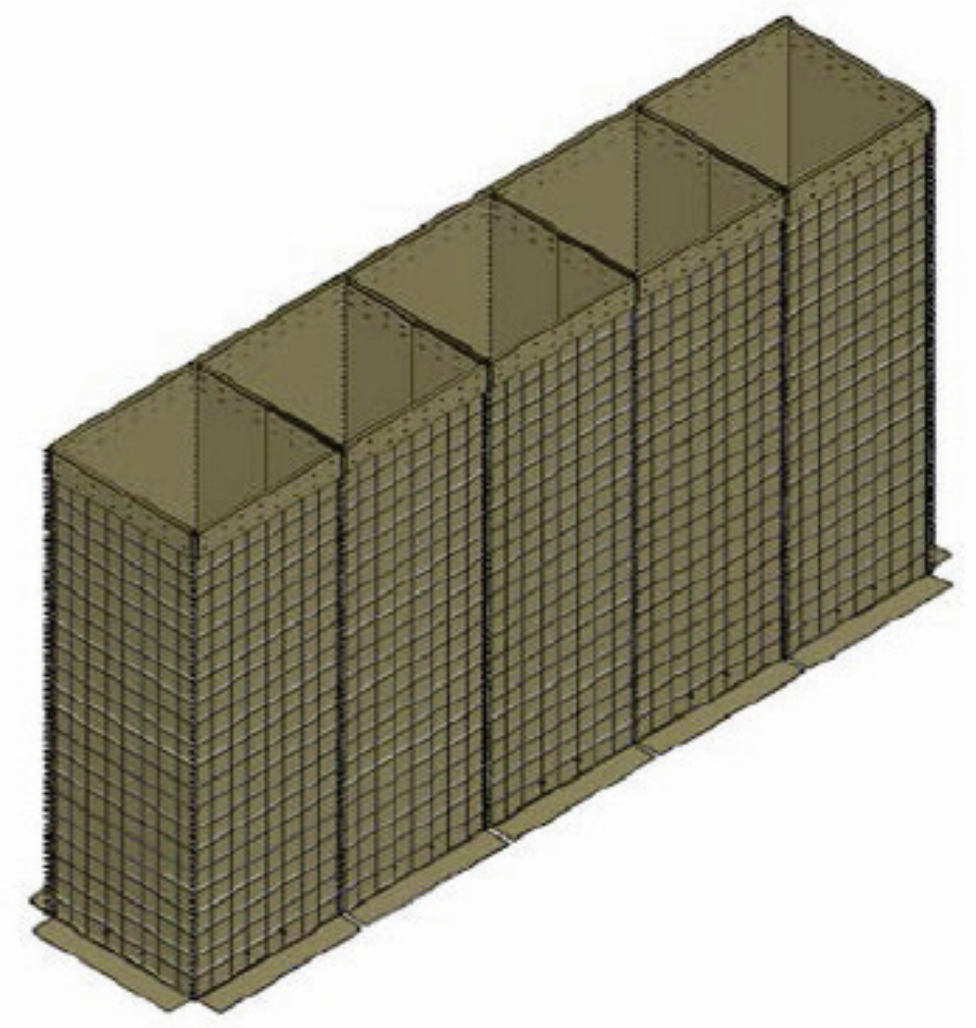

The HESCO unit used in these tests had a square cross-section measuring $3.5 \times 3.5 \mathrm{ft}$ and height of $7 \mathrm{ft}$. The design of the testing apparatus required that the HESCO unit not be filled completely, so the tested unit had a nominal height of $6 \mathrm{ft}-6$ in. The wire mesh will have a gage of 12 American SWG with 3 in. $x 3$ in. spacing and a tensile strength between 80 and 110 ksi. The geotextile is a heavy-duty, nonwoven, permeable, polypropylene fabric.

The design of the testing apparatus required that a few in. of height not be filled with sand; therefore a nominal height of the tested unit was $6.5 \mathrm{ft}$. The test specimen was fabricated per MIL-DTL-32488, Detail Specification: Expeditionary Barrier System (EBS) [1] (see Appendix B).

\subsection{HESCO steel mesh and fabric}

The HESCO panels are fabricated from AISI* 1010 carbon steel, with a wire diameter of $4 \mathrm{~mm}$ and mesh spacing of 3 in. in both directions. The spiral wire hinges that connect individual panels are made of the same

\footnotetext{
* American Iron and Steel Institute, Washington, DC.
} 
AISI 1010 steel. The spirals have an inside diameter of 0.857 in. and a pitch of 1 inch. Wires are fabricated to have a minimum yield strength of 92,800 psi and an ultimate strength of 99,350 psi. All steel components are coated with a zinc- $5 \%$ aluminum-mischmetal coating per ASTM Standard Specification B750 [2] requirements, and deposition requirements of ASTM A856 [3]. (See Table 1 in MIL-DTL-32488 [1].)

The nonwoven polypropylene geotextile fabric used for the liner is 54 mils $(1.37 \mathrm{~mm}$ ) thick, and the wide-width tensile strength is $85 \mathrm{lb} / \mathrm{in}$. (See Table 2 in MIL-DTL-32488[1], Appendix B, for more information.)

\subsection{Sand fill properties}

The most common types of fill used in HESCO bastions are granular soils, typically gravel and sand, which are highly desirable due to high permeability (to allow quick drainage) and high shear strength. Fine soils such as clay and silt also can be used, but they are less desirable due to their low permeability. These soils may be used individually or in combination with one another to achieve a required design shear strength.

The type of fill used is selected to provide the properties the bastion must have for the specific application. For structural applications, the soil must have relatively high shear strength so the structure does not fail due to high soil shearing. This means that the soil must be dry, because moisture expands dry soil and reduces friction between the particles, which greatly reduces its overall shear strength and load-bearing capacity. Table 1 provides typical shear strength values for general soil types under dry conditions. As shown in the table, the granular soils have much greater shear resistance than fine-grained clay.

Table 1. Typical shear strength values of different soil types.

\begin{tabular}{|l|l|}
\hline Fill & Shear Resistance, $\mathbf{T}(\mathbf{p s i})$ \\
\hline Coarse Sand & 6373 \\
\hline Fine Sand & 5271 \\
\hline Gravel & 6853 \\
\hline Clay & 3727 \\
\hline
\end{tabular}

For this study, only dry, coarse sand was used as to fill the test specimen. Table 2, summarizes the properties of the test sand. 
Table 2. Properties of coarse fill sand.

\begin{tabular}{|l|l|}
\hline Property & Value \\
\hline Density of Dry Sand & $1.38 \mathrm{gm} / \mathrm{cm} 3$ \\
\hline Moisture Content of Sand & $2.69 \%$ \\
\hline
\end{tabular}

\subsection{Basis for design load assumptions}

One possible floor plan for a HESCO-based housing system is shown in Figure 3 below. A full set of engineering drawings for such a structure is provided in Appendix A. Based on this design, the total roof load for HESCO bastion walls to support is shown in Table 3.

Figure 3. Typical HESCO bastion housing floor plan.

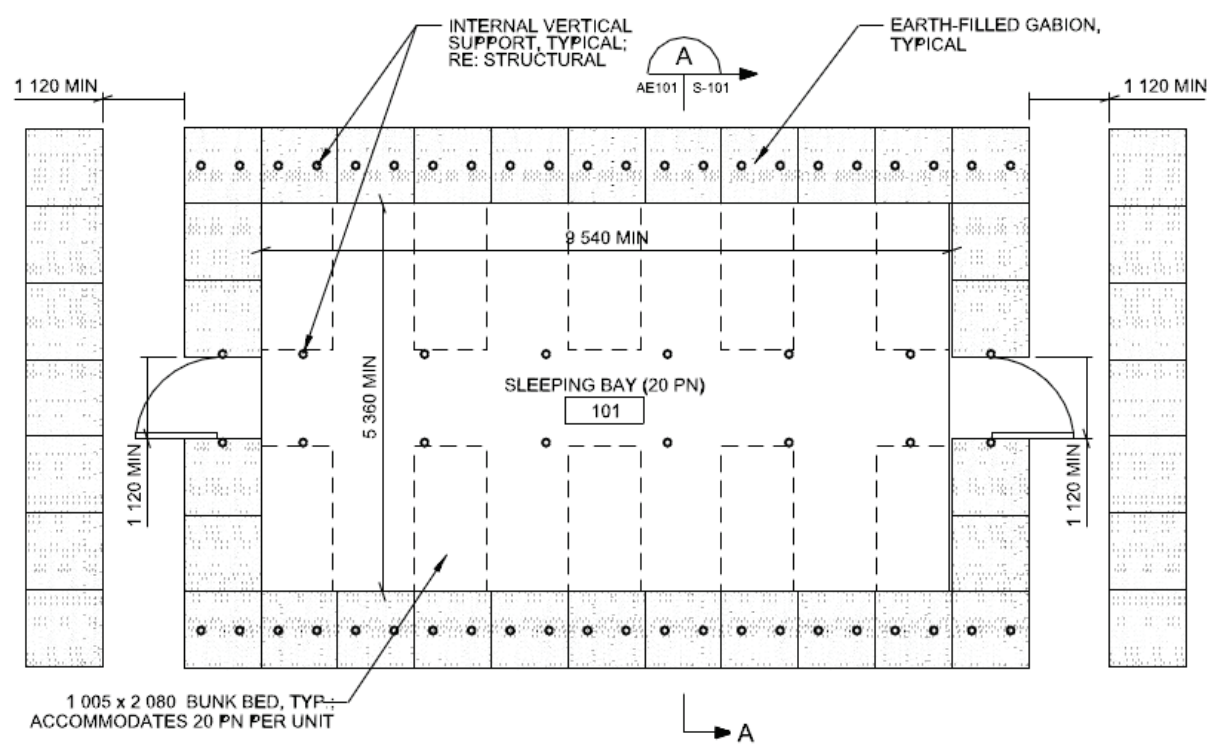

Table 3. Total roof load for HESCO building design.

\begin{tabular}{|l|c|}
\hline \multicolumn{1}{|c|}{ Description } & Load (psf) \\
\hline Live Load & 20 \\
\hline I-Joists & 8 \\
\hline Plywood & 2 \\
\hline Sandbags & 176 \\
\hline Total Roof Load & 206 \\
\hline
\end{tabular}


The roof described in Appendix A has a volume of 784 cubic feet, so the total roof weight is $161,504 \mathrm{lb}$. The roof is supported by 18 HESCO units, so the load on each HESCO unit is 8,772 lb.

There are several roofing systems under consideration, such as wooden Ibeams available through RedBuilt [4] and a system designed and sold by HESCO Bastion Ltd. One example of a roofing design is shown in Figure 4.

Figure 4. HESCO company's housing structure using HESCO bastion walls and wooden roof trusses [4].

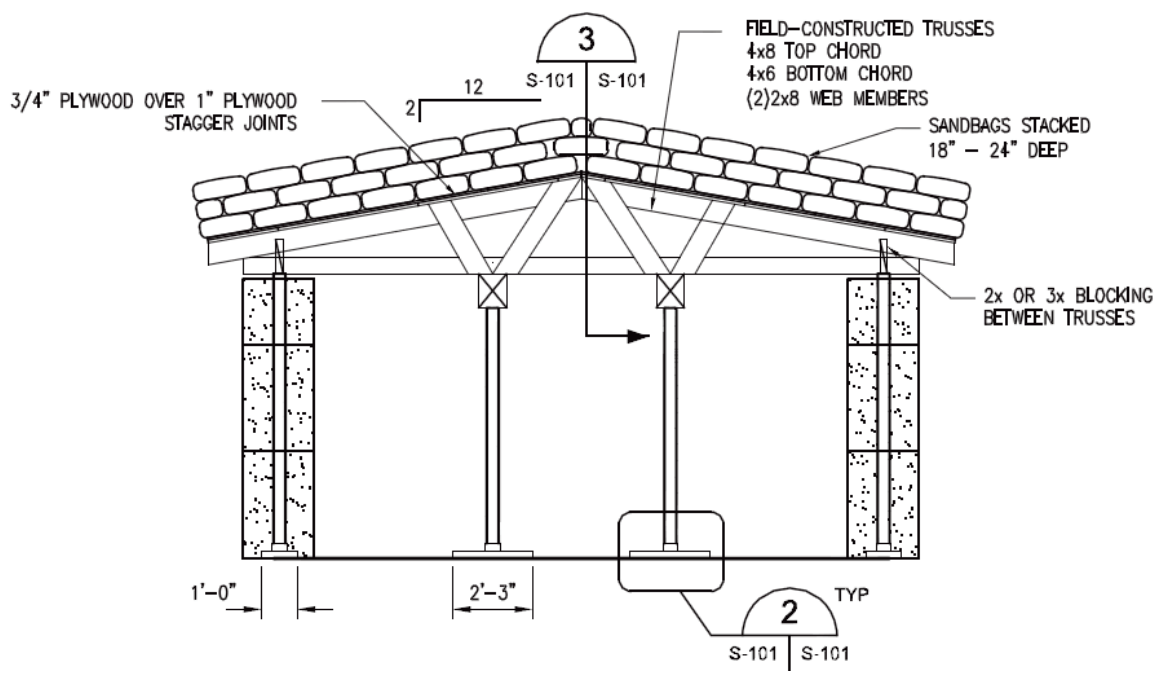

As can be seen in Figure 3, there are three typical boundary conditions of interest for an individual HESCO bastion that is used as part of a structural system. The boundary conditions are defined by the number and location of adjacent HESCO units (see Figure 5).

Figure 5. HESCO unit plan view showing three boundary conditions: (a) one adjacent unit, (b) two adjacent units at corner, and (c) two adjacent units at middle of wall.

a)

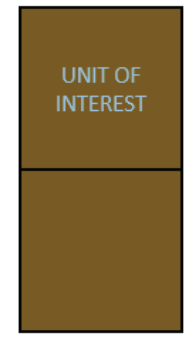

b)

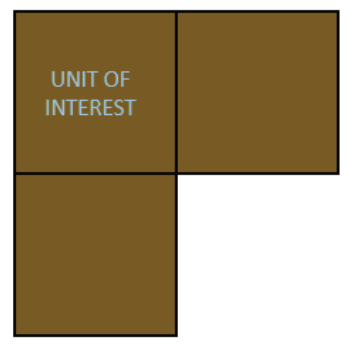

c)

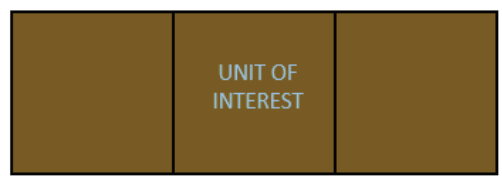


Figure 5a, the end unit in a single, stand-alone wall, is referred to here as an edge cell; Figure $5 \mathrm{~b}$, a corner where two walls meet, is referred to as a corner cell; and Figure 5c, located within the span of the wall, is referred to as an intermediate cell. The boundary conditions are an important consideration as they account for some level of confinement to the unit. That is, the units will have a tendency to bow in the direction where an adjacent unit does not provide confinement. The effect of boundary conditions on HESCO unit bowing is shown in Figure 6.

Figure 6. HESCO bastion bowing: (a) corner cell bows in two directions, (b) edge cell bows in three directions, and (c) intermediate cell bows in two directions.

a)

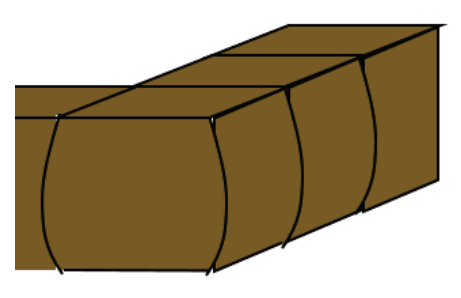

b)

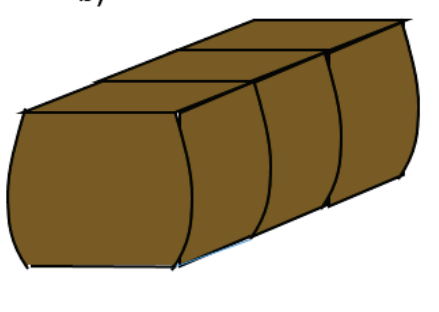

c)

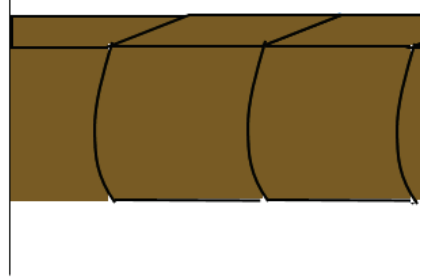

In this study an unconfined unit was tested to represent the worst-case scenario because of the potential for bowing in all four side panels. Test results from an unconfined specimen should be readily applicable to specimens subject to other boundary conditions.

\subsection{Self-weight of materials}

Table 4 shows the self-weight of all filler materials at the base of the HESCO test specimen. (The weight of the HESCO product is not included because it's own weight does not contribute to the load.) The calculations are based on the stated test specimen dimensions and the measured densities from Table 2.

Table 4. Self-weight of HESCO materials.

\begin{tabular}{|l|l|}
\hline Description & Weight $(\mathbf{l b})$ \\
\hline Sand & 11,150 \\
\hline Steel Plate & 1,121 \\
\hline Stub Column & 200 \\
\hline TOTAL Self-Weight & 12,471 \\
\hline
\end{tabular}


Thus, the weight of the designed roof on each HESCO unit-8,772 lb (see previous section)-plus the self-weight of only the sand (11,150 lb) combines for a total of $19,922 \mathrm{lb}$. 


\section{Testing Program}

\subsection{Testing facility}

ERDC-CERL was chosen as the test facility in order to make use of its concrete strong-floor and hydraulic actuator system. For the desired tests, it was necessary for the HESCO bastion unit to be secured to this floor in order to resist lateral movement and support the application of normal loading.

\subsection{Specimen mounting}

A concrete pad purpose-designed for this study was constructed on the strong-floor (Figure 7) A threaded DYWIDAG ${ }^{*}$ bar was run vertically through the concrete strong-floor and passed through a center aperture in the concrete pad as part of the load-application mechanism. The unfilled HESCO test specimen (Figure 8) was then placed on top of the prepared pad. Figure 9 shows the interior of the HESCO specimen with the rod in place.

Figure 7. Concrete pad on strong-floor.

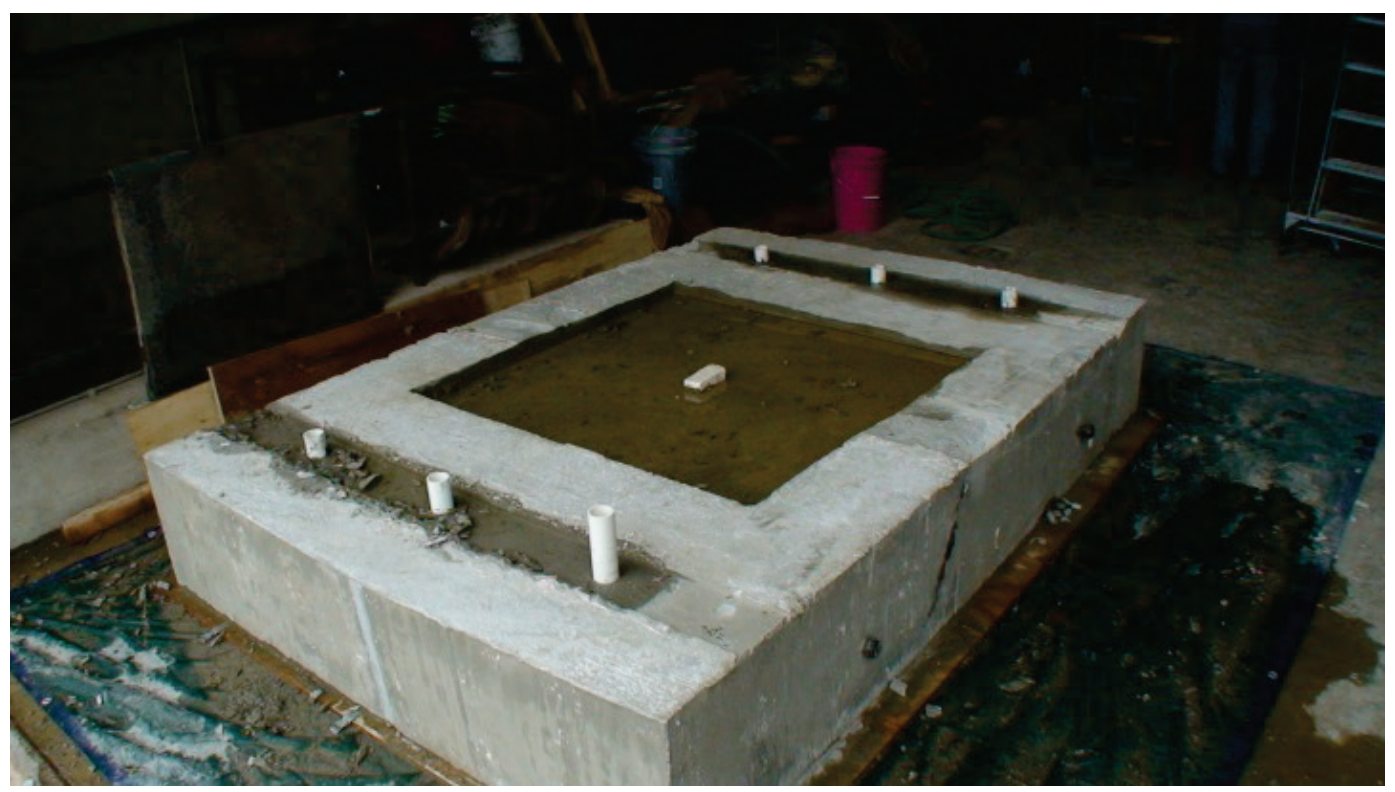

* DYWIDAG is a trademark of DYWIDAG-Systems International. 
Figure 8. Exterior of unfilled HESCO bastion.

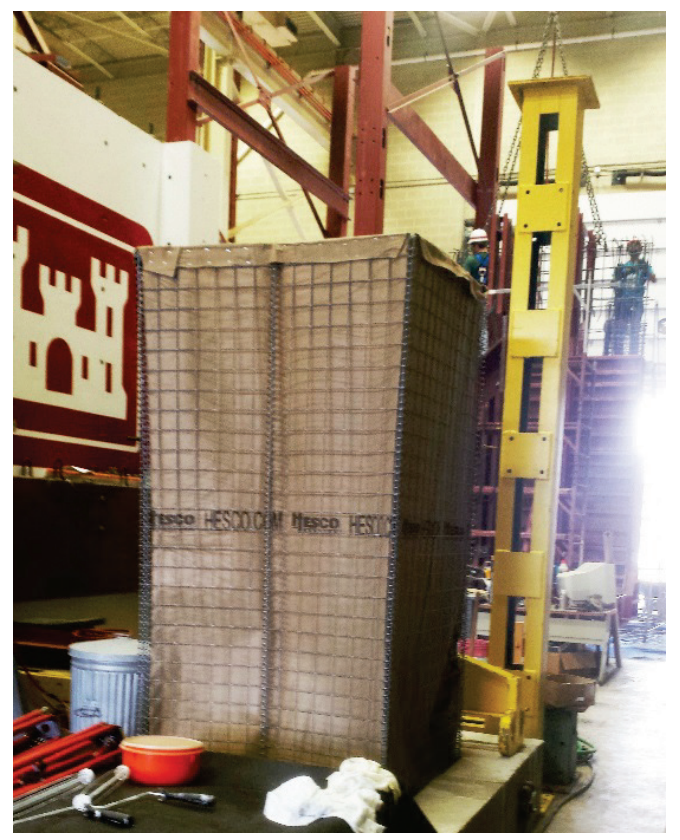

Figure 9. Interior of unfilled HESCO bastion showing threaded rod vertically penetrating the concrete pad.

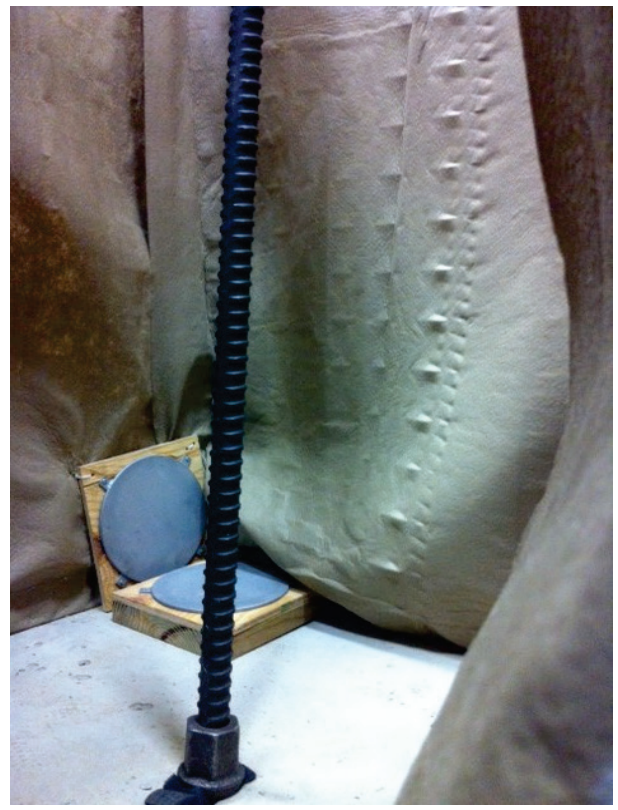

A special assembly consisting of a square load-transfer frame and a slotted, hemispherical bushing was installed on the threaded rod to create a pinned connection that can pivot to accommodate swaying of the specimen while maintaining a normal loading condition (Figure 10 and Figure 11). The specimen was then filled with the sand specified in section 2.2. 
Figure 10. Photograph of special load-transfer assembly used in testing program.

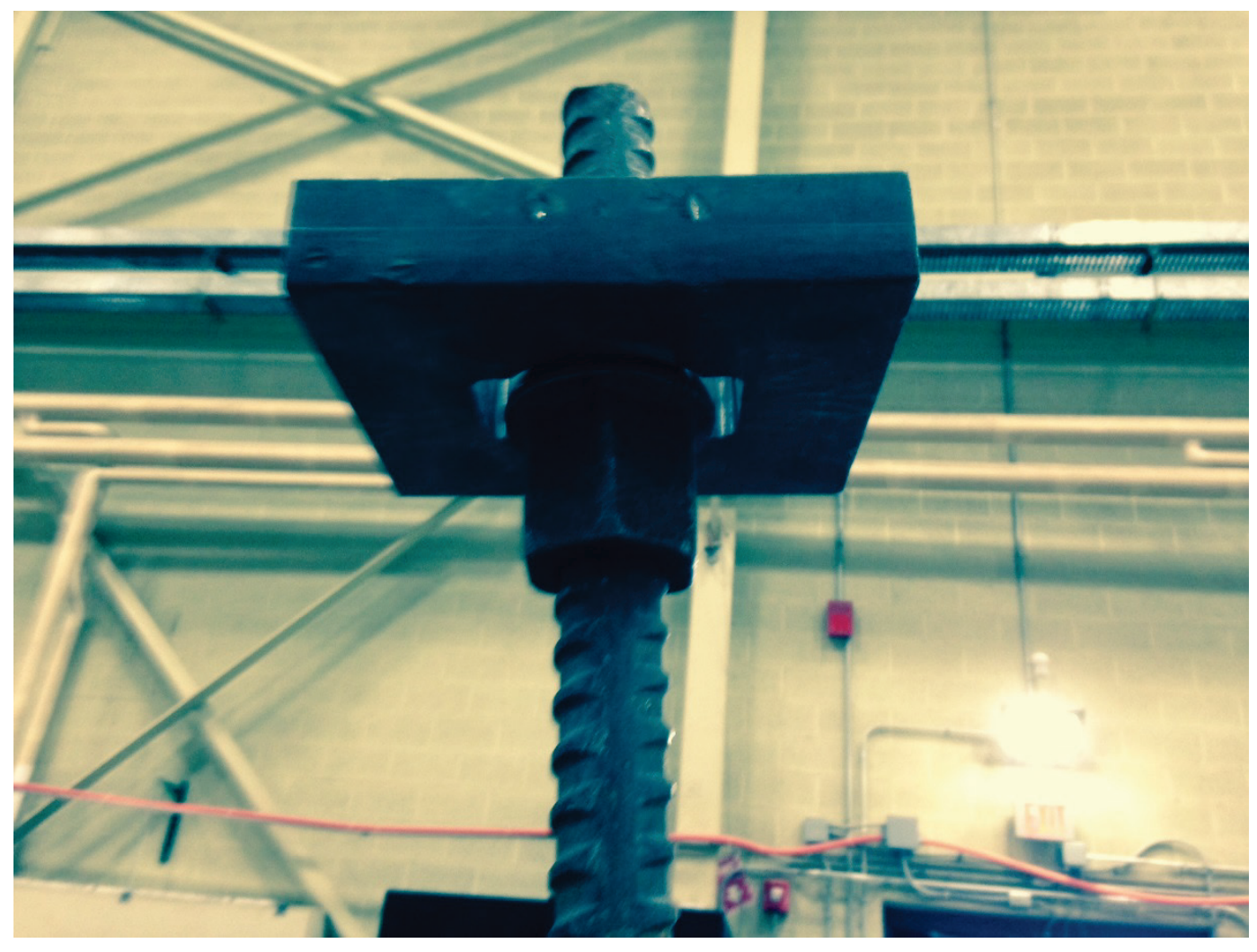

Figure 11. Detail showing threaded rod connection with hemispherical bushing to allow rotation of the threaded rod.
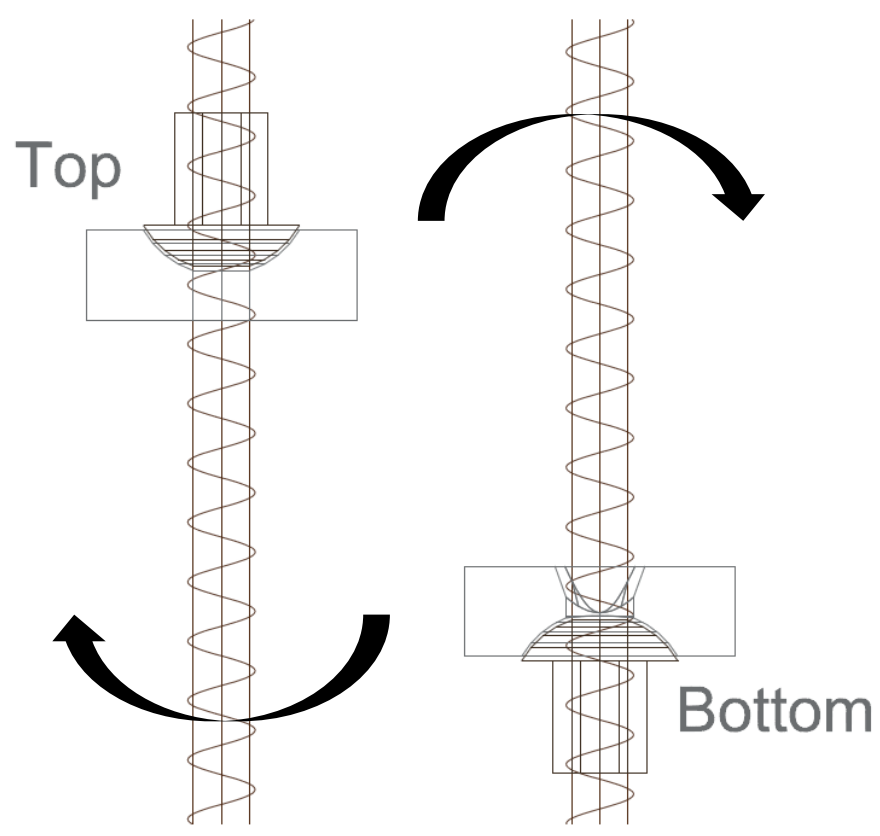


\subsection{Loading apparatus}

A steel-channel frame was erected around the location to support the lateral-load-applying actuator and instrumentation (Figure 12). A steel plate weighing $1,121 \mathrm{lb}$ was fabricated to be placed on top of the HESCO bastion with an attachment point for the horizontal actuator to be attached to the specimen (Figure 13). An elevation view drawing of the concrete pad, specimen, and horizontal actuator is shown in Figure 14. A 100 kip actuator with a $12 \mathrm{in.} \mathrm{stroke} \mathrm{was} \mathrm{attached} \mathrm{to} \mathrm{a} \mathrm{reaction} \mathrm{wall} \mathrm{and} \mathrm{bolted} \mathrm{to} \mathrm{the} \mathrm{steel}$ plate on top of the specimen (Figure 15). The steel plate was slotted to force any shear load to be resisted exclusively by the sand and not the threaded rod. A stub column weighing $200 \mathrm{lb}$ was placed on top of the specimen to allow a hydraulic jack to be secured to the threaded rod by means of a steel plate and a nut. The hydraulic jack used was a BVA Hydraulics P100o hand pump with a 10,000 psi capacity. The hand pump was further connected to a BVA HC10003T hydraulic cylinder with 3 in. stroke and 100 ton capacity. A load cell was placed between the hydraulic cylinder and the steel plate.

Figure 12. Isometric drawing of test setup (NW view).

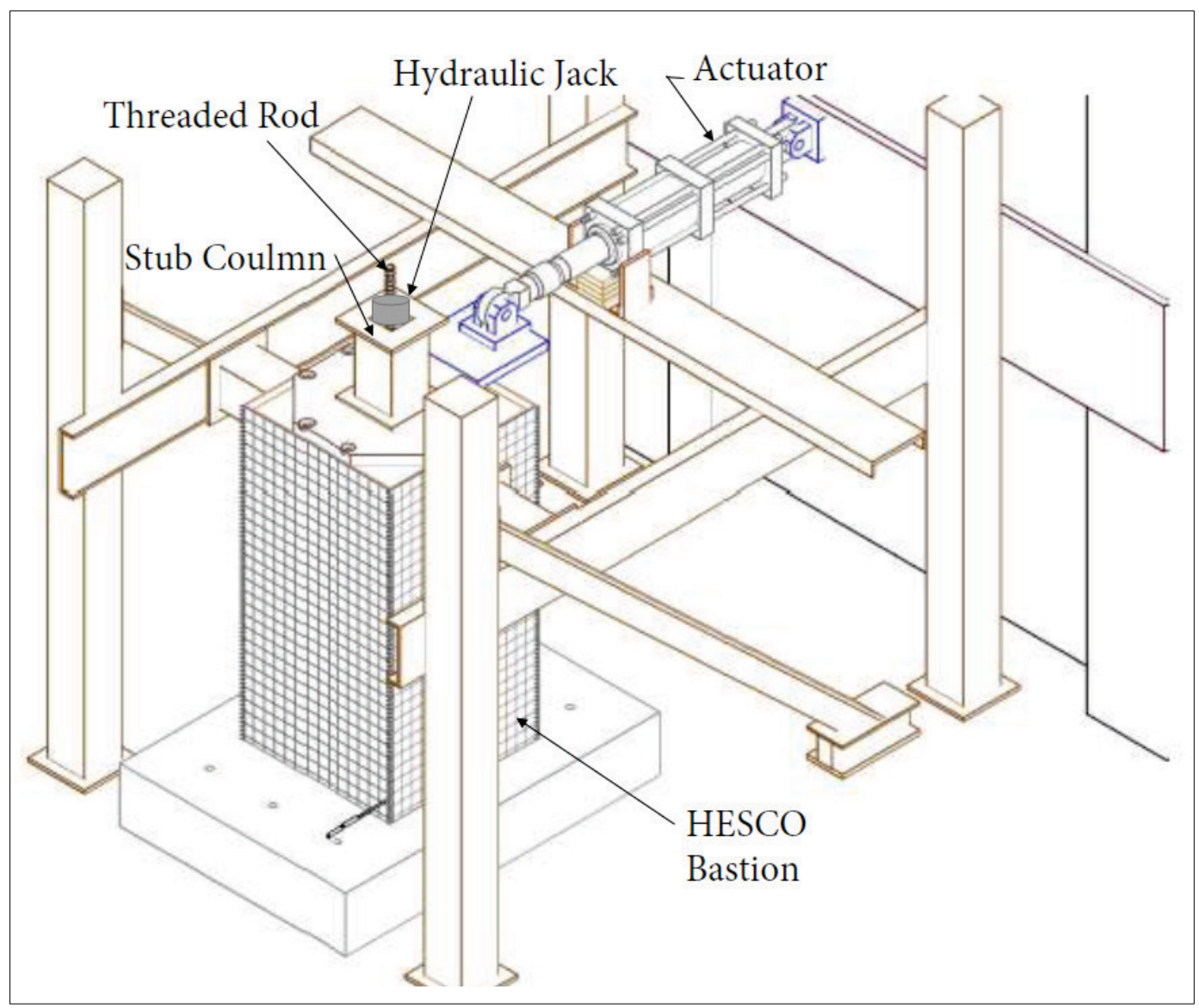


Figure 13. Drawing of steel plate for applying normal loading to top of test specimen, showing attachment point for horizontal actuator and center slot for threaded rod.

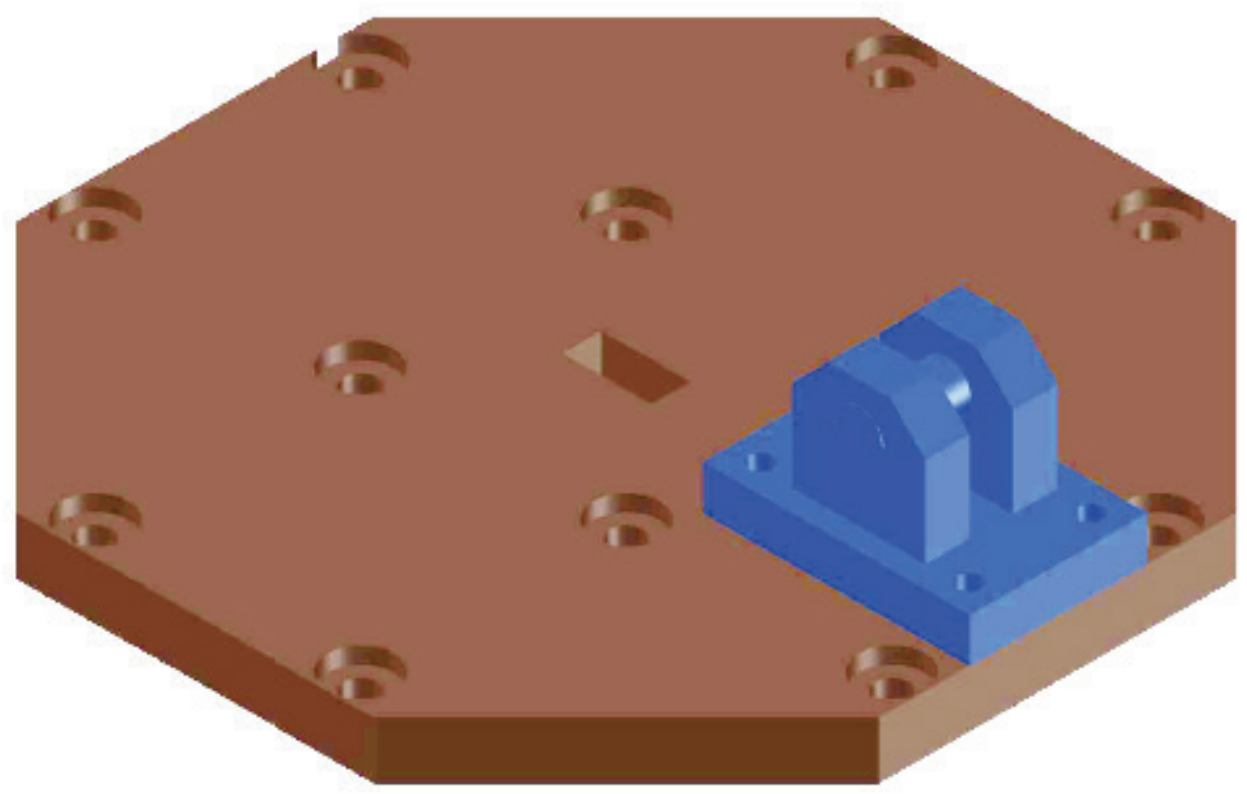

Figure 14. Dimensioned drawing of test setup (north elevation view).

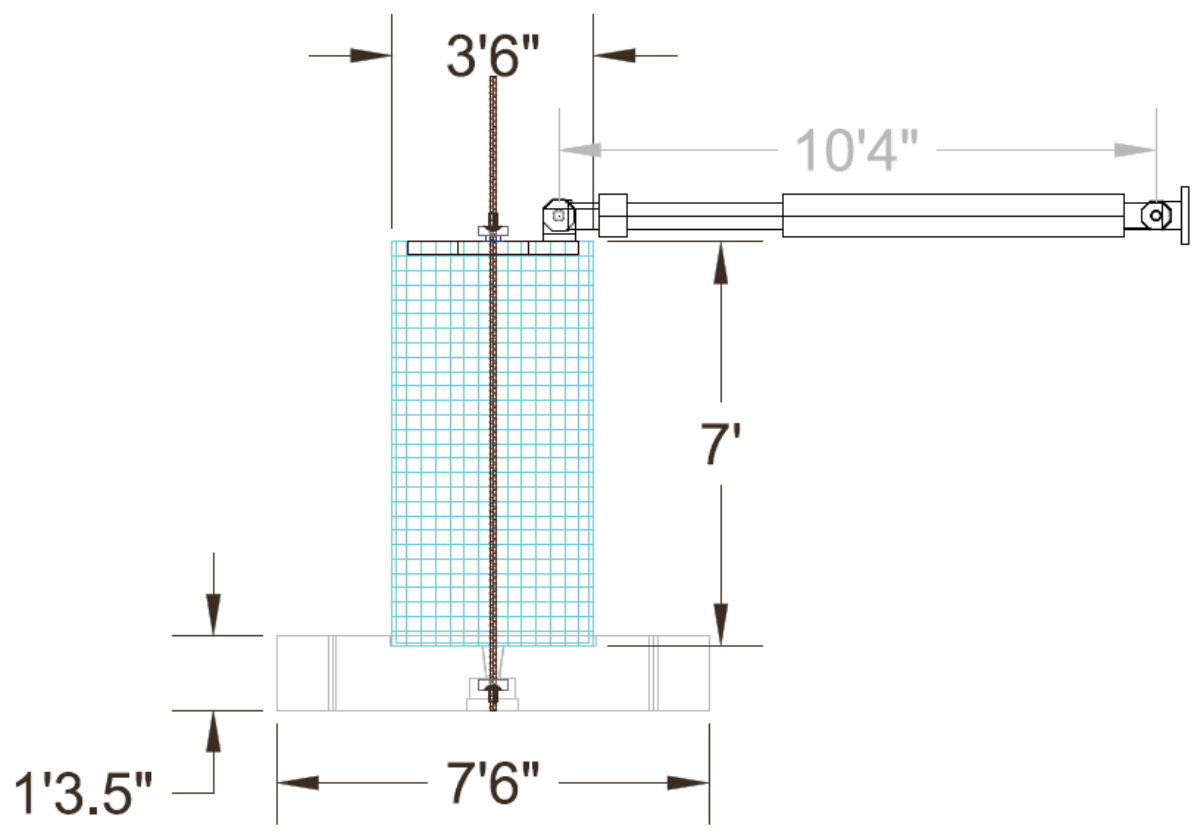


Figure 15. Laboratory photograph showing the connection between the reaction wall and the steel plate atop the HESCO bastion.

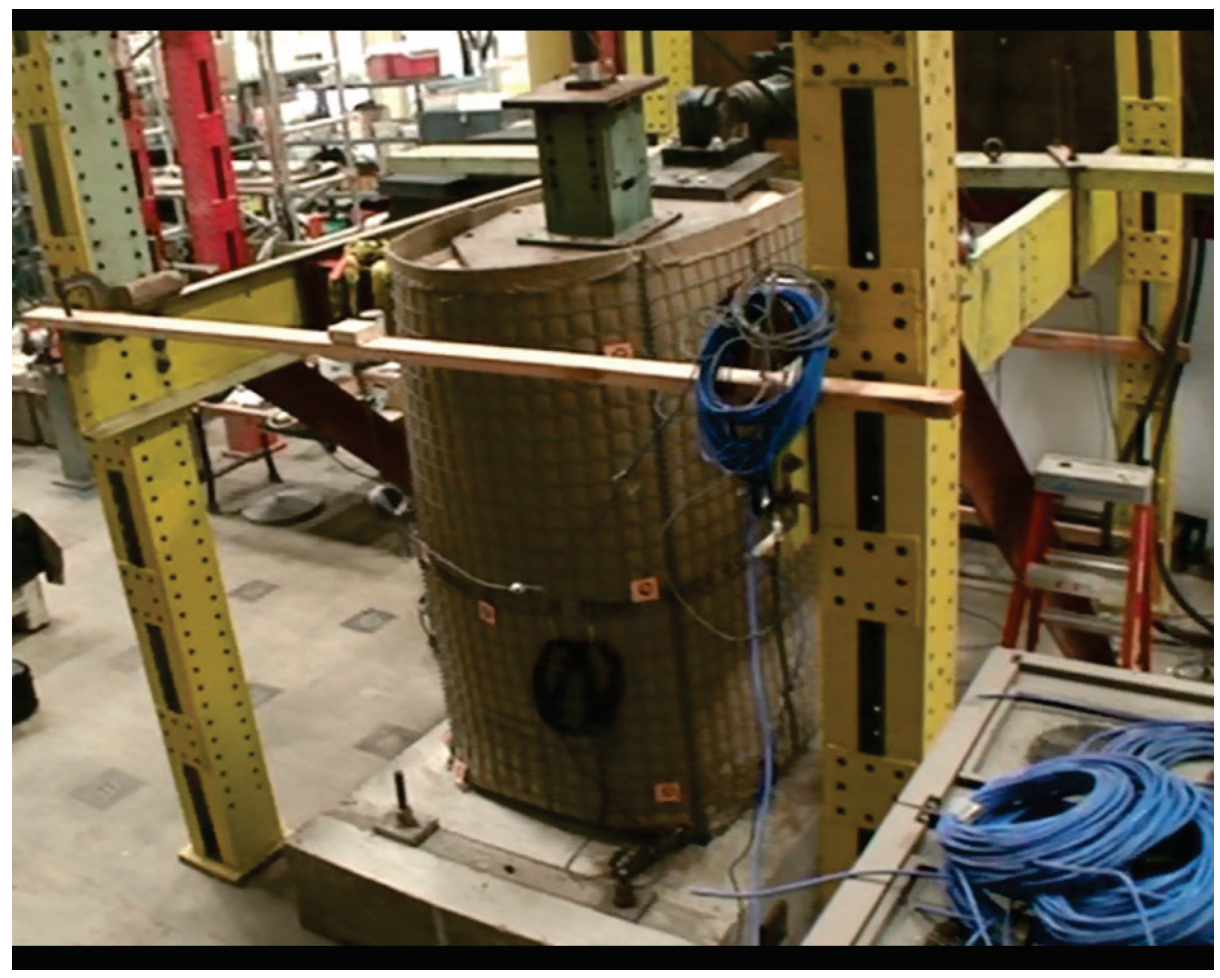

\subsection{Instrumentation}

Two types of instrumentation were employed during the tests to measure displacements and applied loads on the specimen: string potentiometers and strain-gage based load cells.

\subsubsection{String potentiometers}

Celesco Model PT8101-0020-211 string potentiometers were used to measure the absolute displacement at the point of attachment. These potentiometers employ a spring-loaded precision rotary potentiometer with a flexible steel cable wrapped around the potentiometer shaft. The other end of the cable is attached to the point where displacement is to be measured. When displacement occurs, the cable motion rotates the shaft causing a change in resistance. This model of transducers has a cable length of 20 in., which was deemed acceptable because the testing protocol required no more than \pm 6 in. of displacement. These transducers were secured to the steel channel frame and attached to the specimen at predetermined locations. They were then connected to a Pacific Instruments 6000 series dataacquisition and signal -conditioning system using their 6033-3 DC signal- 
conditioning boards, which provide direct current (DC) power, electrical balancing, and digital amplification.

\subsubsection{Load cells}

A load cell was fabricated using a thick-walled aluminum cylinder sized to slide over the threaded DYWIDAG bar. Strain gages were attached to the cylinder in a full Wheatstone bridge configuration. When a voltage is applied to a circuit in this configuration, the voltage change across the circuit can be measured. When a load is applied to the cylinder, the resistance of the strain gages changes, and thus so does the change in voltage across the circuit. The difference in the measured voltage can then be used as a proxy to measure the applied load. To accomplish this, the load cell was calibrated by placing it in a 100 kip load frame and applying a 5 volt signal; and the change in voltage was measured at increments of $1000 \mathrm{lb}$. By doing this, a gage factor of $0.2 \mathrm{mv} / \mathrm{v} / 1000 \mathrm{lb}$ was measured. This load cell was then placed between the hydraulic jack and the specimen to measure the applied normal load. The output was measured by connecting to the Pacific Instruments 6000 series data acquisition system using the 6033-3 DC signal-conditioning boards.

The lateral load was measured by the load cell already connected in-line with the actuator. This load was measured by the Instron 8800 actuator controller in conjunction with the Instron Console software. The actuator load was also connected to the Pacific Instruments 6000 system to allow for simultaneous sampling with all other instruments.

\subsection{Channel notation}

Figure 16 shows the instrumentation layout for the test specimen, and Table 5 indicates the measurement to which each channel was dedicated. 
Figure 16. Instrumentation layout and channel notation.

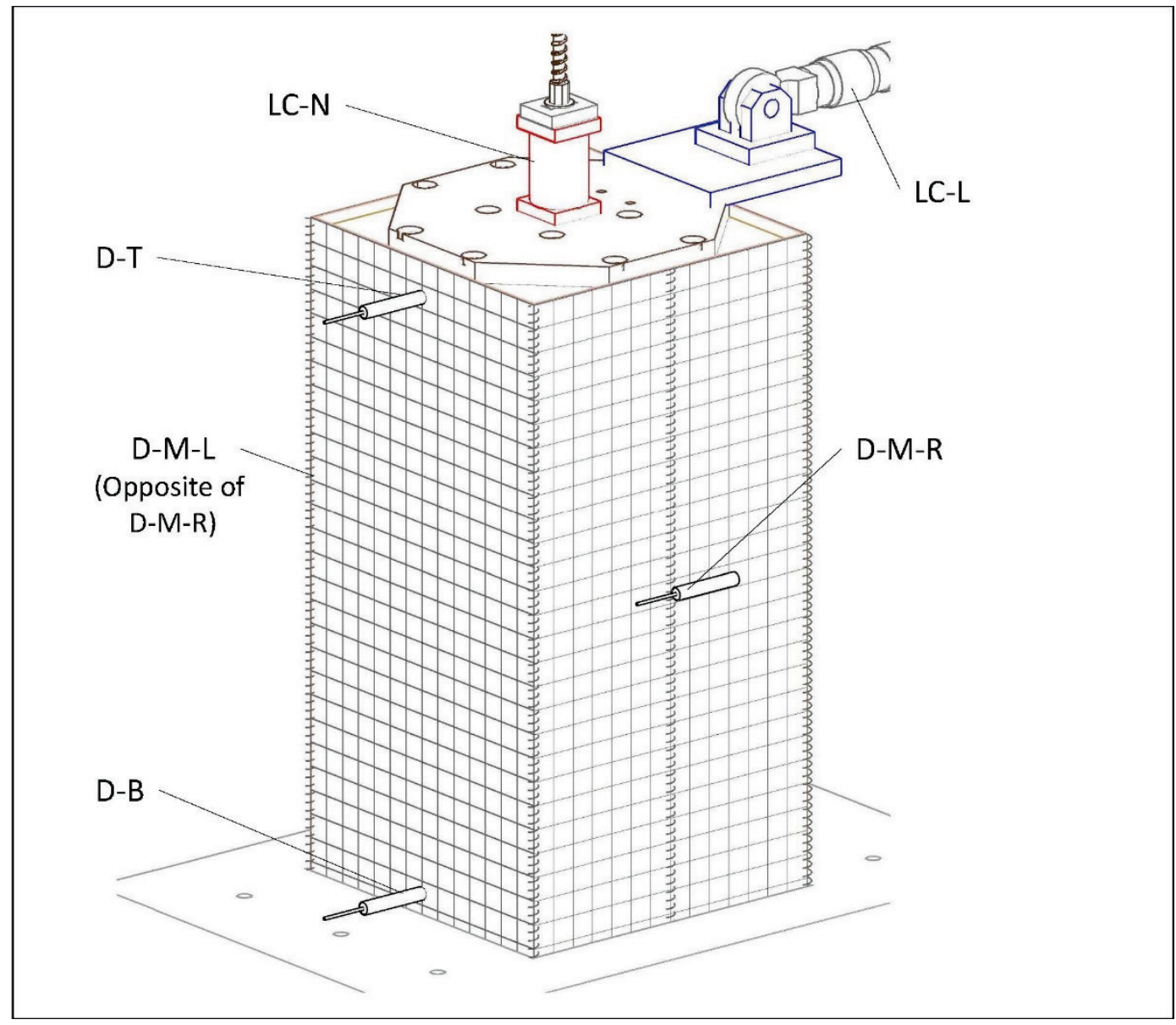

Table 5. Channel designation and use.

\begin{tabular}{|l|l|}
\hline Channel Designation & Description \\
\hline D-M-L & String pot: Measures Left Mid-height Displacement \\
\hline D-T & String pot: Measures Top Displacement \\
\hline D-B & String pot: Measure Bottom Displacement \\
\hline D-M-R & String pot: Measures Right Mid-height Displacement \\
\hline LC-N & Load Cell: Measures Applied Normal Load \\
\hline LC-L & Load Cell: Measures Applied Lateral Load \\
\hline
\end{tabular}

\subsection{Selection of cyclic loading protocol}

The loading procedure described here follows the protocols outlined in ASTM E2126-11: Method B [5], a displacement-controlled loading procedure grouped in phases at incrementally increasing displacement levels. 
The procedure for this study required a combination of normal and lateral loads to ensure that the laboratory environment best models the field environment. At each displacement level the normal load was increased accordingly. The self-weight of one filled individual HESCO unit is approximately $11,150 \mathrm{lb}$ as indicated in Table 2 . The roof load, as based on the design presented in Appendix A, was 8,772 lb per HESCO unit, imposing a total design load of 19,922 lb. The hydraulic jack described in section 3.3 was used to simulate the roof load and provide increasing levels of normal load to the HESCO bastion.

Figure 17 provides a visual plot of the nominal lateral loading cycle protocol. The loading sequence began with a normal load of 17,500 kips with displacement of $2 \mathrm{in}$. After three cycles the normal load as increased to 25,000 kips and the displacement was increased to 4 in. for three more cycles. Next, the normal load as decreased to 24,000 kips and the displacement was increase to $6 \mathrm{in}$. for six more cycles. To accomplish this protocol, the horizontal actuator was paused between targeted displacements to allow for the jack to be pumped to the targeted normal load.

Figure 17. HESCO bastion lateral displacement cycle.

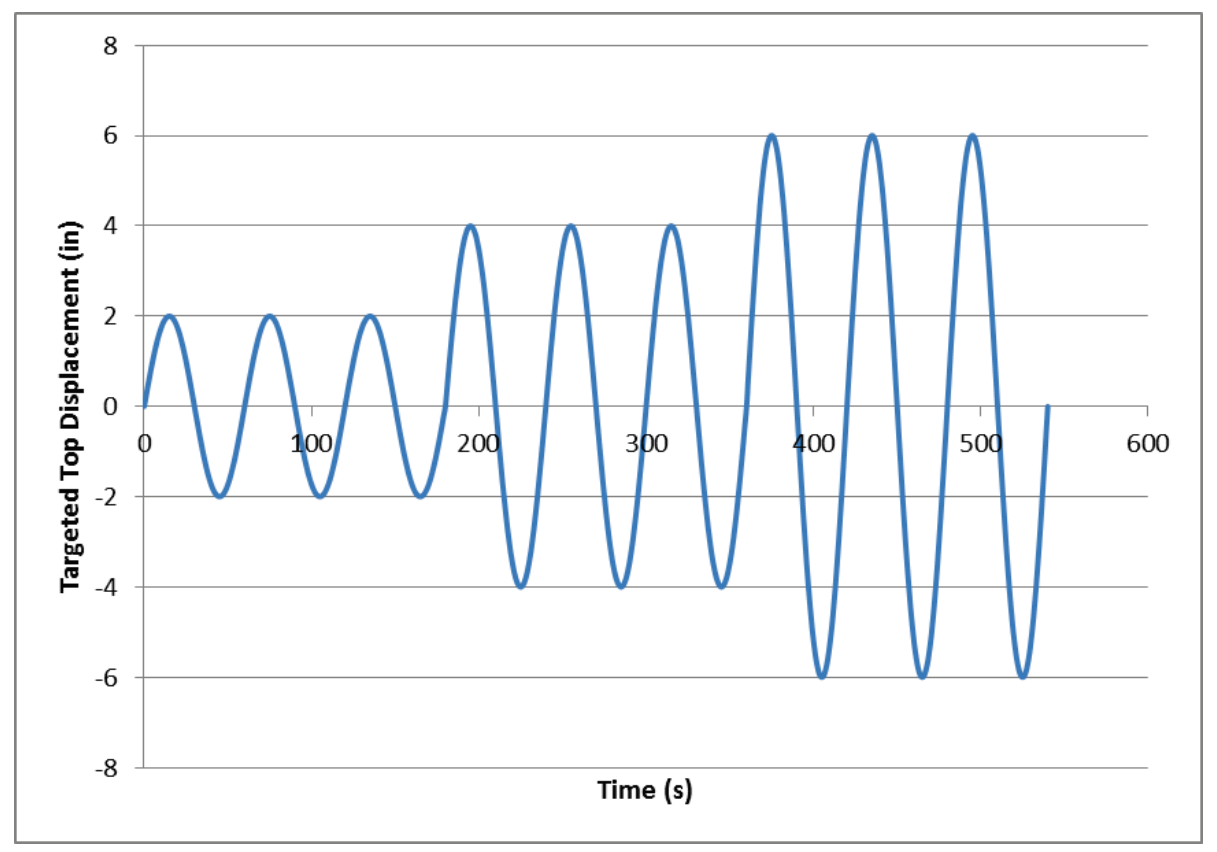




\section{Results}

\subsection{Normal loading}

Table 6 shows the load applied by the hydraulic pump before each run.

The table also shows the total normal load on the test specimen, which includes the applied normal load and the total self-weight from Table 4.

Table 6. Applied normal load for each test run.

\begin{tabular}{|c|c|c|}
\hline Run & Applied Normal Load (lb) & Total Normal Load (lb) \\
\hline 1 & 5,776 & 18,247 \\
\hline 2 & 13,406 & 25,877 \\
\hline 3 & 15,161 & 27,632 \\
\hline 4 & 11,956 & 24,427 \\
\hline
\end{tabular}

\subsection{Top displacement}

The target displacement values for the top of the specimen for each of the four runs were 2 in., 4 in., and two runs of 6 in. Due to the geometry limitations of the test apparatus, the actual displacement at the top of the HESCO specimen was slightly smaller, as summarized in Figure 18 through Figure 21.

Figure 18. Run 1 measured top displacement ( 2 in. targeted).

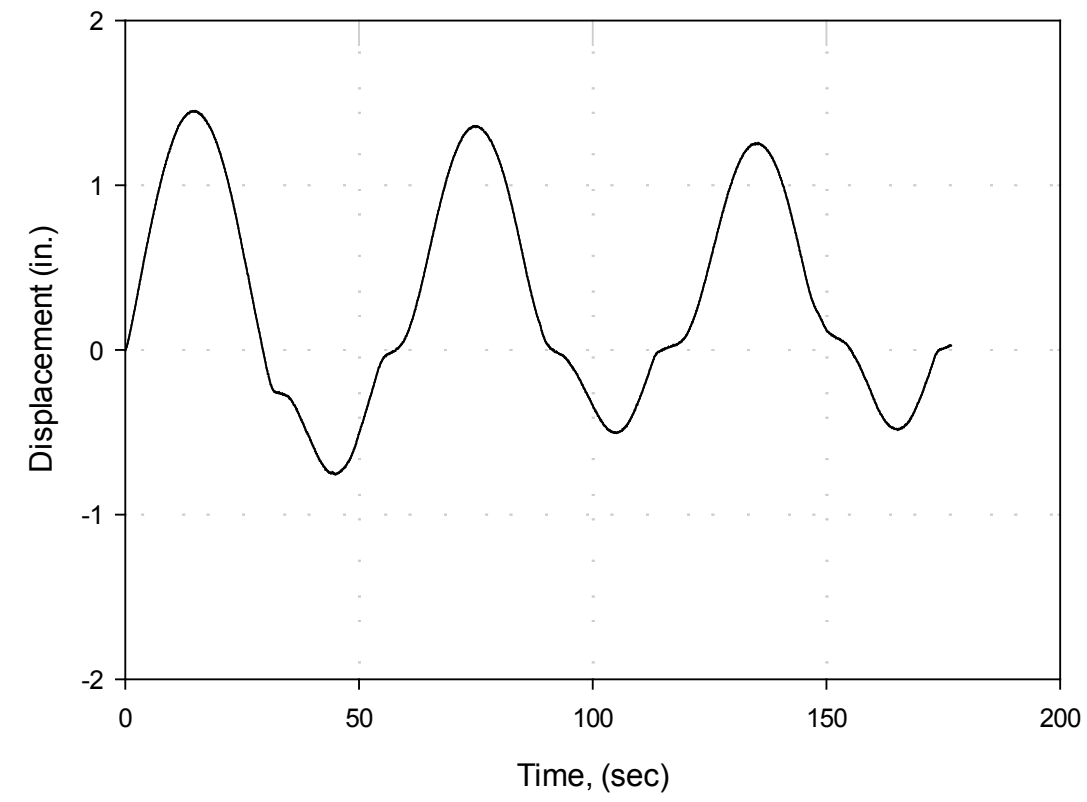


Figure 19. Run 2 measured top displacement (4 in. targeted).

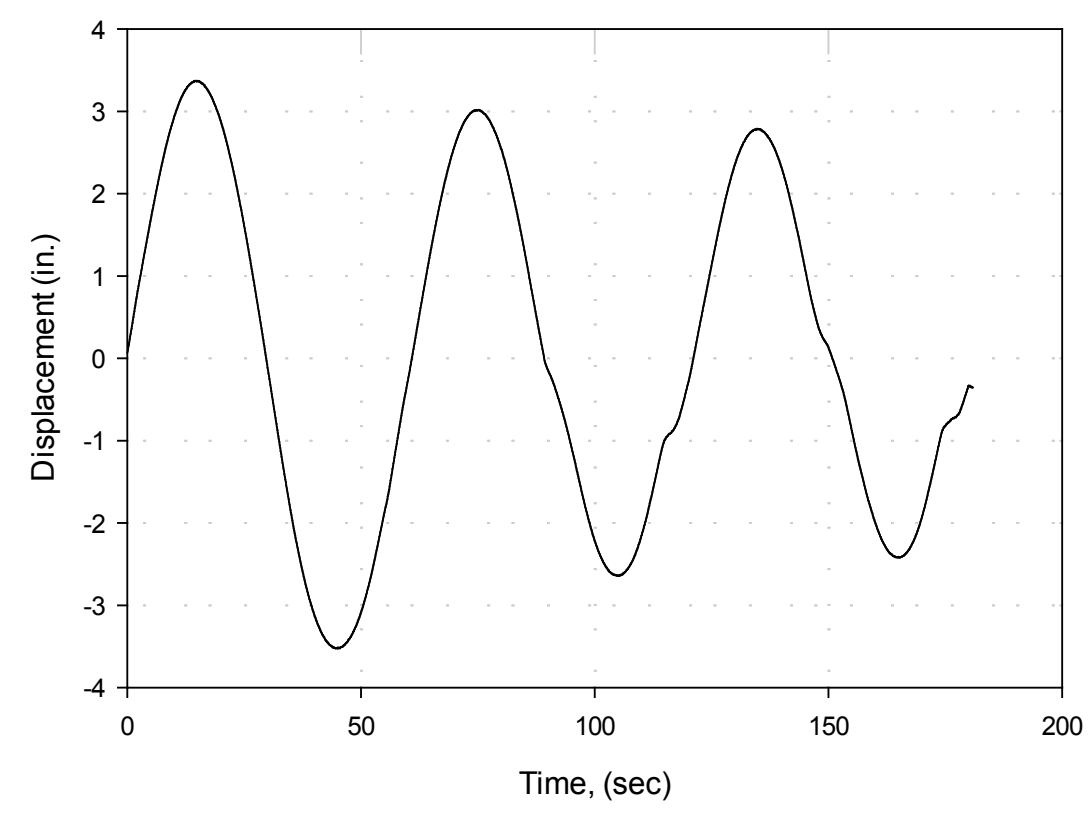

Figure 20. Run 3 measured top displacement (6 in. targeted).

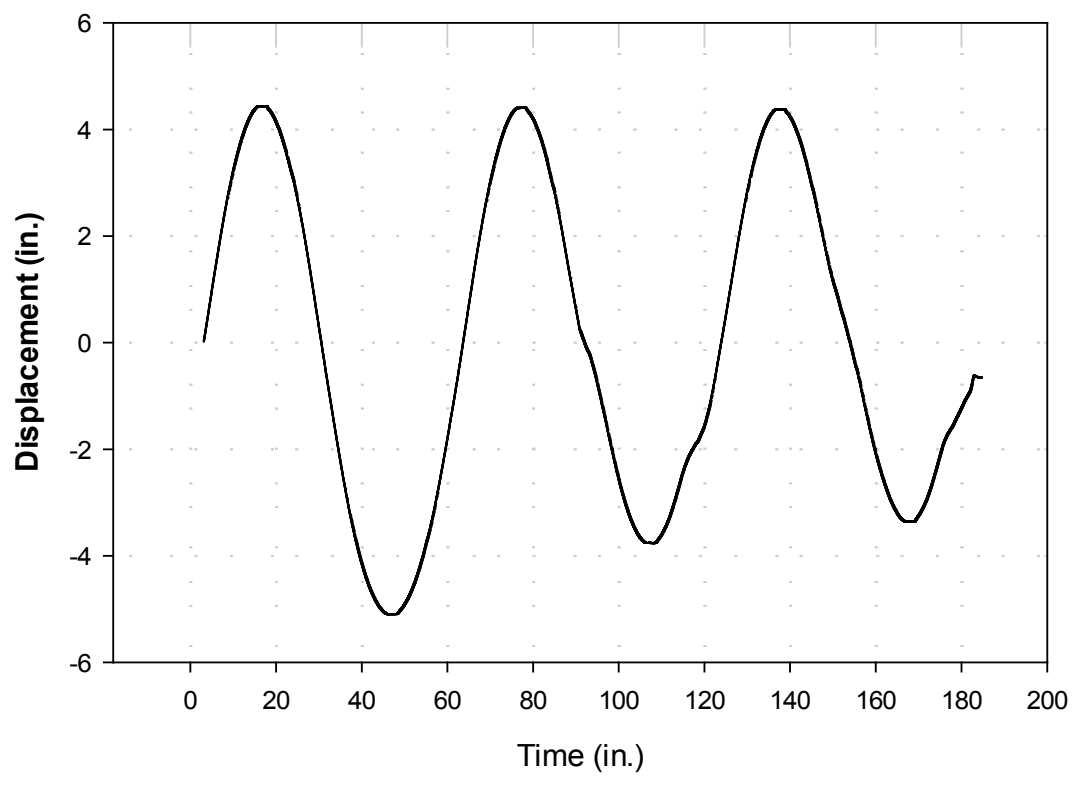


Figure 21. Run 4 measured top displacement (6 in. targeted).

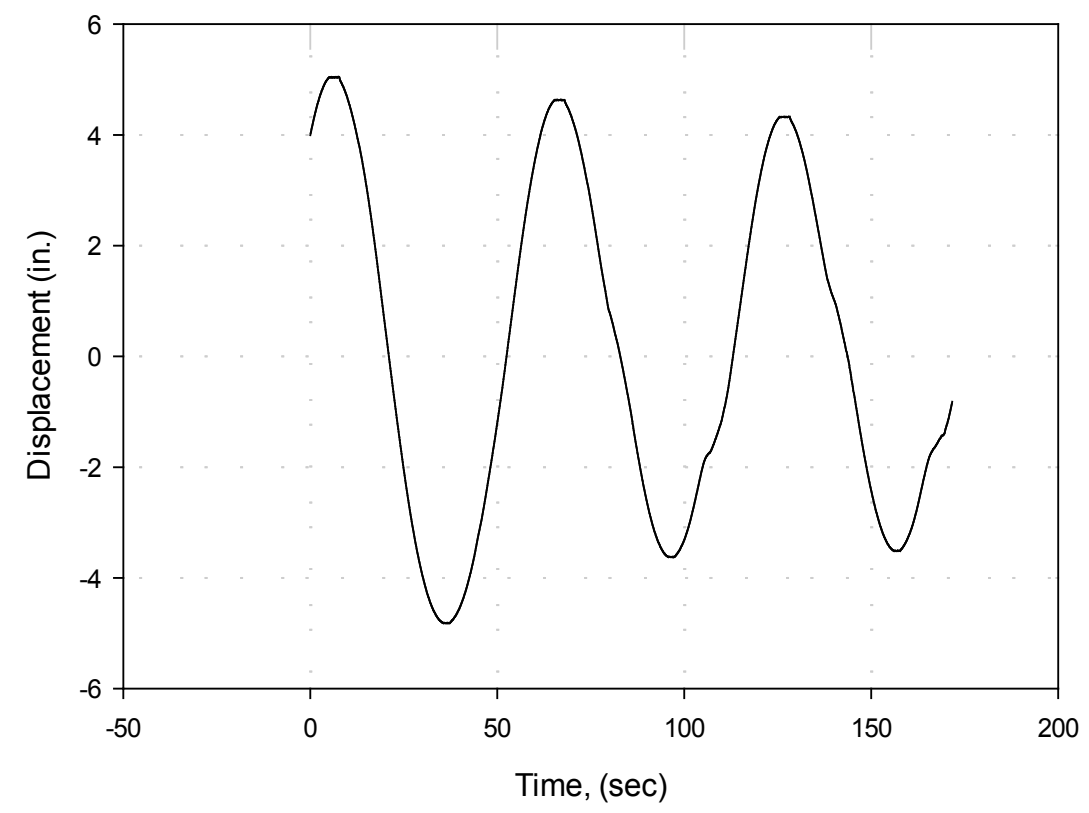

The start of Run 4 began at a displacement of 4 in., because the HESCO bastion was not brought to the vertical position before this run began. Also, what becomes apparent is that the lateral displacement of the top of the HESCO bastion gradually decreases during each run. This phenomenon would indicate that the steel normal loading plate began to lose its bearing on the top of the HESCO bastion. (This result is consistent with the general decrease in normal load throughout the course of the run as described in section 5.3).

\subsection{Investigation of accidental torsion}

To prevent torsion of the entire specimen, string potentiometers were attached on both sides of the HESCO unit at mid-height to measure the relative displacement on each side. The results are shown in Figure 22 through Figure 25 . 
Figure 22. Run 1 measured displacement at mid-height.

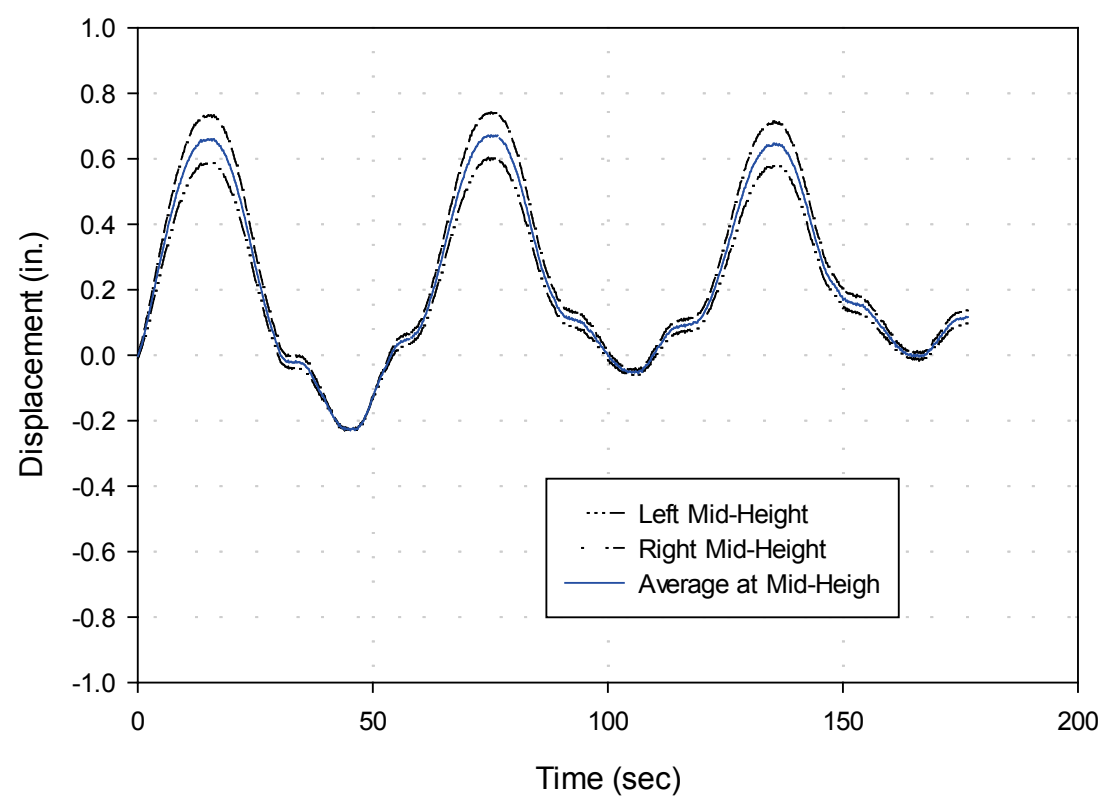

Figure 23. Run 2 measured displacement at mid-height.

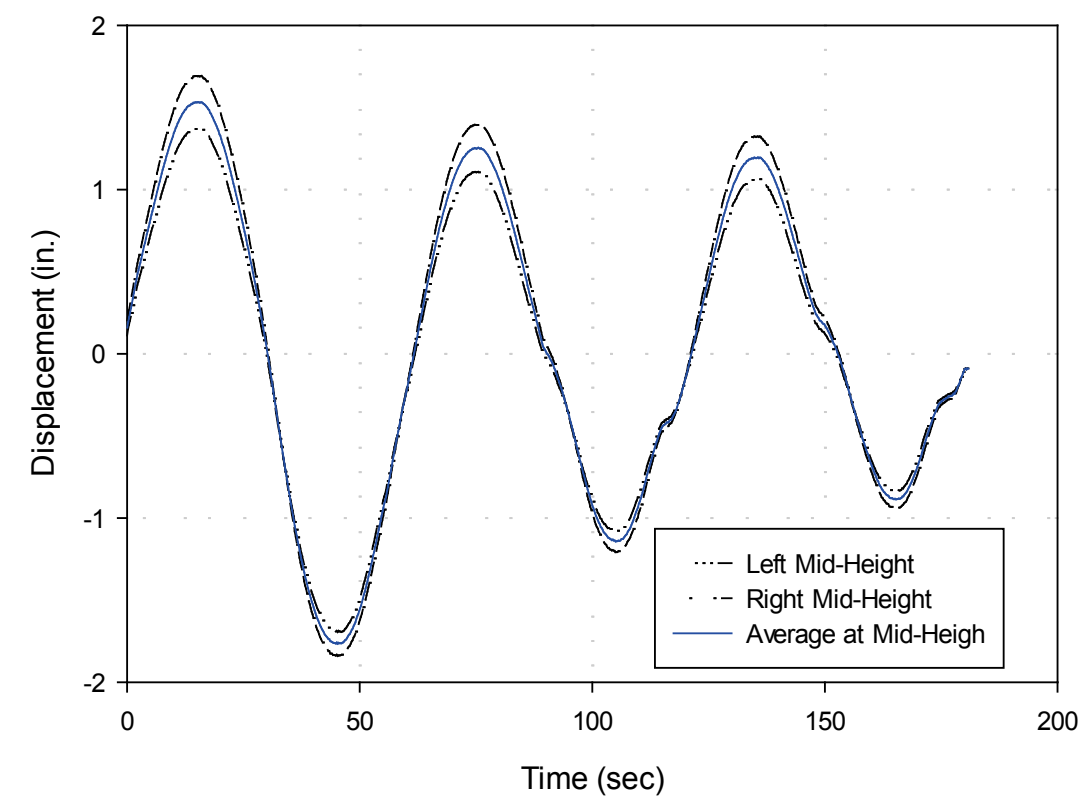


Figure 24. Run 3 measured displacement at mid-height.

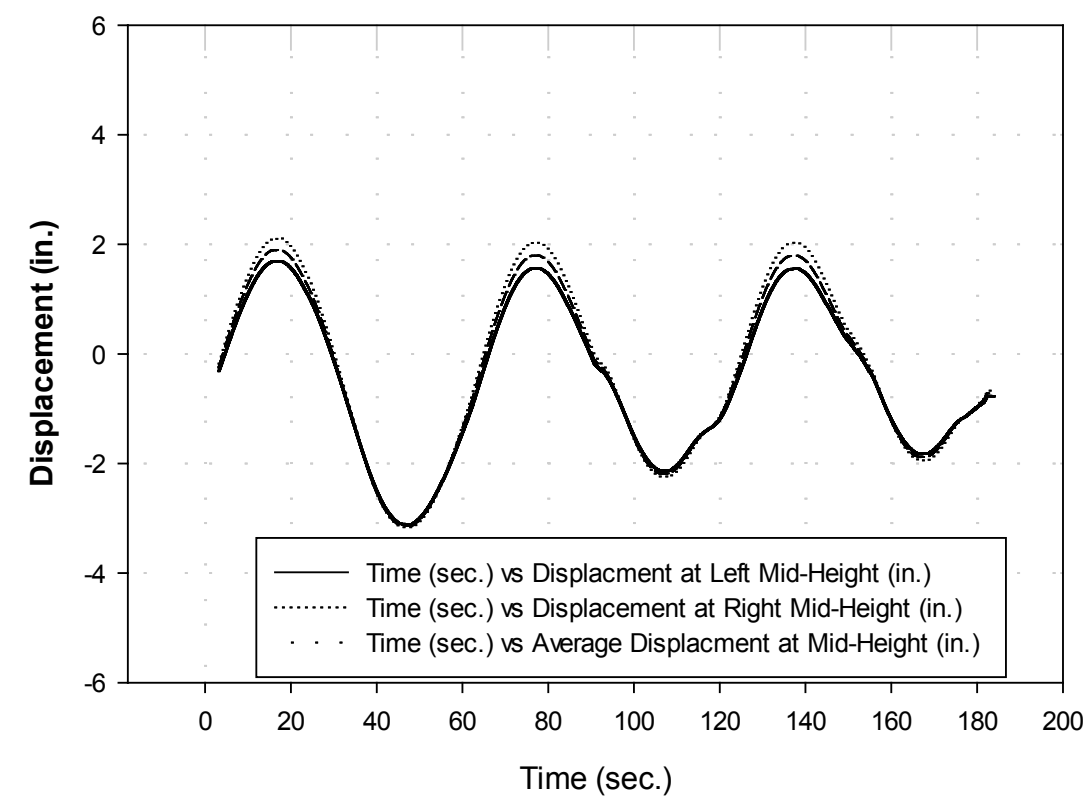

Figure 25. Run 4 measured displacement at mid-height.

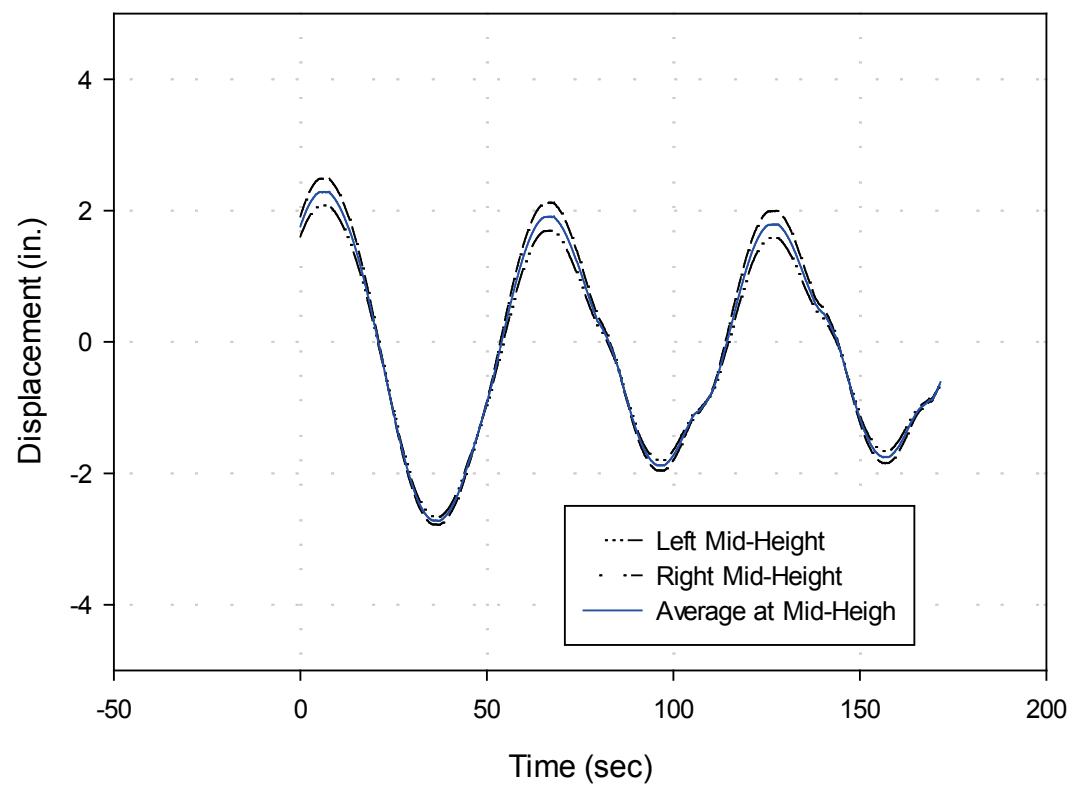

As shown in Figure 22, there was approximately a quarter-inch difference between the left and right sides of the specimen during Run 1. Since the specimen is 42 in. wide, this difference represents a 0.34 degree twist, and is considered negligible torsion. 


\subsection{Measured load versus time}

Figure 26 through Figure 29 show the applied lateral and normal loads as measured versus time. Run 1 began with a normal load of 17,500 kips. Run 2 began with a normal load of 25,00o kips, and runs 3 and 4 began with a normal load of 24,00o kips. During the course of each run, the measured load in the sand generally decreased, with local maxima occurring during the maximum amplitude of the lateral load (maximum lateral displacement). The lateral load measured during each run oscillated about the zero-load point and also decreased in peak amplitude throughout the run. The decrease in lateral load needed to displace the HECSO bastion is related to the decrease in normal load. As the normal load decreased, the HESCO bastion unit became less stiff, allowing lateral displacement under less of a lateral load. This phenomenon could also indicate a general weakening of the HESCO bastion and/or the formation of a plastic hinge near the base of the unit.

Figure 26. Run 1 measured load versus time.

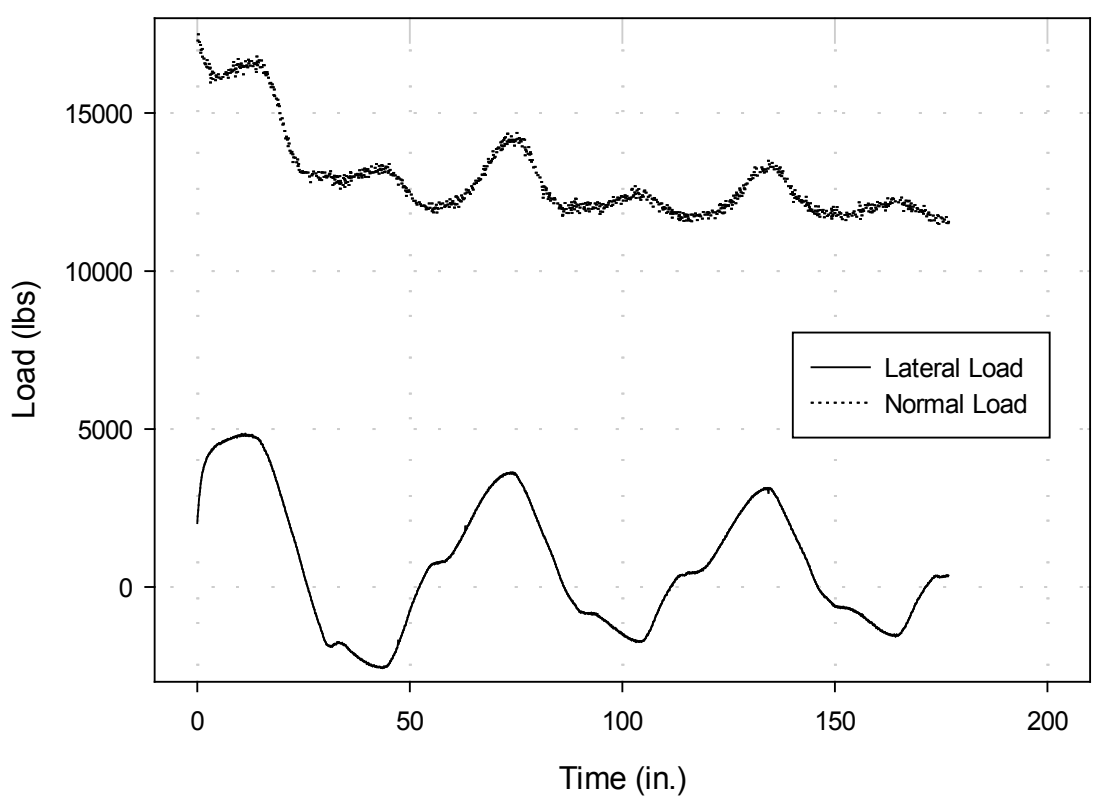


Figure 27. Run 2 measured load versus time.

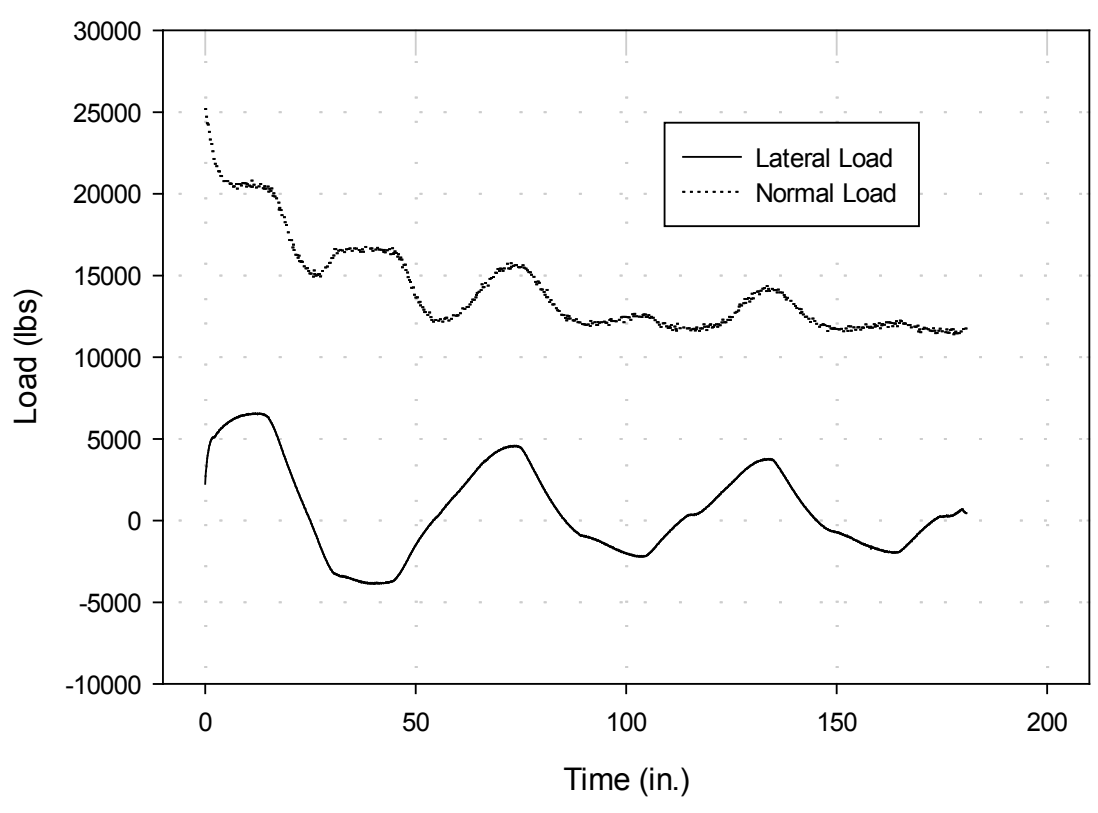

Figure 28. Run 3 measured load versus time.

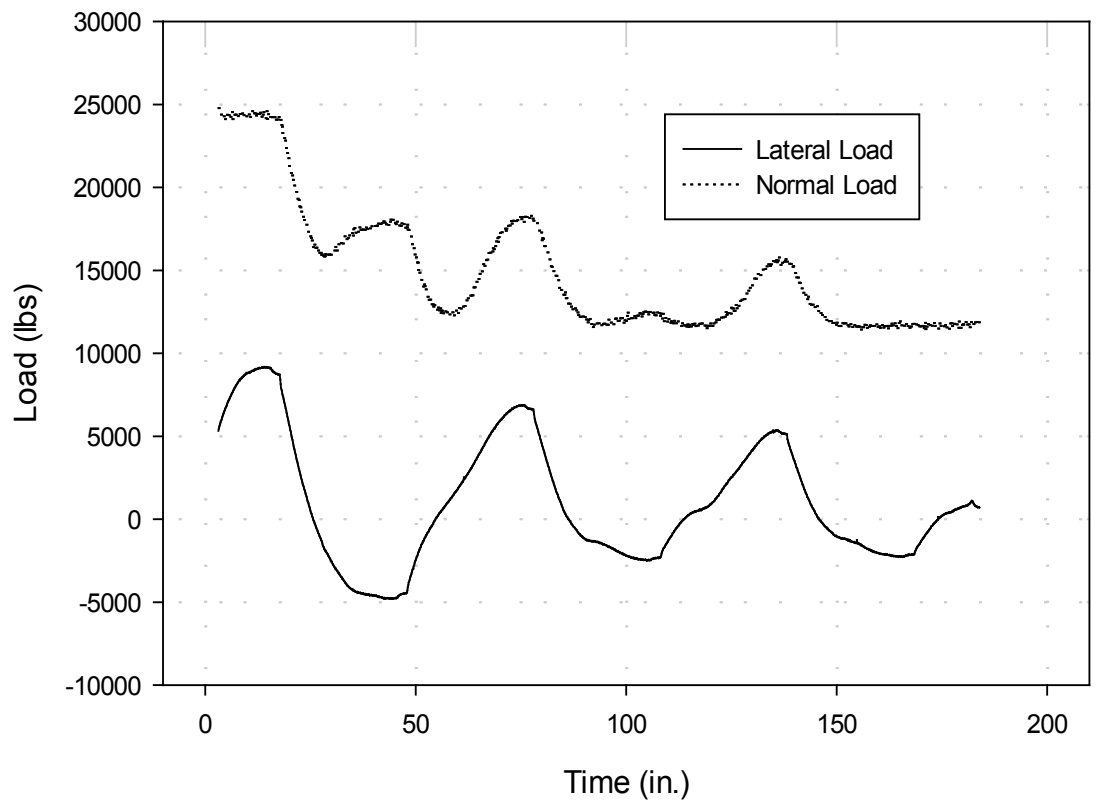


Figure 29. Run 4 measured load versus time.

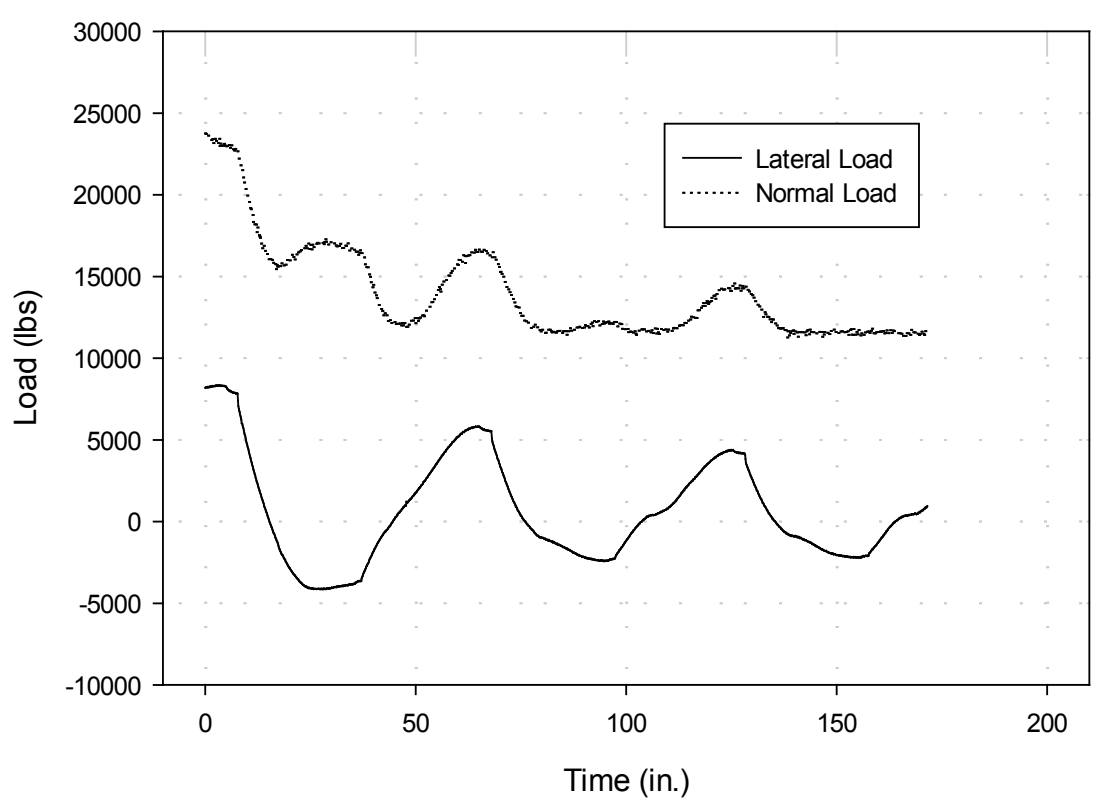

\subsection{Hysteresis}

Lateral load was plotted against maximum displacement to determine specimen energy-dissipation capacity (Figure 30 through Figure 33). A red-dashed backbone curve was superimposed over the hysteresis loops.

Figure 30. Run 1 hysteresis results.

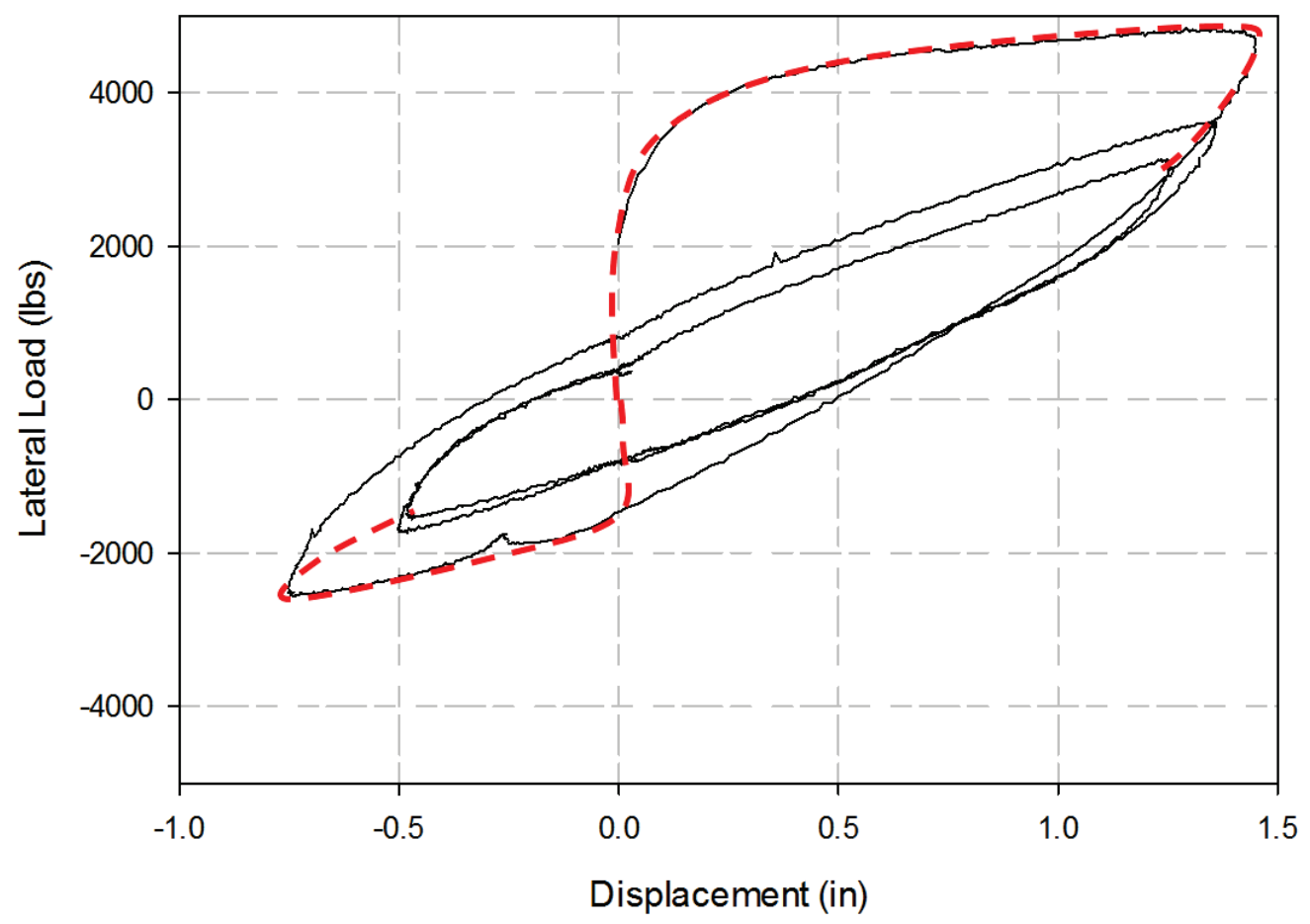


Figure 31. Run 2 hysteresis results.

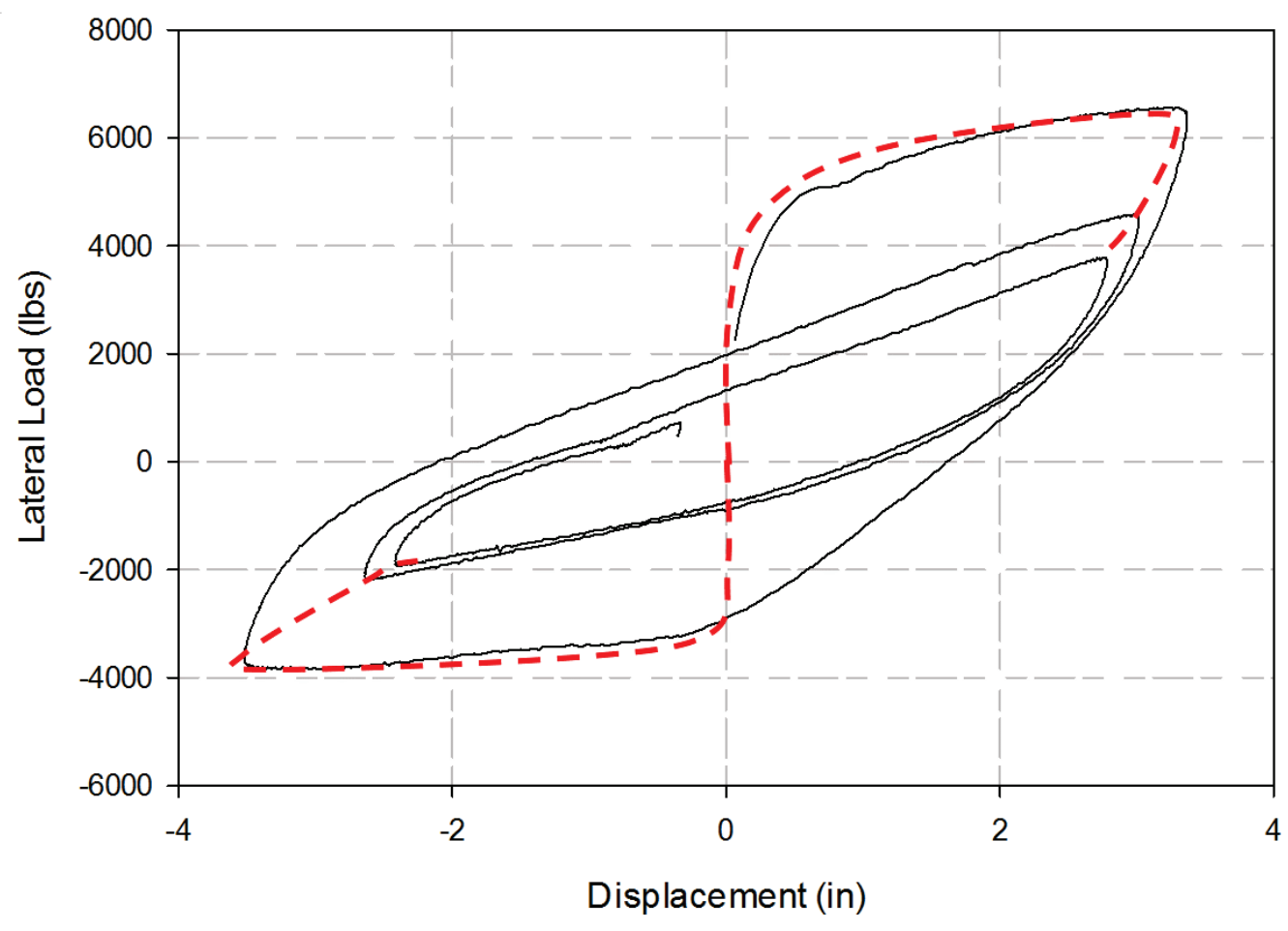

Figure 32. Run 3 hysteresis results.

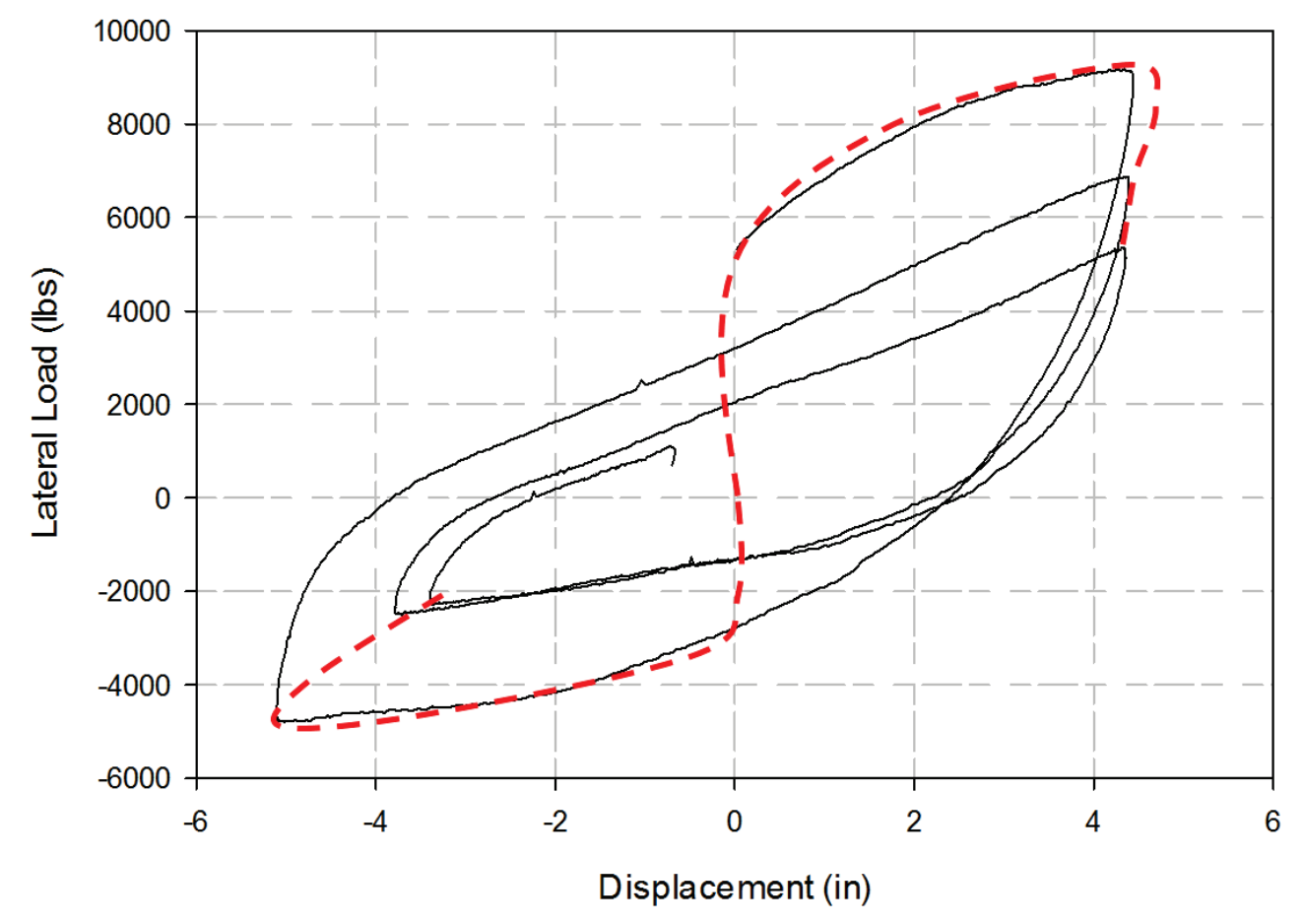


Figure 33. Run 4 hysteresis results.

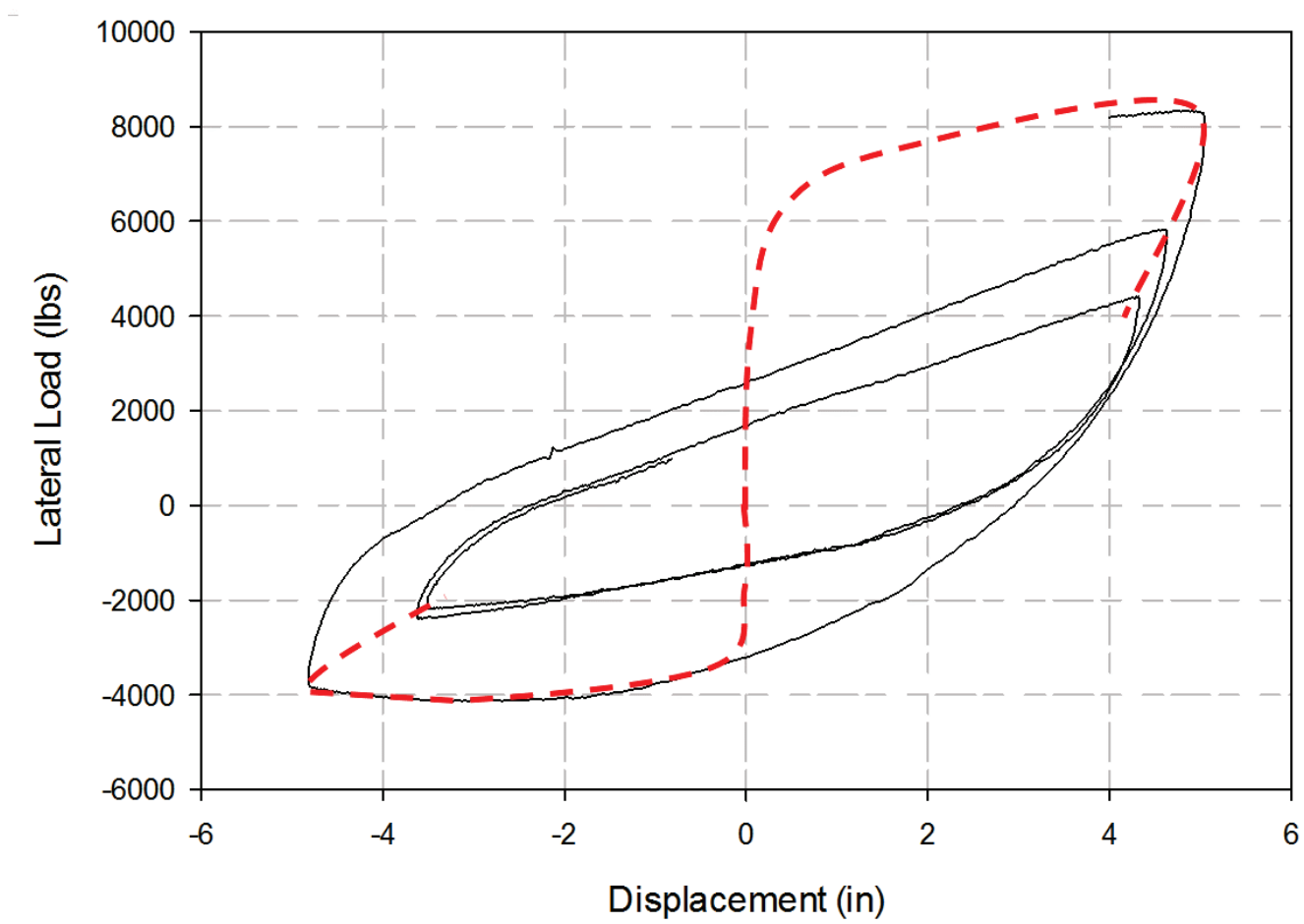

Again, Run 4 (Figure 33) shows the initial displacement of 4 in. Also, we see again that the target displacements of 2, 4, and 6 in. for Runs 1, 2, and 3, respectively, were not achieved (Figure 30 through Figure 32). In each case, degradation of both strength and stiffness are seen. That is, the slope of the elastic line appears to decrease as the test goes on (stiffness degradation) and the hysteresis loops become smaller (strength degradation).

Using a numerical integration scheme, the area of one hysteresis loop (the first loop) was calculated for each run. The results are shown in Table 7.

Table 7. Energy dissipated for first cycle of each run.

\begin{tabular}{|c|c|}
\hline Run & Area of First Loop \\
\hline 1 & 10,673 in-lb \\
\hline 2 & $17,182 \mathrm{in}-\mathrm{lb}$ \\
\hline 3 & $69,236 \mathrm{in}-\mathrm{lb}$ \\
\hline 4 & $34,254 \mathrm{in}-\mathrm{lb}$ \\
\hline
\end{tabular}

The trend indicates that as the displacement and normal load increase, the energy dissipation also increases. However, the energy dissipation for Run 
4 is significantly lower than for Run 3 because neither the displacement amplitude or normal load increased from Run 3 to Run 4.

\subsection{Normal load versus top displacement}

The normal load shedding was plotted against top displacement, as shown in Figure 34 through Figure 37. The first graph in each two-part figure (a) plots the raw data as the three cycles are completed. The normal load decreases as the HESCO unit is cycled through the displacement. The second graph in each pair (b) plots the point of maximum displacement for each oscillation and the associated normal load amount. The apexes are connected with a red dotted line to illustrate the normal load shedding during the course of the cycle. 
Figure 34. Run 1 measured normal load versus top displacement raw data (a) and maximum displacement per oscillation (b).

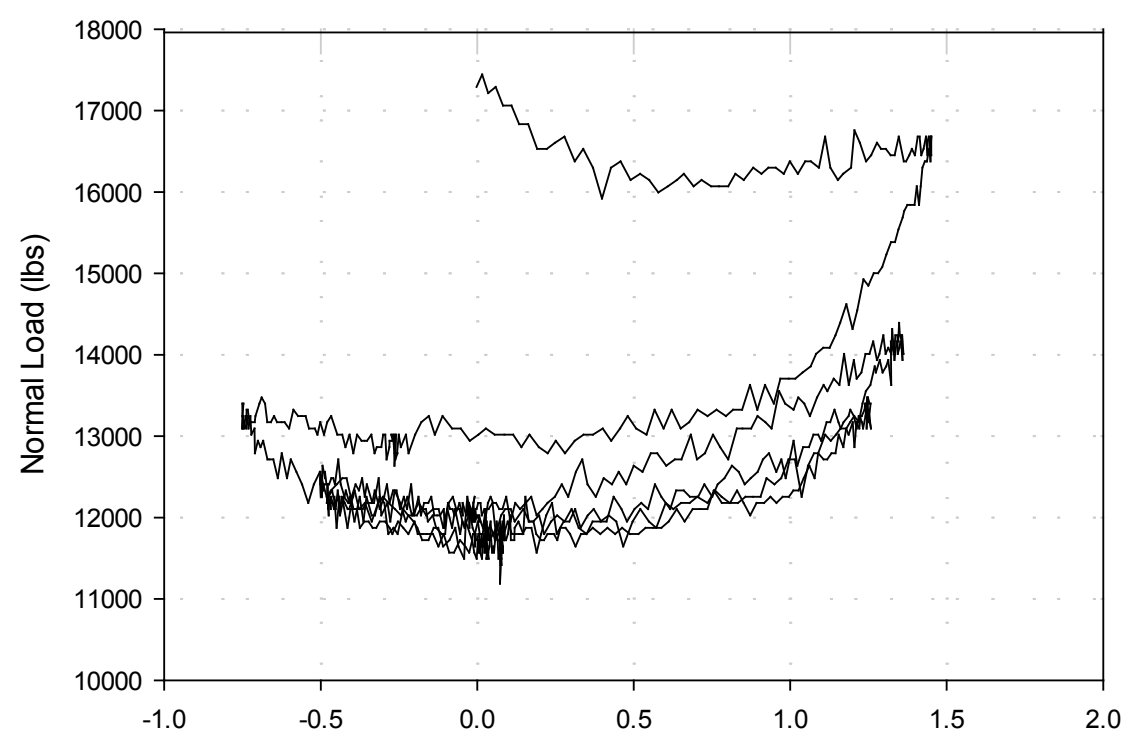

a)

Top Displacement (in.)

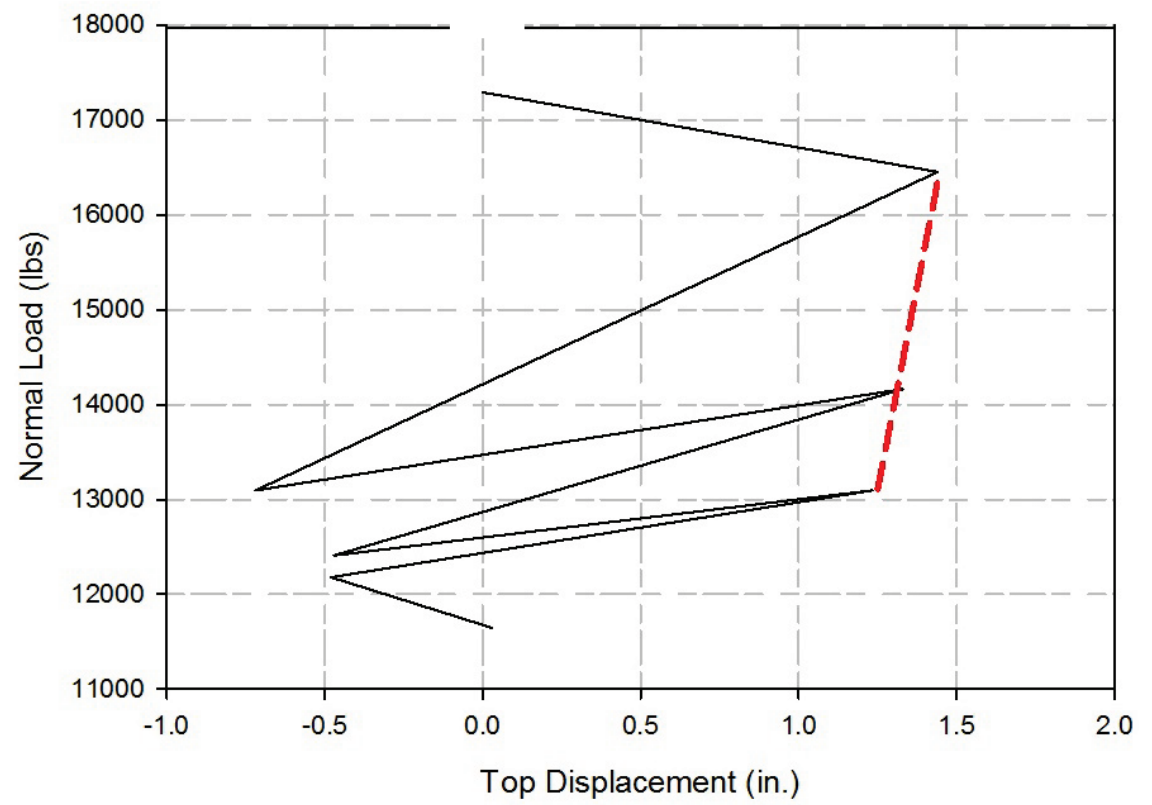

b) 
Figure 35. Run 2 measured normal load versus top displacement raw data (a) and maximum displacement per oscillation (b).

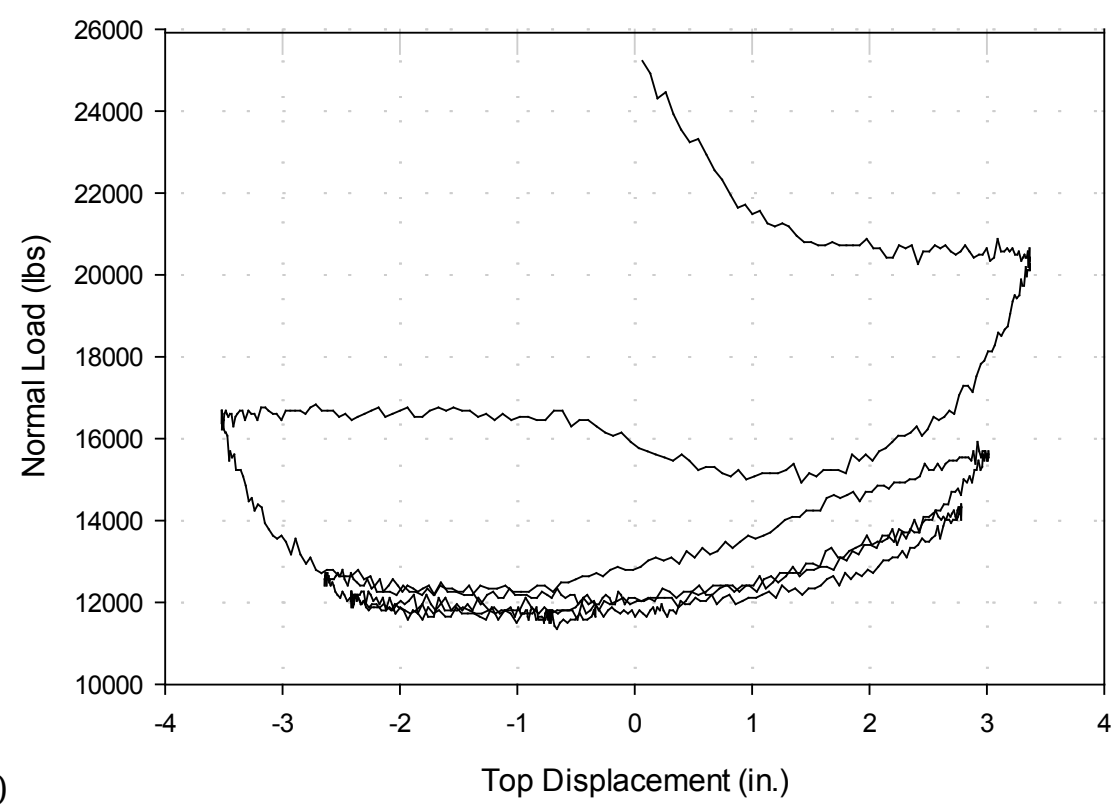

a)

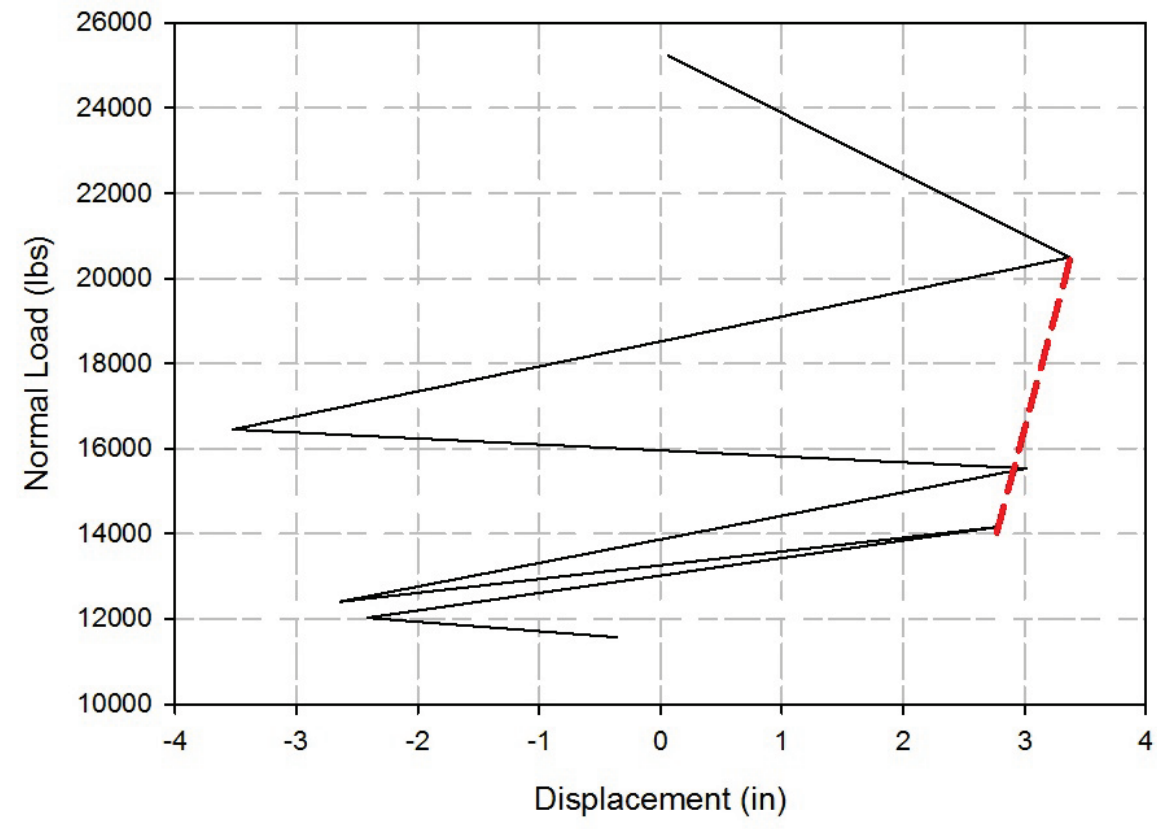

b) 
Figure 36. Run 3 measured normal load versus top displacement raw data (a) and maximum displacement per oscillation (b).

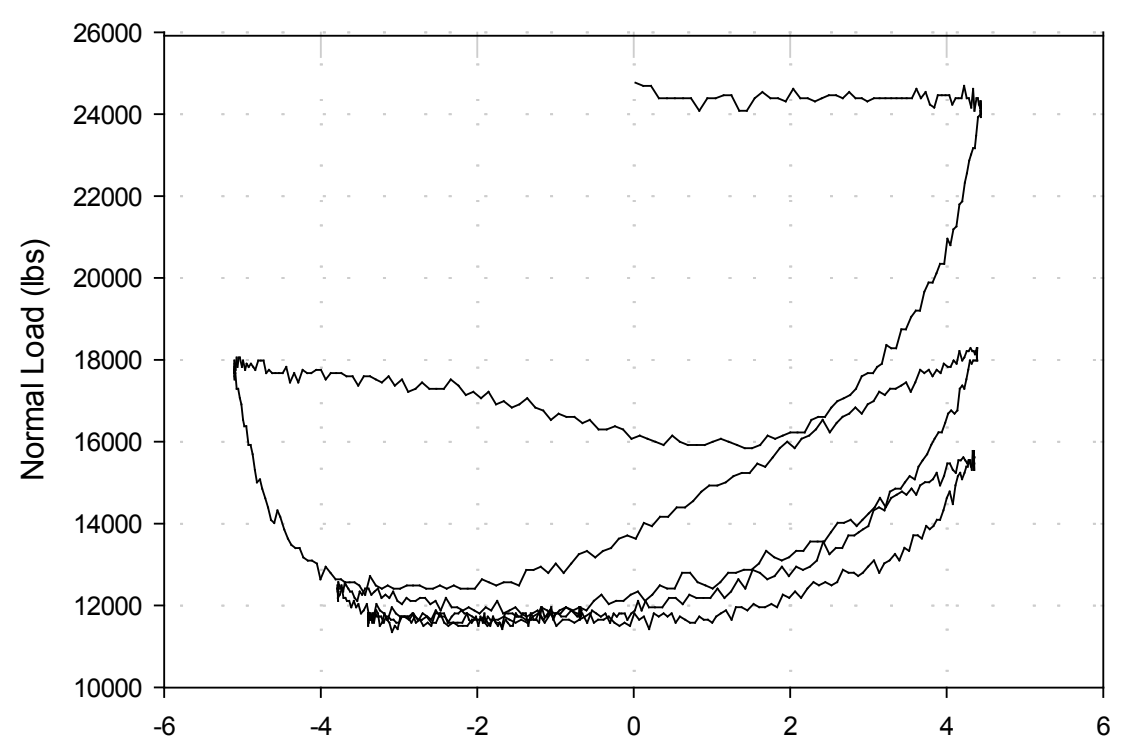

a)

Top Displacement (in.)

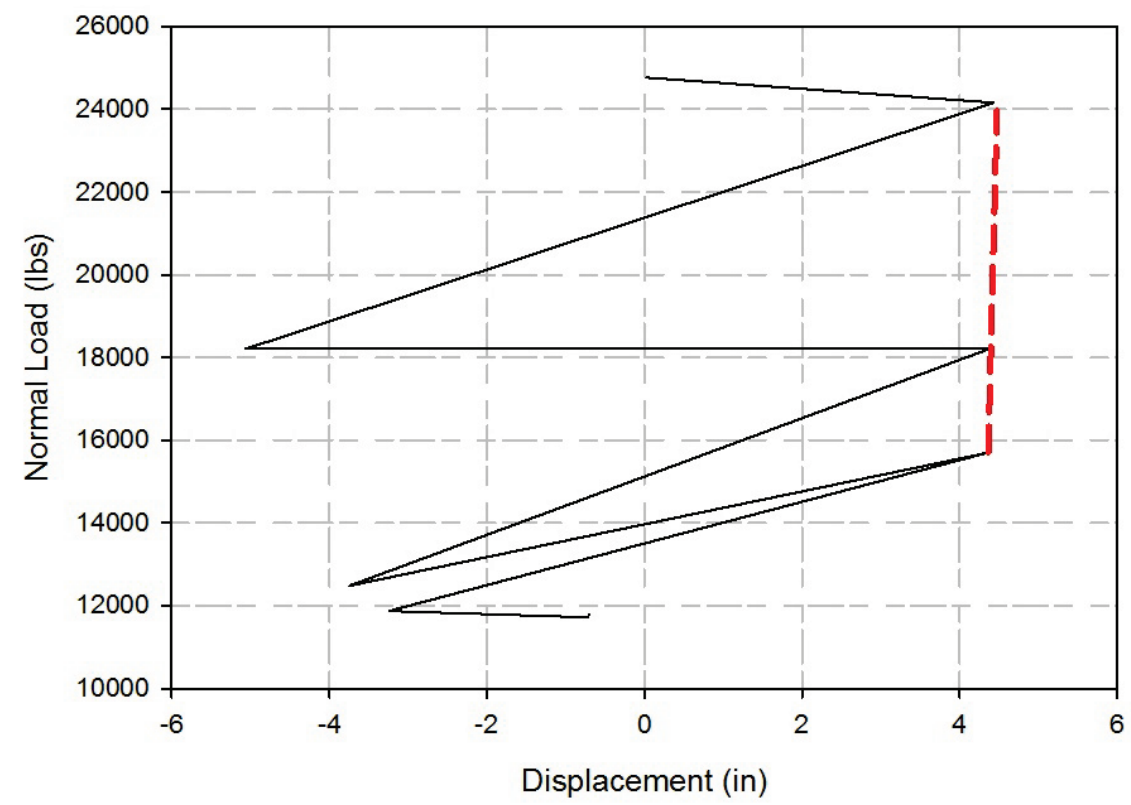

b) 
Figure 37. Run 4 measured normal load versus top displacement raw data (a) and maximum displacement per oscillation (b).

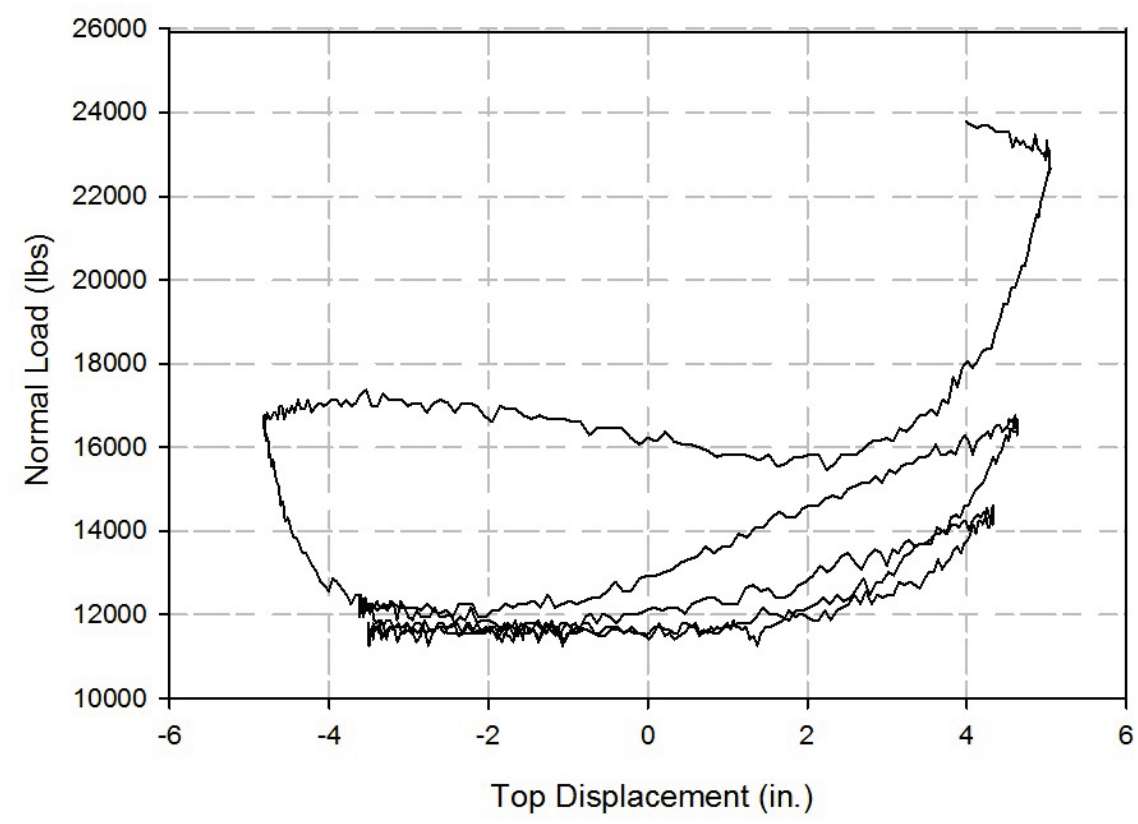

a)

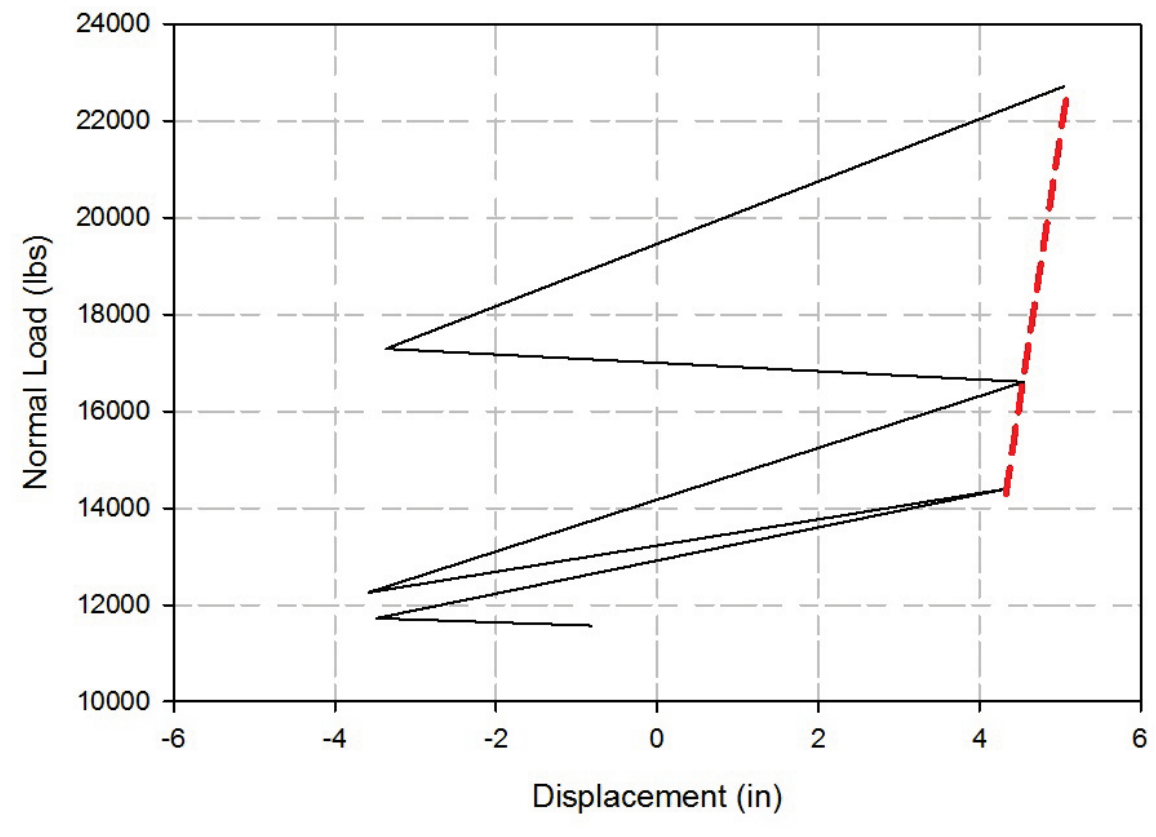

\subsection{Normal load versus lateral load}

The applied normal load was plotted against the lateral load to determine if and how the normal load sheds under cyclic loading. The results are 
shown in Figure 38 through Figure 41. The first graph in each two-part figure (a) plots the raw data as the three cycles are completed. As in the previous section, the normal load decreases as the HESCO unit is cycled through the lateral loads. The second graph (b) plots the point of maximum lateral load for each oscillation and the associated normal load amount. The apexes are connected with a red dotted line to illustrate the normal load shedding during the cycle.

Figure 38. Run 1 normal load versus lateral load raw data (a) and maximum lateral load per oscillation (b).

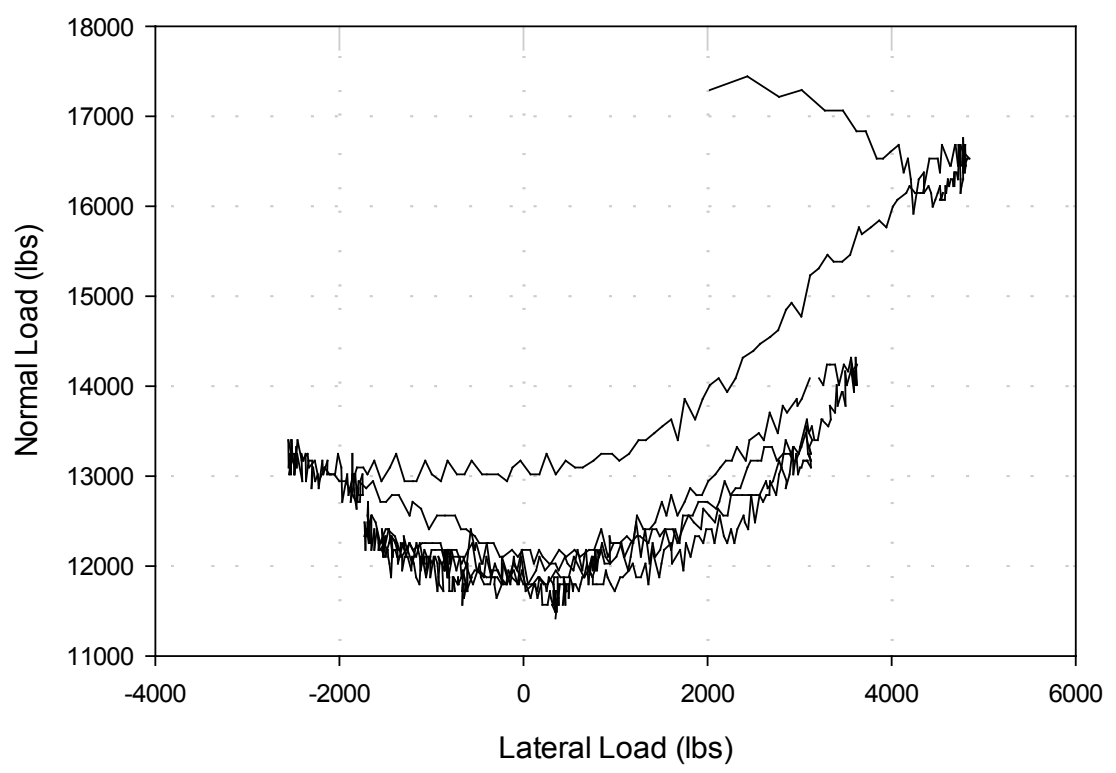

a)

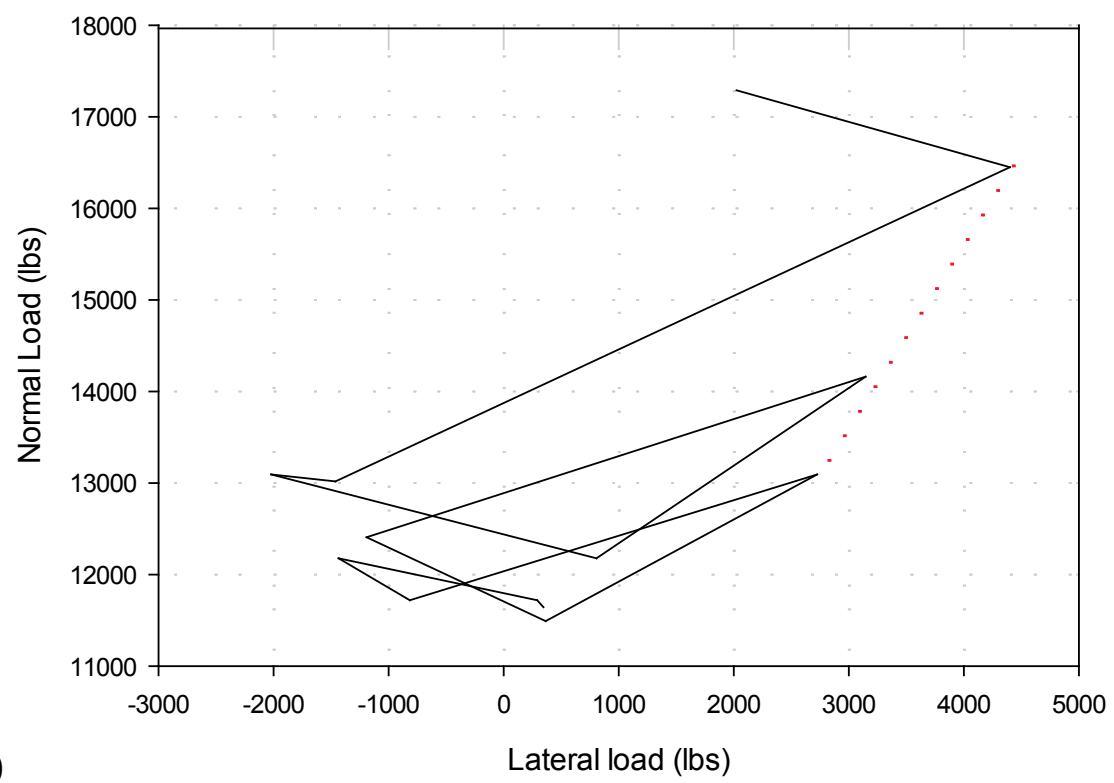

b) 
Figure 39. Run 2 normal load versus lateral load

raw data (a) and maximum lateral load per oscillation (b).
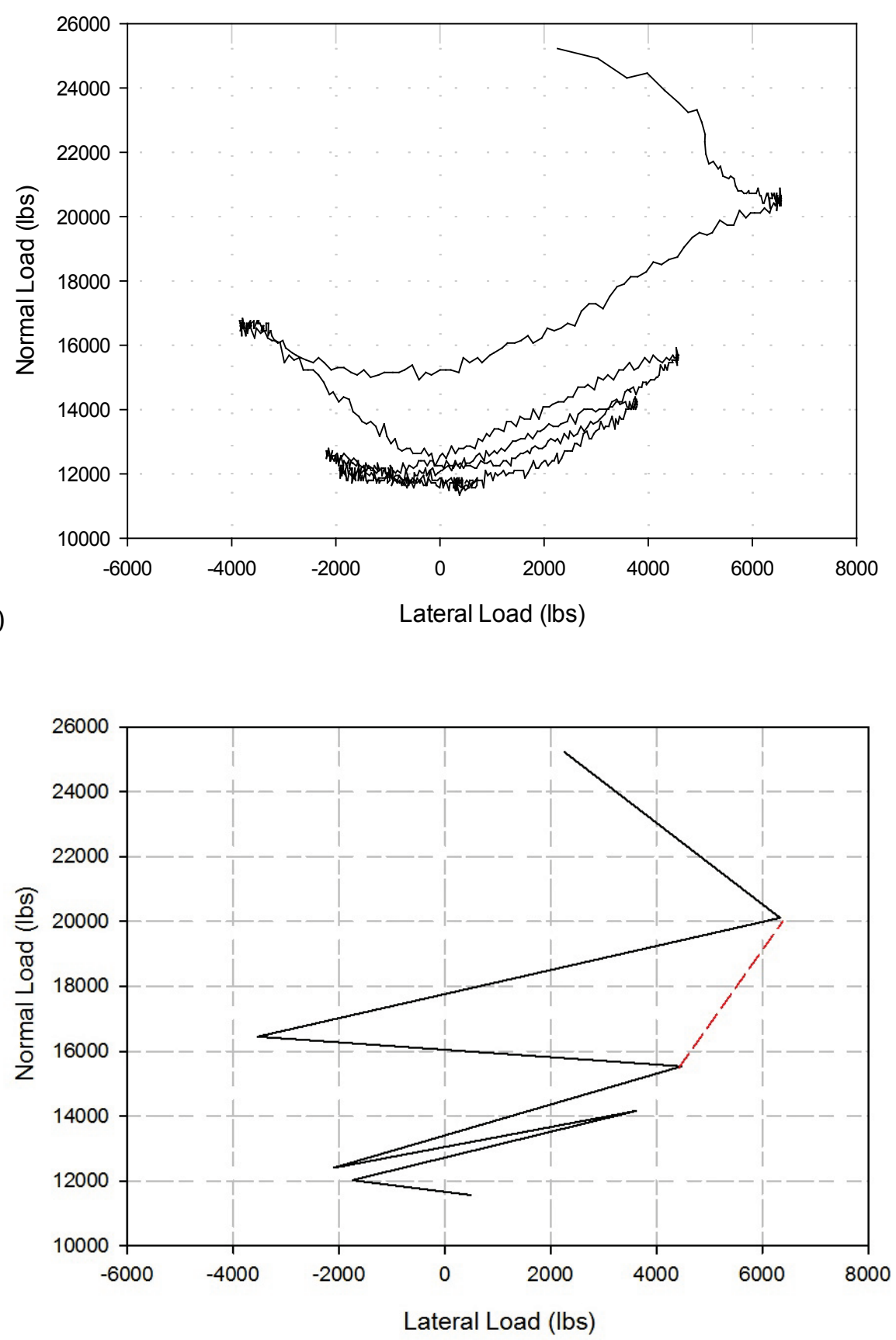

b) 
Figure 40. Run 3 normal load versus lateral load raw data (a) and maximum lateral load per oscillation (b).

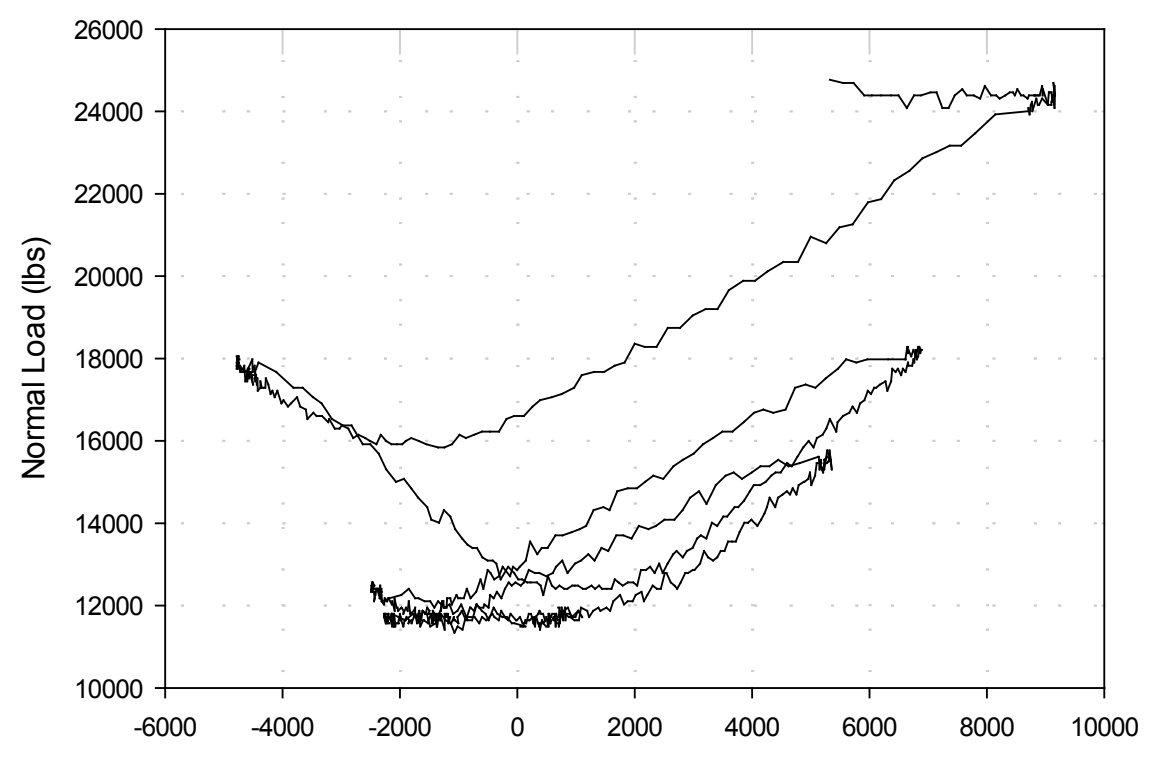

a) Lateral Load (Ibs)

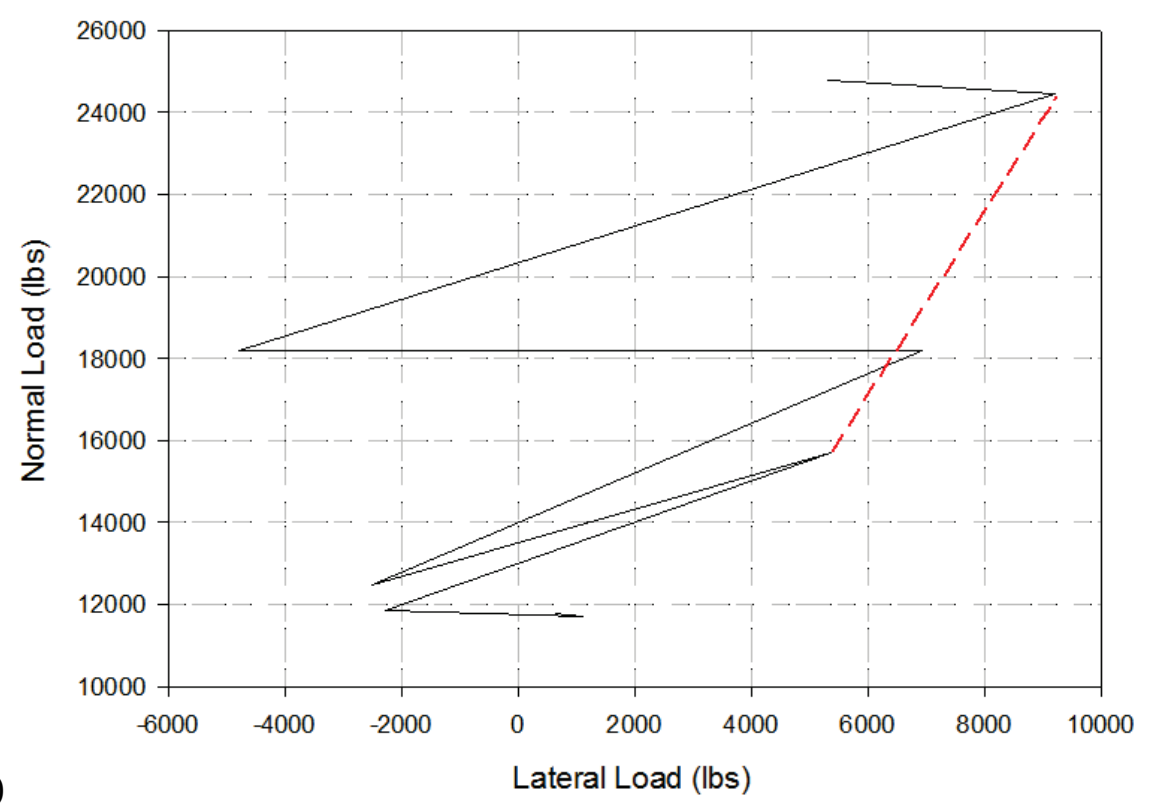


Figure 41. Run 4 normal load versus lateral load raw data (a) and maximum lateral load per oscillation (b).

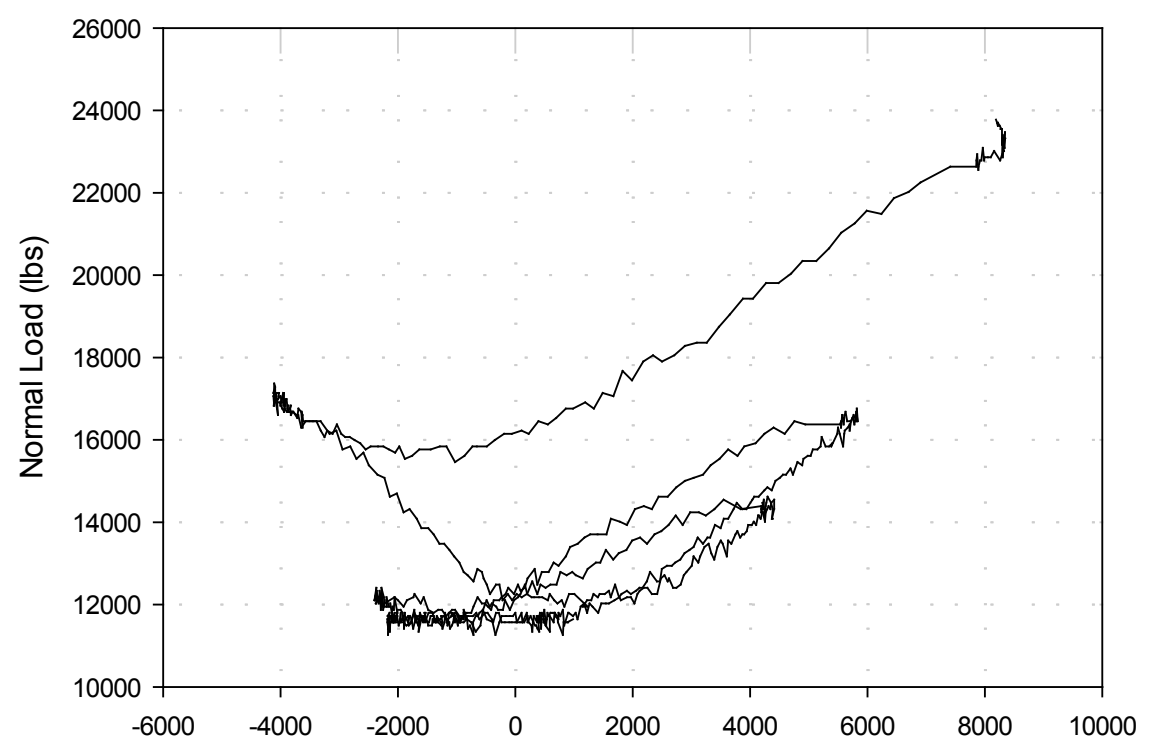

a) Lateral Load (Ibs)

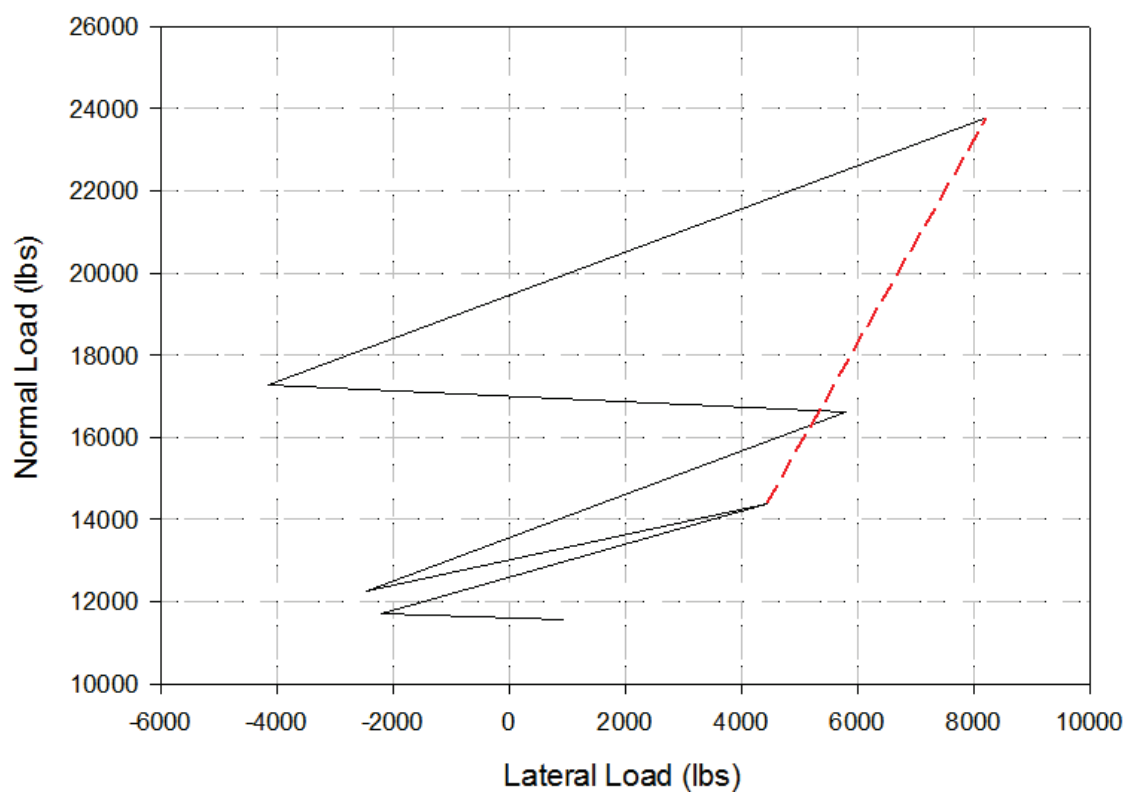

\subsection{Optimum displacements and corresponding loads}

The optimum displacements and corresponding loads for each run are documented in this section, with the results shown in Table 8 through Table 11. 
Table 8. Run 1 optimum displacements and corresponding loads.

\begin{tabular}{|r|r|r|r|}
\hline Time (sec) & Displacement (in.) & Normal Load (lb) & Lateral Load (lb) \\
\hline 0.02 & 0.00 & 17291 & 2025 \\
\hline 15.7 & 1.44 & 16452 & 4401 \\
\hline 29.52 & -0.01 & 13019 & -1463 \\
\hline 46.7 & -0.72 & 13095 & -2021 \\
\hline 57.96 & 0.00 & 12179 & 808 \\
\hline 76.74 & 1.33 & 14163 & 3147 \\
\hline 106.96 & -0.47 & 12408 & -1193 \\
\hline 115.04 & 0.00 & 11493 & 364 \\
\hline 136.76 & 1.23 & 13095 & 2726 \\
\hline 155.2 & 0.00 & 11721 & -818 \\
\hline 165.88 & -0.48 & 12179 & -1436 \\
\hline 174.18 & 0.00 & 11721 & 290 \\
\hline 176.78 & 0.03 & 11645 & 345 \\
\hline
\end{tabular}

Table 9. Run 2 optimum displacements and corresponding loads.

\begin{tabular}{|r|r|r|r|}
\hline \multicolumn{1}{|l|}{ Time (sec) } & Displacement (in.) & Normal Load (lb) & Lateral Load (lb) \\
\hline 0 & 0.07 & 25226 & 2259 \\
\hline 15 & 3.37 & 20114 & 6333 \\
\hline 29.7 & 0.00 & 15994 & -2896 \\
\hline 45.22 & -3.52 & 16452 & -3537 \\
\hline 60.84 & 0.00 & 13019 & 2021 \\
\hline 75.14 & 3.02 & 15536 & 4474 \\
\hline 89.2 & 0.00 & 12103 & -909 \\
\hline 105 & -2.64 & 12408 & -2104 \\
\hline 121.14 & 0.00 & 12179 & 1334 \\
\hline 135.14 & 2.78 & 14163 & 3609 \\
\hline 165.52 & -2.42 & 12027 & -1751 \\
\hline 150.84 & 0.00 & 11798 & -767 \\
\hline 180.9 & -0.36 & 11569 & 487 \\
\hline
\end{tabular}


Table 10. Run 3 optimum displacements and corresponding loads.

\begin{tabular}{|r|r|r|r|}
\hline Time (sec) & Displacement (in.) & Normal Load (lb) & Lateral Load (lb) \\
\hline 3.12 & 0.02 & 5326 & 24768 \\
\hline 14.36 & 4.31 & 9203 & 24463 \\
\hline 30.46 & 0.00 & -2708 & 16070 \\
\hline 44.9 & -5.06 & -4796 & 18207 \\
\hline 63.46 & -0.01 & 3179 & 13629 \\
\hline 75.7 & 4.37 & 6933 & 18207 \\
\hline 91.58 & 0.00 & -1335 & 11721 \\
\hline 105.28 & -3.75 & -2511 & 12484 \\
\hline 123.6 & 0.00 & 2044 & 12179 \\
\hline 135.86 & 4.33 & 5362 & 15689 \\
\hline 153.36 & 0.00 & -1284 & 11874 \\
\hline 164.44 & -3.24 & -2273 & 11874 \\
\hline 182.12 & -0.72 & 1105 & 11721 \\
\hline 183.76 & -0.70 & 624 & 11798 \\
\hline
\end{tabular}

Table 11. Run 4 optimum displacements and corresponding loads.

\begin{tabular}{|r|r|r|r|}
\hline Time (sec) & Displacement (in.) & Normal Load (lb) & Lateral Load (lb) \\
\hline 0 & 4.00 & 23776 & 8192 \\
\hline 21 & 0.00 & 16223 & -3207 \\
\hline 28.12 & -3.37 & 17291 & -4146 \\
\hline 52.4 & 0.00 & 12942 & 2584 \\
\hline 64.4 & 4.55 & 16604 & 5807 \\
\hline 82.88 & 0.00 & 11721 & -1280 \\
\hline 95.06 & -3.59 & 12256 & -2443 \\
\hline 113.04 & 0.00 & 12179 & 1691 \\
\hline 125.34 & 4.31 & 14392 & 4456 \\
\hline 143.64 & 0.00 & 11721 & -1211 \\
\hline 155.52 & -3.49 & 11721 & -2191 \\
\hline 171.62 & -0.82 & 11569 & 968 \\
\hline
\end{tabular}

\subsection{Failure modes}

After the four test runs, the HESCO specimen was inspected for damage that may have occurred to the frame and fabric members. Six photographs showing the end state of the specimen are included in Figure 42. In particular, inelastic buckling of the wire mesh was observed near the base of the 
unit, as well as the spiral hinge at the corner of the unit. This inelastic buckling, called "elephant foot," led to permanent visible deformation at the base of the HESCO unit and was most pronounced on the front and back faces of unit (in the direction of the displacement).

Figure 42. Photographs of failure modes seen in HESCO unit.

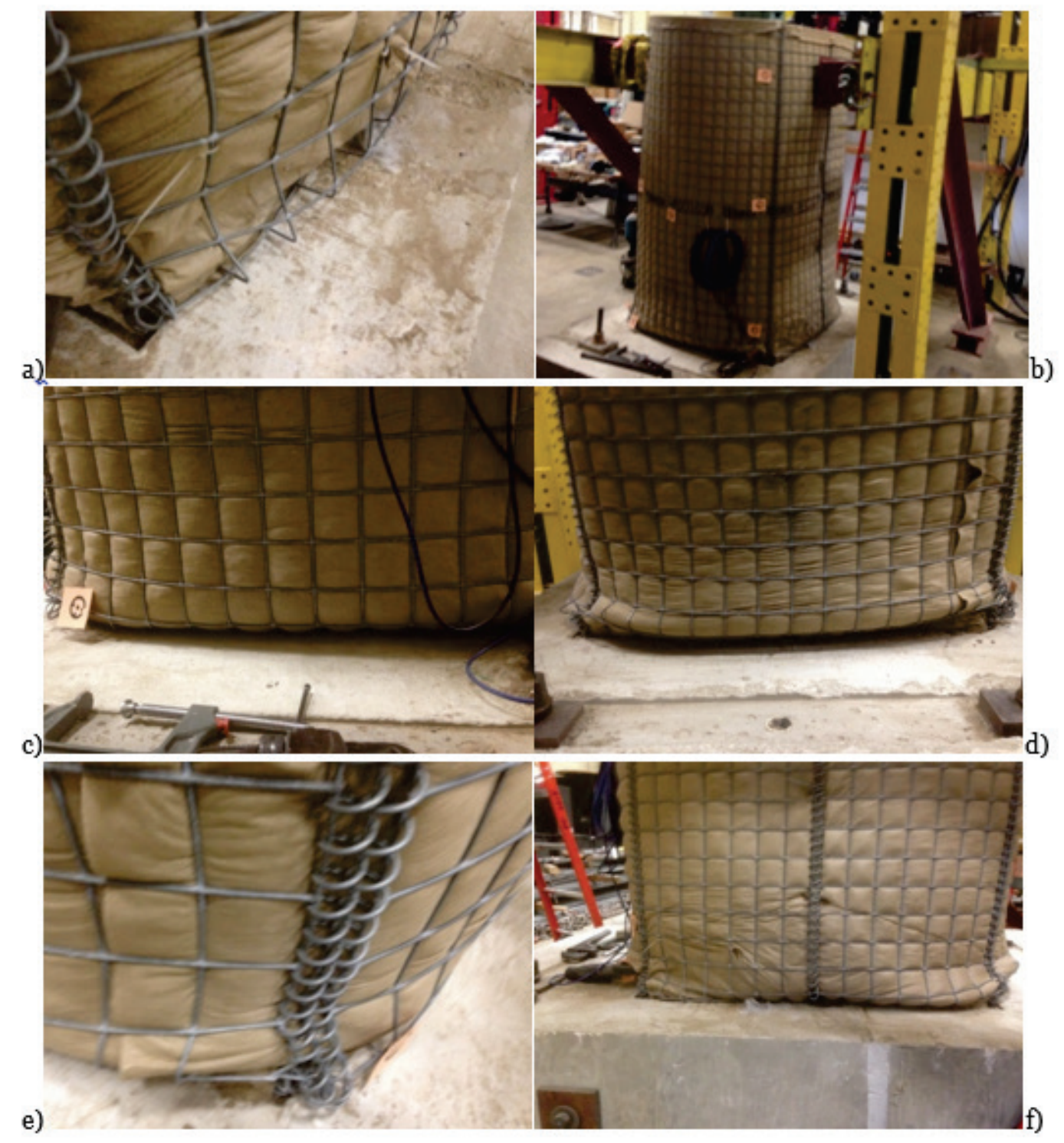

The primary mechanism to resist overturning from the lateral load is axial compression in the sand fill and welded mesh, which leads to buckling. This tendency to buckle is compounded by the lateral earth pressure exerted by the sand fill. The compressive load on the mesh in resisting overturning from the applied lateral force would be expected to be nearly constant. However, the lateral earth pressure in the basket is largest at the 
base of the specimen, so buckling is most likely to occur at the base. That assumption was verified in the test results.

The elephant-foot buckling condition, which is visible in most of the Figure 42 images, was the exclusive failure mode seen in this testing program. No part of the fabric failed during the test, and no sand was spilled, even at the base of the unit where the fabric would be expected to experience the highest stresses. Furthermore, the unit was not observed to slide during the test.

\subsection{Summary of results}

The main results of the tests are shown in the figures below, which provide the load shedding curves generated during each run. Figure 43a shows normal load versus displacement. The steepest curve is for Run 3, which also had the highest normal load. Figure $43 \mathrm{~b}$ shows the normal load versus lateral load. The curve for Run 1 has the lowest normal load.

Figure 43. Comparison of load shedding curves for each run (a-c).

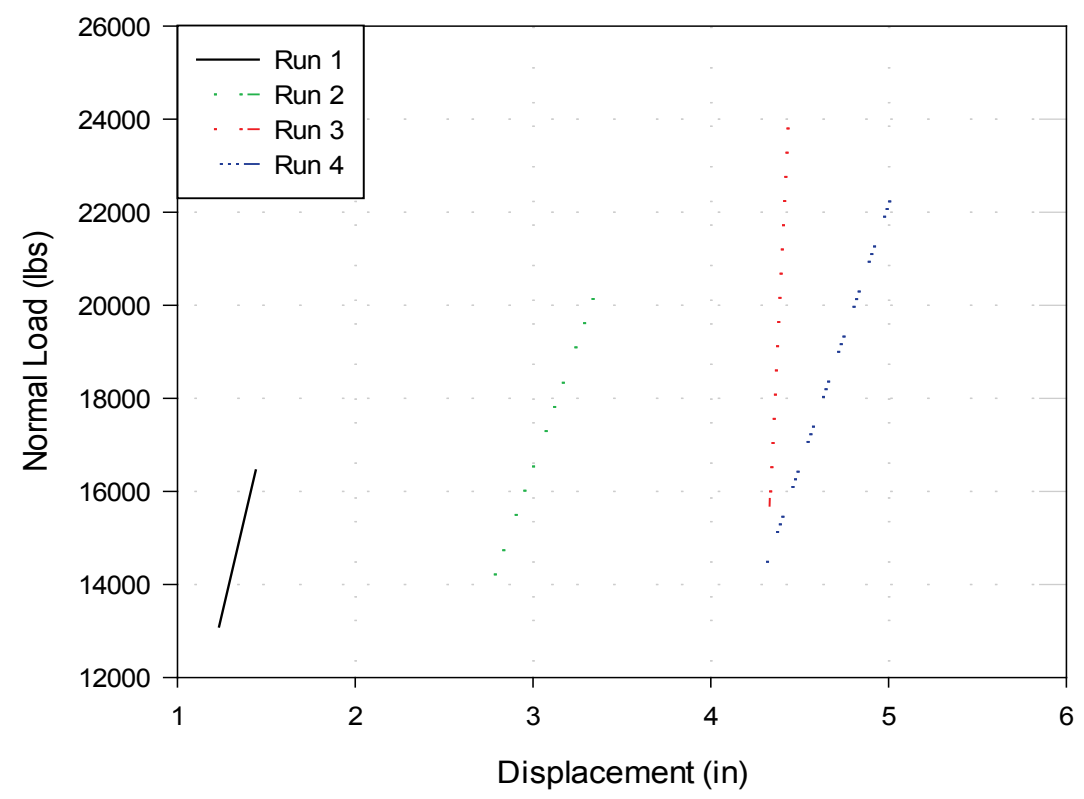


Figure 44 (continued and concluded).

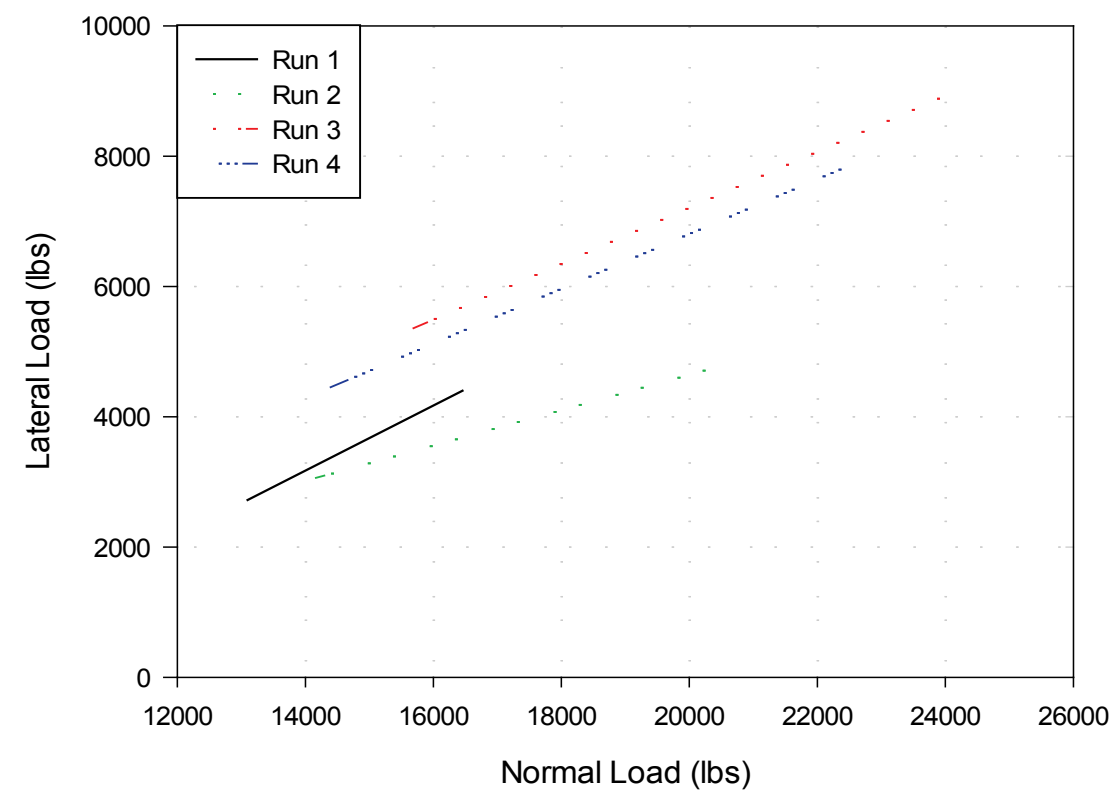

b.

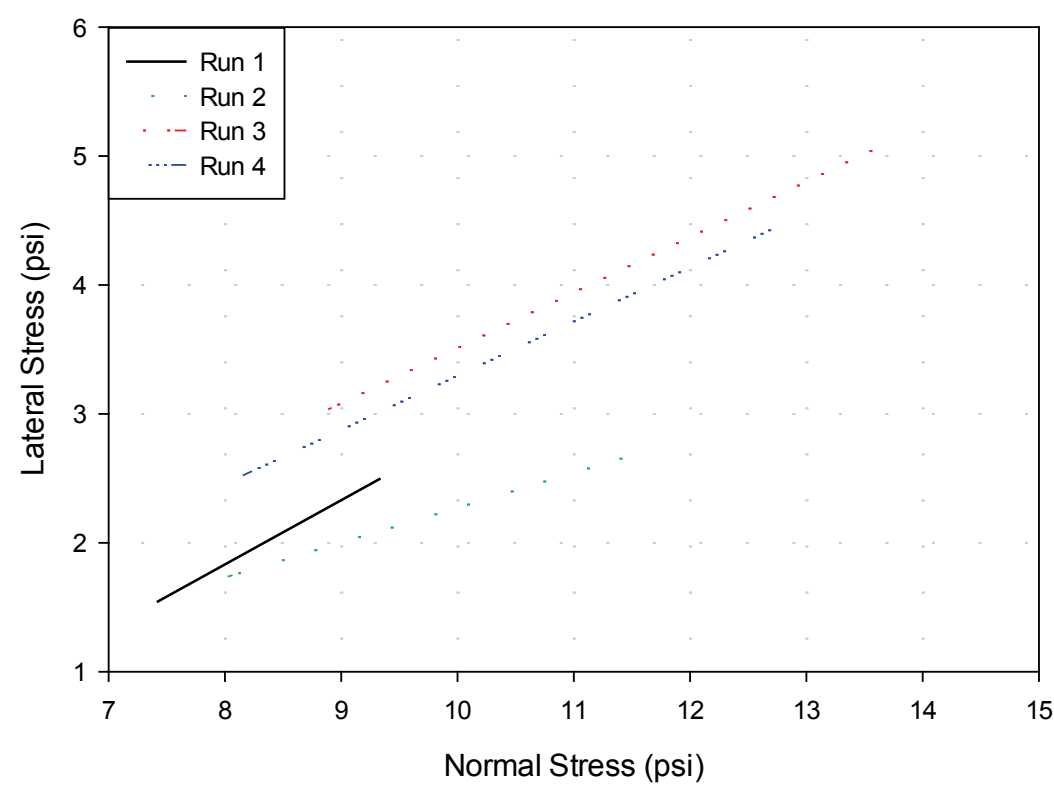

Assuming the lateral load is dependent on the applied normal load, the axes in Figure 43 were oriented such that the lateral load was placed on the y-axis. Subsequently, equations of the lines seen in Figure 43 are calculated readily. Note that the units in Figure 43c are force. The tests were conducted on a $3.5 \times 3.5 \mathrm{ft}$ (i.e., $42 \times 42$ in.) cross-section, and units were converted to stress using this cross section and the assumption that lateral 
load is resisted primarily by the shear action in the fill. The equations are as follows:

$$
\begin{aligned}
& \text { Run 1: } f_{L}=0.53 f_{n}-2.44 \\
& \text { Run 2: } f_{L}=0.27 f_{n}-0.44 \\
& \text { Run 3: } f_{L}=0.43 f_{n}-0.79 \\
& \text { Run 4: } f_{L}=0.42 f_{n}-0.91
\end{aligned}
$$

where:

$$
\begin{aligned}
& f_{L}=\text { allowable lateral stress }(p s i) \\
& f_{n}=\text { applied normal stress }(p s i)
\end{aligned}
$$




\section{Conclusions and Recommendations}

\subsection{Conclusions}

This study validated the suitability of HESCO bastion units for use as loadbearing structural members in expedient housing designs for soldiers stationed at FOBs in Army areas of operation. This assessment is supported by the following conclusions:

1. The test results confirmed the hypothesis that the lateral load would increase as the normal load was increased.

2. Use of HESCO bastion was validated provided that it meets the design requirements for the specific residential structural application. The tests showed a significant normal load-resistance capacity, and a combined load-resistance capacity when lateral load is applied. (Note the type of sand used in this testing program was average in shear.)

3. The HESCO bastion failure mode, elephant-foot buckling, was such that the fabric held up well, as did the wire mesh except under compression. This result was expected, however, and would not negatively affect the stability of the structure assumed in these tests.

4. Although an unconfined boundary condition was tested in this study, configuring a structure using the other conditions described in section 2.3 could increase the capacity of the system and decrease failure due to bowing. Also, the use of the other boundary conditions restricts the unit from moving at the base, thereby decreasing its potential for torsional failure.

5. Run 1 had the smallest displacement while Run 3 had the largest. This result was due to the increased compaction of the fill as the normal load increased. The level of displacement affected the normal load versus lateral load in that, as the fill compacted the lateral load increased to contain the horizontal expansion of the fill.

6. The relationship between normal load and lateral load is linear, as illustrated by the equations given in section 4.10.

\subsection{Recommendations}

The proposed design for temporary housing using HESCO bastions, filled with local indigenous soil, could be included as a standard design in the 
Army Facilities Components System (AFCS) database. Also, a design procedure incorporating HESCO technology could be incorporated into U.S. standards and specifications such as the Unified Facility Criteria (UFC).

Applicability of the system could be improved or extended with follow-on testing or investigation addressing the following issues:

1. Further testing for the best design-value combination of normal and lateral load in terms of displacement effects

2. Use of additional mesh to better resist bowing of the basket, including the amount and placement of the mesh with respect to boundary conditions applied in structural designs

3. Testing of smaller HESCO unit cross sections to determine whether units smaller than the tested $3.5 \times 3.5 \mathrm{ft}$ dimensions would be applicable and as effective as the tested unit size.

Taking the average of the slopes and intercepts of the four design relationships stated in section 4.10, the recommended design relationship between lateral and normal stress is calculated as

$$
f_{L}=0.42 f_{n}-0.91
$$

where

$f_{L}=$ allowable lateral stress (psi)

$f_{n}=$ applied normal stress (psi)

This relationship is recommended with the assumption that shear stress in the sand fill is the primary lateral-force-resisting mechanism. However, the failure mode observed at the base of the unit (i.e., the elephant-foot buckling) suggests that there was, at least, some degree of compression in the welded-wire-mesh caused by an overturning moment. A wire with the properties listed in section 2.1 will have a significant yield stress of nearly $2 \mathrm{ksi}$. However, for the dimensions of the tested wire, this figure translates to a compressive force of approximately $40 \mathrm{lb}$. As noted in section 4.9, the tendency for elephant-foot buckling is exacerbated by the lateral earth pressure caused by the self-weight of the sand fill, and as buckling did occur, the yield stress and, therefore, yield load in the wire is probably significantly lower than the pure compressive yield stress. Follow-on work 
would be needed to investigate the relationship between shear stress, overturning moment, lateral earth pressure, and wire buckling/yielding. However, in this study, the effects of overturning moment were deemed insignificant. 


\section{References}

[1] U.S. Department of Defense. 2014. Detail Specification: Expeditionary Barrier System (EBS). Washington, DC: U.S. Department of Defense.

[2] ASTM International. 2012. Standard Specification for GALFAN (Zinc-5\% Aluminum-Mischmetal) Alloy in Ingot Form for Hot-Dip Coatings. ASTM B75012. West Conshohocken, PA: ASTM International.

[3] ASTM International. 2014. Standard Specification for Zinc-5\% AluminumMischmetal Alloy-Coated Carbon Steel Wire. ASTM A856/A856M-03. West Conshohocken, PA: ASTM International.

[4] Redbuilt Engineered Wood Products. 2015. Red I-Joists Product Brochure. Boise, ID: Redbuilt.

[5] ASTM International. 2011. Standard Test Methods for Cyclic (Reversed) Load Test for Shear Resistance of Vertical Elements of the Lateral Force Resisting Systems for Buildings. ASTM E2125-11. West Conshohocken, PA: ASTM International. 


\section{Appendix A: HESCO Building Design}

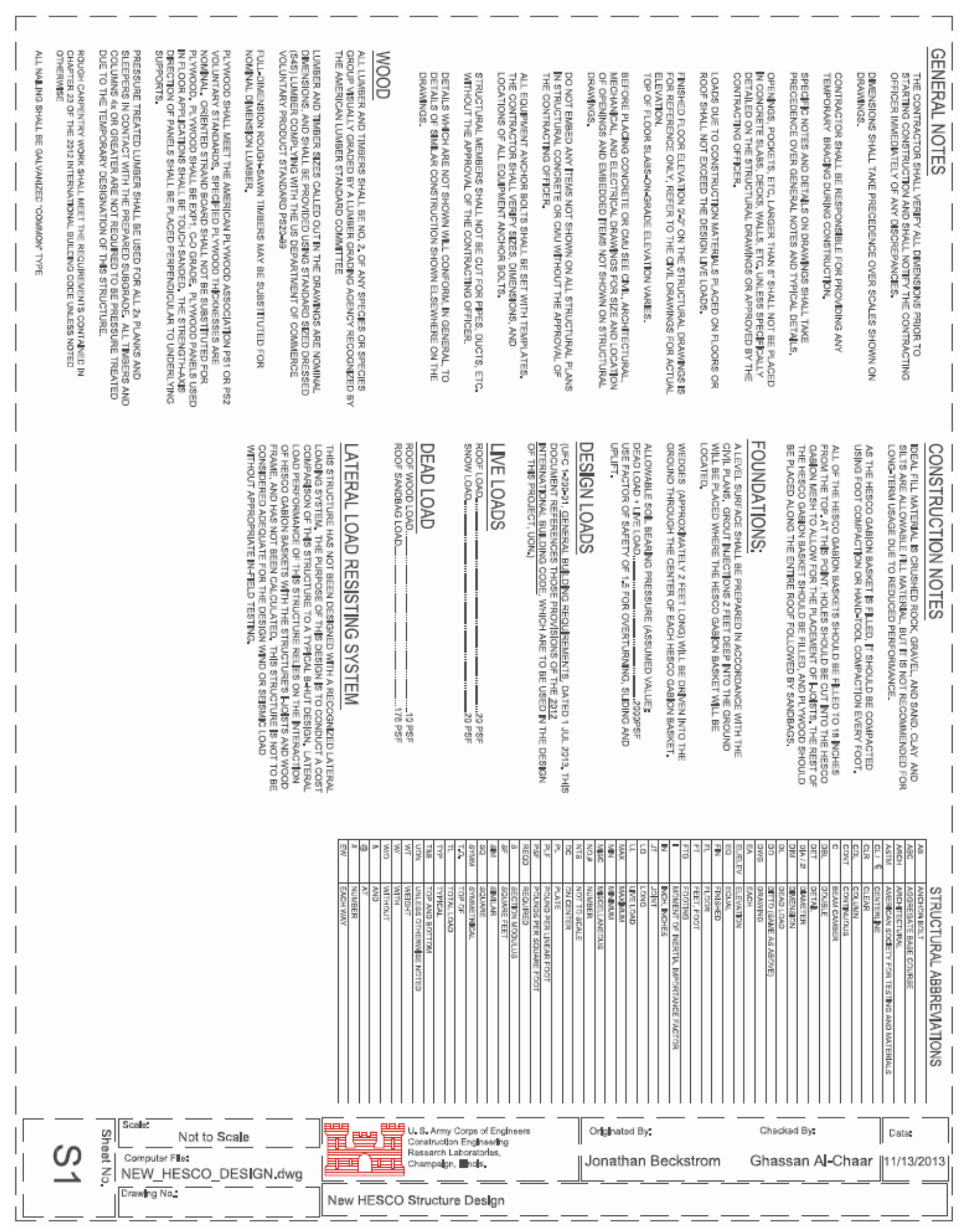




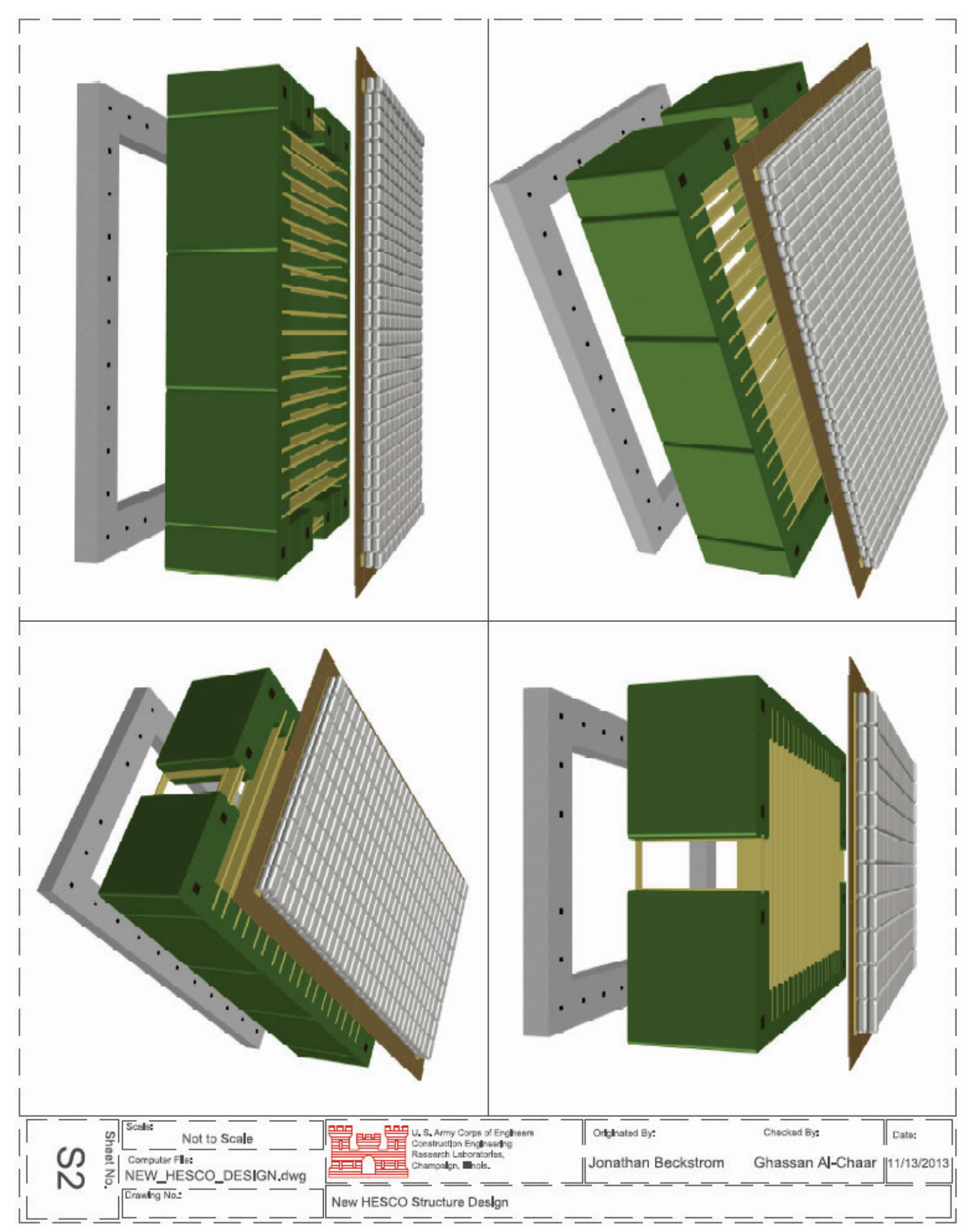




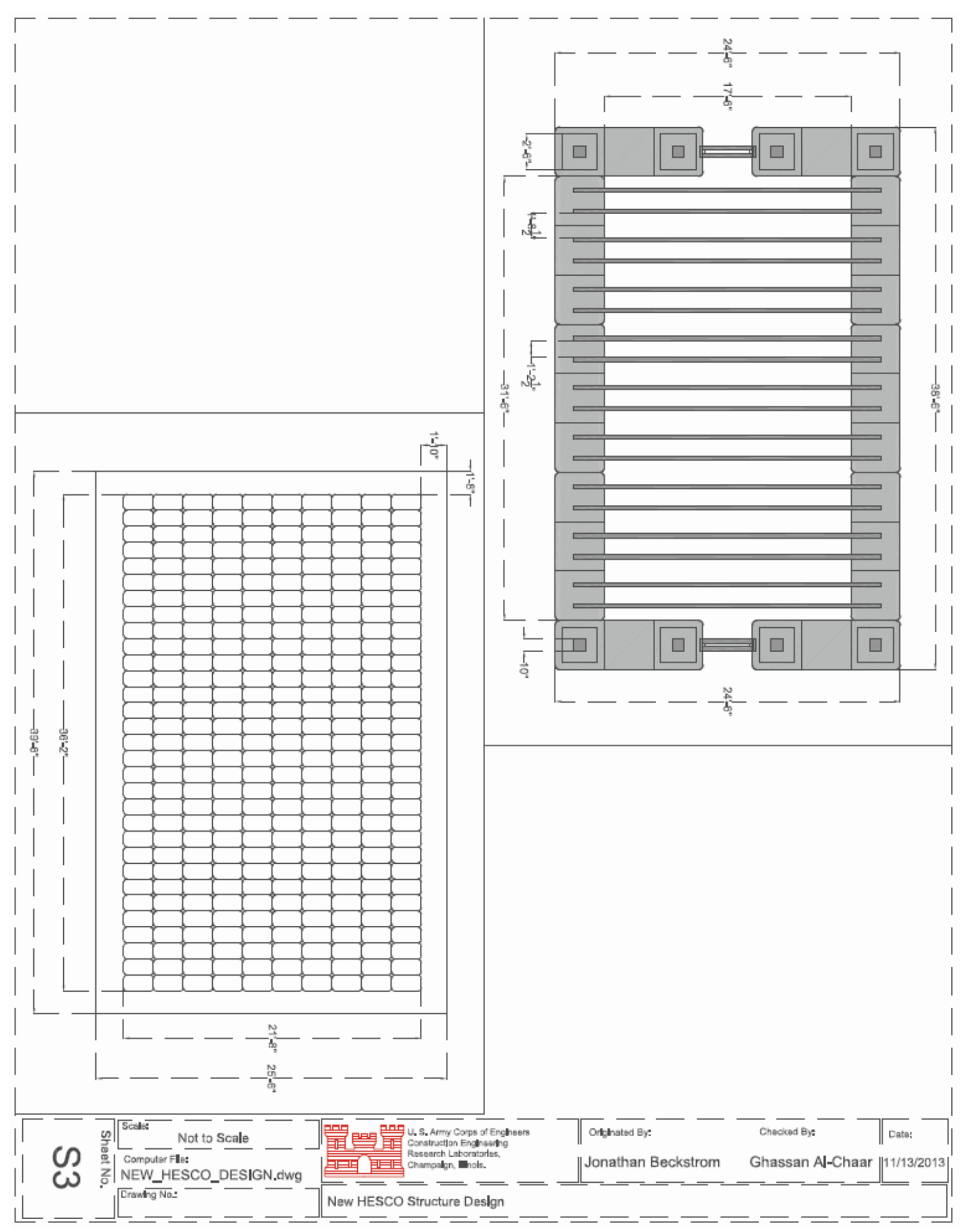




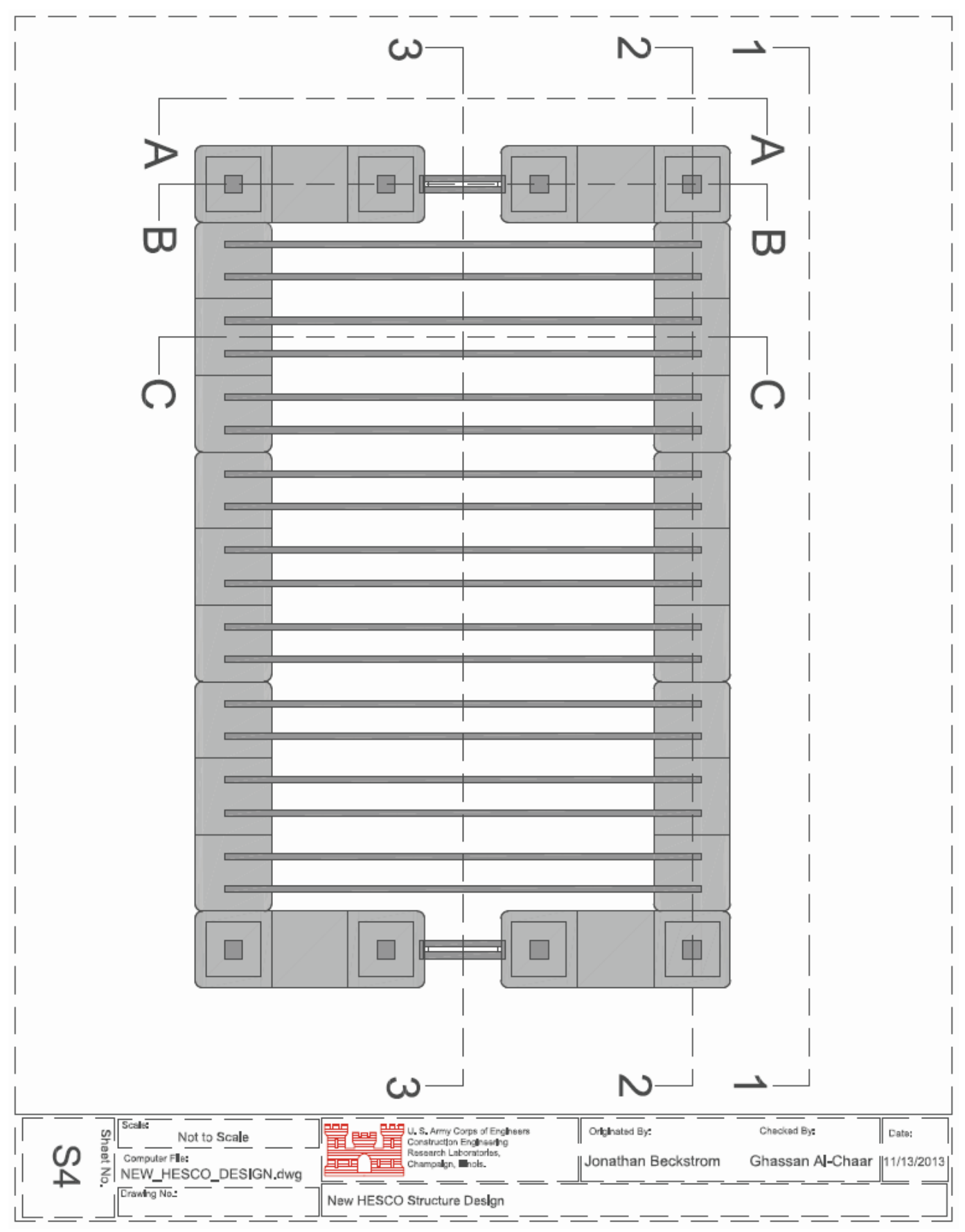




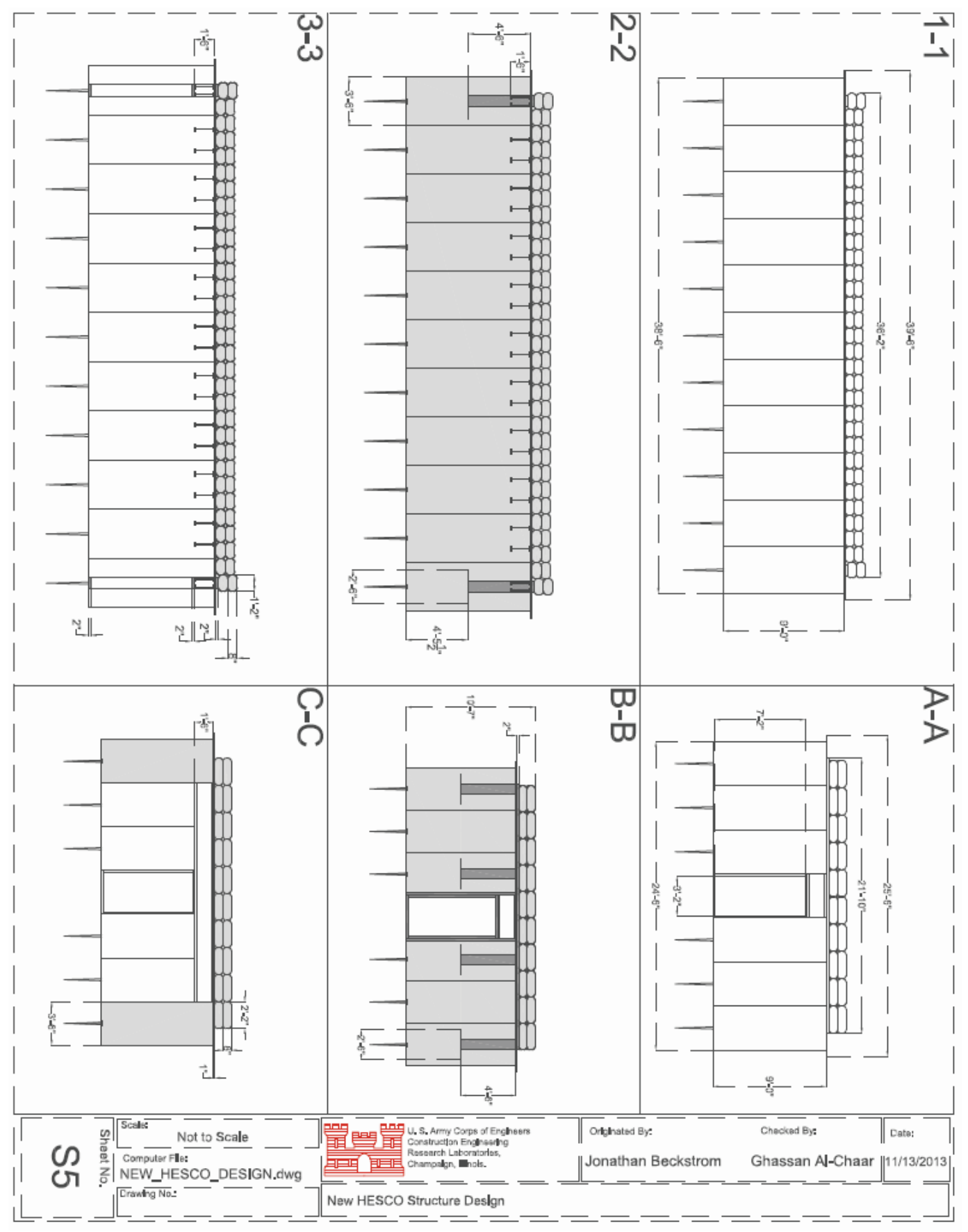




\title{
Appendix B: MIL-DTL-32488
}

\author{
INCH-POUND \\ MIL-DTL-32488 \\ 15 January 2014
}

\section{DETAIL SPECIFICATION}

EXPEDITIONARY BARRIER SYSTEM (EBS)

This specification is approved for use by all Departments and Agencies of the Department of Defense.

\section{SCOPE}

1.1 Scope. This specification covers the procurement requirements for the Expeditionary Barrier System (EBS) which is a cellular welded wire mesh gabion system that is lined with geotextile fabric to contain fill material. The EBS is intended for use as a rapidly deployable force protection barrier that is collapsible for transport and then filled on-site with soil or other material to obtain structural integrity and protective performance. It is designed for use in expedient force protection barrier wall construction for expeditionary and austere environments.

1.2 Classification. The EBS has the following types and classes as specified in the contract or purchase order (see 6.2).

1.2.1 Types. The EBS types are designated from 1 through 12 (see Table III).

1.2.2 Classes. The EBS classes are designated as follows:

$\begin{array}{cl}\text { Class } & \text { Color } \\ \text { B } & \text { Beige/Sand } \\ \text { G } & \text { Green }\end{array}$

\section{APPLICABLE DOCUMENTS}

2.1 General. The documents listed in this section are specified in sections 3,4 , or 5 of this specification. This section does not include documents cited in other sections of this specification or recommended for additional information or as examples. While every effort has been made to ensure the completeness of this list, document users are cautioned that they must meet all specified requirements of documents cited in sections 3,4 , or 5 of this specification, whether or not they are listed.

\subsection{Government documents.}

2.2.1 Specifications, standards, and handbooks. The following specifications and standards form a part of this document to the extent specified herein. Unless otherwise specified, the issues of these documents are those cited in the solicitation or contract.

Comments, suggestions, or questions on this document should be addressed to Defense Supply Center Philadelphia (DSCP), ATTN: DSCP-NASA, 700 Robbins Avenue, Philadelphia, PA 19111-5096 or e-mail to dscpg\&ispecomments@dla.mil. Since contact information can change, you may want to verify the currency of this address information using the ASSIST Online database at https /lassist.dla.mil . 
MIL-DTL-32488

FEDERAL STANDARDS

MIL-STD-810

Environmental Engineering Considerations and Laboratory Tests

(Copies of these documents are available online at https://assist.dla.mil or from the Standardization Document Order Desk, 700 Robbins Avenue, Building 4D, Philadelphia, PA 19111-5094.)

2.3 Non-Government publications. The following documents form a part of this document to the extent specified herein. Unless otherwise specified, the issues of these documents are those cited in the solicitation or contract.

\section{AMERICAN SOCIETY FOR TESTING AND MATERIALS (ASTM)}

\begin{tabular}{|c|c|}
\hline ASTM A90/A90M & $\begin{array}{l}\text { Standard Test Method for Weight [Mass] of Coating on } \\
\text { Iron and Steel Articles with Zinc or Zinc-Alloy Coatings }\end{array}$ \\
\hline ASTM A185/A185M & $\begin{array}{l}\text { Standard Specification for Steel Welded Wire } \\
\text { Reinforcement, Plain, for Concrete }\end{array}$ \\
\hline ASTM A856/A856M & $\begin{array}{l}\text { Standard Specification for Zinc-5 \% Aluminum- } \\
\text { Mischmetal Alloy-Coated Carbon Steel Wire }\end{array}$ \\
\hline ASTM B750 & $\begin{array}{l}\text { Standard Specification for GALFAN (Zinc- } 5 \% \\
\text { Aluminum-Mischmetal) Alloy in Ingot Form for Hot- } \\
\text { Dip Coatings }\end{array}$ \\
\hline ASTM D4355 & $\begin{array}{l}\text { Standard Test Method for Deterioration of } \\
\text { Geotextiles by Exposure to Light, Moisture and Heat } \\
\text { in a Xenon Arc Type Apparatus }\end{array}$ \\
\hline ASTM D4491 & $\begin{array}{l}\text { Standard Test Methods for Water Permeability of } \\
\text { Geotextiles by Permittivity }\end{array}$ \\
\hline ASTM D4533 & $\begin{array}{l}\text { Standard Test Method for Trapezoid Tearing } \\
\text { Strength of Geotextiles }\end{array}$ \\
\hline ASTM D4595 & $\begin{array}{l}\text { Standard Test Method for Tensile Properties of } \\
\text { Geotextiles by the Wide-Width Strip Method }\end{array}$ \\
\hline ASTM D4632/D4632M & $\begin{array}{l}\text { Standard Test Method for Grab Breaking Load and } \\
\text { Elongation of Geotextiles }\end{array}$ \\
\hline ASTM D4751 & $\begin{array}{l}\text { Standard Test Method for Determining Apparent } \\
\text { Opening Size of a Geotextile }\end{array}$ \\
\hline ASTM D5035 & $\begin{array}{l}\text { Standard Test Method for Breaking Force and } \\
\text { Elongation of Textile Fabrics (Strip Method) }\end{array}$ \\
\hline ASTM D5199 & $\begin{array}{l}\text { Standard Test Method for Measuring the Nominal } \\
\text { Thickness of Geosynthetics }\end{array}$ \\
\hline ASTM D5261 & $\begin{array}{l}\text { Standard Test Method for Measuring Mass per Unit } \\
\text { Area of Geotextiles }\end{array}$ \\
\hline ASTM D6241 & $\begin{array}{l}\text { Standard Test Method for the Static Puncture } \\
\text { Strength of Geotextiles and Geotextile-Related } \\
\text { Products Using a 50-mm Probe }\end{array}$ \\
\hline ASTM E8/E8M & $\begin{array}{l}\text { Standard Test Methods for Tension Testing of } \\
\text { Metallic Materials }\end{array}$ \\
\hline ASTM E1348 & $\begin{array}{l}\text { Standard Test Method for Transmittance and Color by } \\
\text { Spectrophotometry Using Hemispherical Geometry }\end{array}$ \\
\hline ASTM G31 & $\begin{array}{l}\text { Standard Guide for Laboratory Immersion Corrosion } \\
\text { Testing of Metals }\end{array}$ \\
\hline
\end{tabular}

(Copies of these documents are available from www.astm.org or the American Society for Testing and Materials, 100 Barr Harbor Drive, West Conshohocken, PA 19428-2959.) 


\title{
MIL-DTL-32488
}

\section{SPANISH ASSOCIATION FOR STANDARDISATION AND CERTIFICATION (AENOR)}

\author{
UNE-EN ISO 13433 Geosynthetics - Dynamics perforation test (cone drop test)
}

UNE-EN $14030 \quad$ Geotextiles and geotextile-related products - Screening test method for determining the resistance to acid and alkaline liquids

(Copies of these documents are available from info@aenor.es or the Spanish Association for Standardisation and Certification, 902102201 or $914 \overline{326160 .}$

2.4 Order of precedence. Unless otherwise noted herein or in the contract, in the event of a conflict between the text of this document and the references cited herein, the text of this document takes precedence. Nothing in this document, however, supersedes applicable laws and regulations unless a specific exemption has been obtained.

\section{REQUIREMENTS}

3.1 First Article. When specified (see 6.2), a sample shall be subjected to first article inspection in accordance with 4.2 .

3.2 Material. The EBS shall be manufactured as a collapsible cellular system that is made from connected weld wire mesh panels and a geotextile fabric liner. A schematic drawing of a typical single EBS cell is shown in Figure 1. The EBS shall consist of the following materials.

3.2.1 Welded Wire Mesh Panel. The EBS shall have welded wire mesh panels made from AISI 1010 carbon steel and meet Table I and paragraph 3.3 requirements. The wire mesh spacing for all panels shall be 3 in \pm 0.125 in $(76 \mathrm{~mm} \pm 3 \mathrm{~mm})$. To maintain squareness, the two measured diagonals of the panels shall not differ by more than 0.125 in $(3 \mathrm{~mm})$ per foot $(0.305 \mathrm{~m})$. The panel shall not deviate from plane by more than 1 in $(25 \mathrm{~mm})$ for every $3 \mathrm{ft}(0.914 \mathrm{~m})$ length. Panels smaller than $3 \mathrm{ft}(0.914 \mathrm{~m})$ shall not deviate more than $0.5 \mathrm{in}(13 \mathrm{~mm})$ from plane.

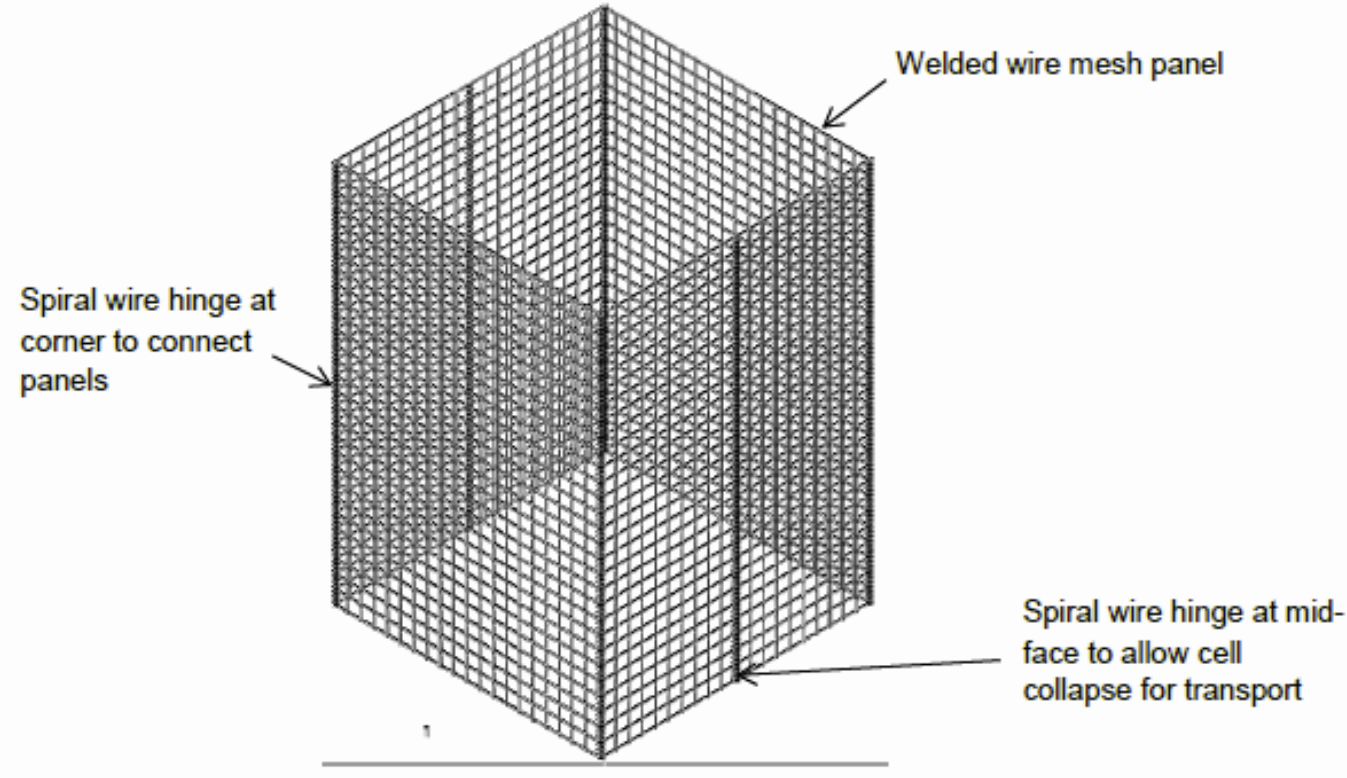

FIGURE 1. Typical EBS cell. 


\section{MIL-DTL-32488}

3.2.2 Spiral Wire Hinge. As shown schematically in Figure 1, the welded wire mesh panels shall be connected with spiral wire hinges at the corners and mid-face of each cell as appropriate for each type. The spiral wire hinges shall be made from AISI 1010 carbon steel wire and meet all requirements of Table I for nominal 0.157 in $(4 \mathrm{~mm})$ diameter wire. The hinges shall be formed with an inside diameter of 0.875 in \pm 0.039 in $(22 \mathrm{~mm} \pm 1 \mathrm{~mm})$ and pitch of 1 in \pm 0.039 in $(25 \mathrm{~mm}$ $\pm 1 \mathrm{~mm}$ ). It is the manufacturer's responsibility to ensure that the exact pitch within the allowable range shall be compatible with the exact wire mesh spacing for easy assembly of the EBS cells and easy collapse of the baskets. The ends of the spiral wire hinges must be crimped in a way so that once assembled they cannot back off of the wire panels. See Figure 2 for an example of an end crimp. Spiral wire hinges shall be long enough to extend the full height of the wire panels for each EBS type.

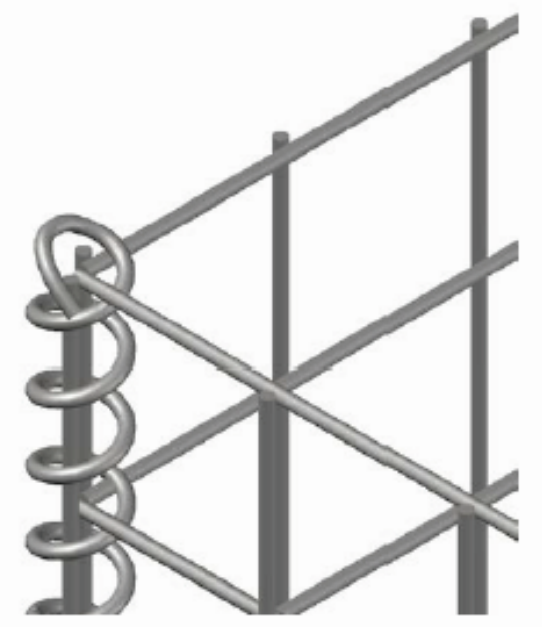

FIGURE 2. Example, crimped end on spiral wire hinge.

3.2.3 Connecting Pin. Connecting pins are used at each corner of the EBS cells to join adjacent cells together. The connecting pins will be made from 1010 carbon steel wire and meet all requirements of Table I for nominal 0.157 in $(4 \mathrm{~mm})$ diameter wire. The pins will be hooked on one end for grabbing and removal if desired. The hook will be $1.5 \mathrm{in}(38 \mathrm{~mm})$ long and have a radius of 0.687 in $(17 \mathrm{~mm})$. Where an EBS type calls for two or more separate sections in Figures $6,8,9,12,13,14,15$ and 17 , connecting pins shall be provided to join those sections. Further, a minimum of two extra connecting pins will be provided with each EBS unit of issue for connecting to adjacent units. Connecting pins shall be long enough to extend the full height of the wire panels for each EBS type.

3.2.4 Hog Ring. Hog rings are used to connect baskets stacked vertically. The hog rings shall be made from AISI 1010 carbon steel wire and meet all the requirements of Table I for nominal 0.157 in $(4 \mathrm{~mm})$ diameter wire. The hog rings shall conform to the design, dimensions, and tolerances shown in Figure 3 . A sufficient quantity shall be provided to attach hog rings at a spacing not more than 9 in $(230 \mathrm{~mm})$ along stacked baskets.

3.2.5 Geotextile Fabric. The inside of the EBS cells shall be lined on all sides with a non woven polypropylene geotextile fabric that meets Table II. The geotextile fabric shall be overlapped over the top of each cell by 3.5 in \pm 0.25 in $(90 \mathrm{~mm} \pm 6 \mathrm{~mm})$ and shall extend beyond the bottom of each cell by $3.5 \mathrm{in} \pm .25$ in $(90 \mathrm{~mm} \pm 6 \mathrm{~mm})$. The top overlaps provide a lap for stapling the fabric inside the cell and the bottom extension provides a skirt that can be placed inside lower cells when the EBS cells are stacked. The two free ends of the fabric inside of each cell will be overlapped by a minimum of $3.5 \mathrm{in}(90 \mathrm{~mm})$ so that the inside of the cell is completely lined. The overlap will be placed at the middle of a cell wall that adjoins to an adjacent cell; overlaps will not occur on an exterior face of the EBS cells. The geotextile fabric shall not burn when tested in a filled unit as described in the burn propagation test in paragraph 4.5.5. 


\section{MIL-DTL-32488}
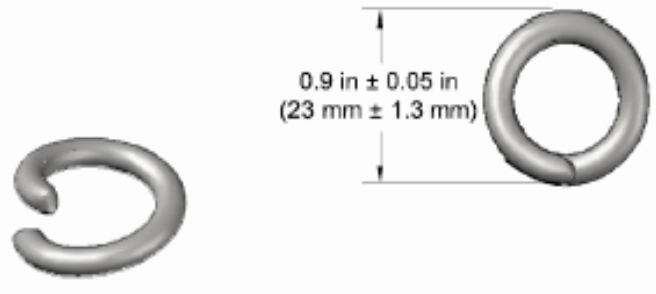

0.27 in \pm 0.05 in

$(6.9 \mathrm{~mm} \pm 1.3 \mathrm{~mm})$

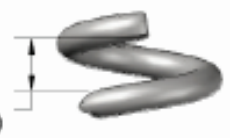

FIGURE 3. Hog ring design and dimensions.

3.2.6 Geotextile Fabric Color. The color of the geotextile fabric shall be either Class B, beige/sand or Class G, green, where the fabric color is determined in accordance with the measurement techniques of ASTM E1348, 10 degree specular excluded, UV included. The Class $\mathrm{B}$, beige/sand geotextile fabric shall conform to the CIELAB color measurement values of $\mathrm{L}^{*}$ : 54.57-57.02, $a^{*}: 3.79-4.33$, and $b^{*}: 13.71-15.93$. The Class G, green, geotextile fabric shall conform to the CIELAB color measurement values of $L^{*}: 31.41-36.70$, $a^{*}:-8.58--8.06$, and $b^{*}$ : 7.24-8.31.

3.2.7 Geotextile Fabric Staples. The geotextile fabric is secured inside of each EBS cell by stapling at the top and bottom using the typical staple pattern shown in Figure 4 . Staples will be galvanized finished flat steel wire that is minimum 0.098 in $(2.5 \mathrm{~mm})$ wide by 0.02 in $(0.5 \mathrm{~mm})$ thick. The minimum width of the staple is 0.5 in $(13 \mathrm{~mm})$. Length of the staple shall be sufficient to secure the fabric when stapled in the required pattern, see Figure 5.

3.2.8 Recycled, recovered, or environmentally preferable materials. Recycled, recovered, or environmentally preferable materials should be used to the maximum extent possible, provided that the material meets or exceeds the operational and maintenance requirements, and promotes economically advantageous life cycle costs.

3.3 Protective finish. All steel components of the EBS units shall have a zinc- $5 \%$ aluminummischmetal coating satisfying the requirements of ASTM B750 and the deposition requirements of ASTM A856. An alternative coating composition may be used, however it must provide corrosion protection that is equivalent to or greater than an ASTM B750 GALFAN coating applied at the minimum specified coating weight given in this specification. The protective finish must be provided on the wire and welds of finished product.

3.4 Small scale structural load. The EBS shall be able to withstand a minimum peak load capacity of $53,000 \mathrm{lb}(235 \mathrm{kN})$, see paragraph 4.5.6.

3.5 Design. The EBS shall conform to the design, dimensions, and tolerances specified in Table III and Figures 6 through 17. 

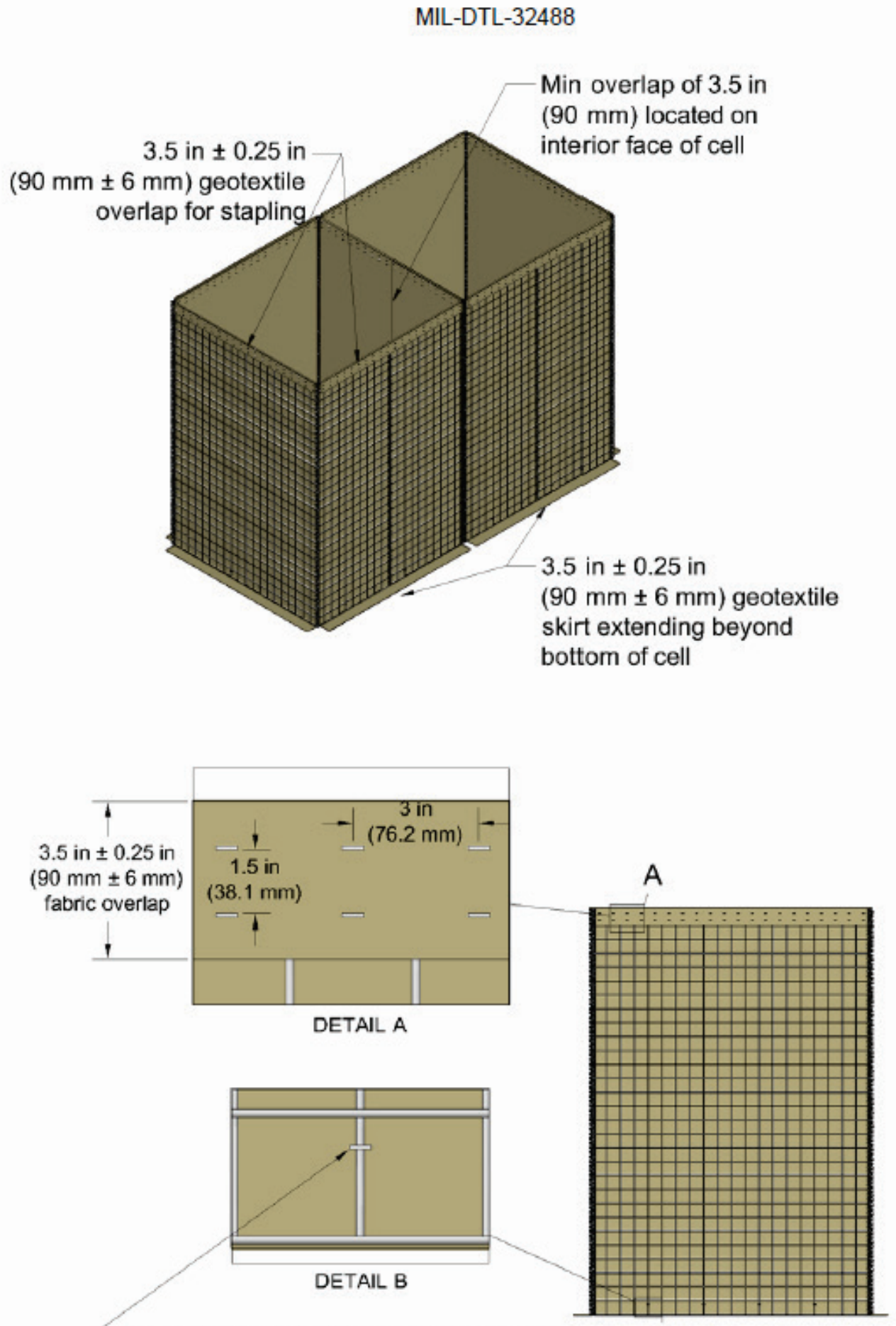

Staple geotextile along bottom row of wire mesh. Min 2 staples per panel for EBS 2, 5, 6, 9, and 11.

B Min 3 staples per panel for EBS 1, 3, 4, 8, and 12. Min 4 staples per panel for EBS 7 and 10.

FIGURE 4. Typical geotextile staple pattern 
MIL-DTL-32488

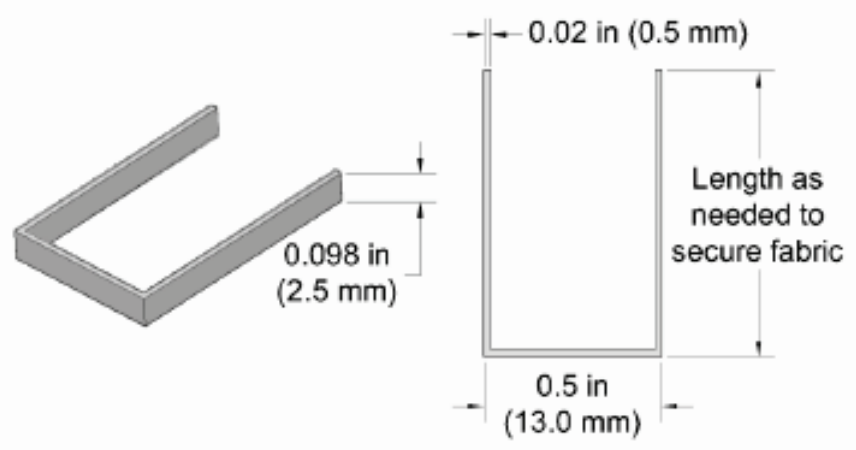

FIGURE 5. Geotextile fabric staple.

TABLE I. Wire Properties.

\begin{tabular}{|c|c|c|}
\hline Property & $\underline{0.157 \text { in }(4 \mathrm{~mm}) \text { Requirement }}$ & $\underline{0.197}$ in $(5 \mathrm{~mm})$ Requirement \\
\hline Coated diameter, $\min$ & 0.154 in $(3.90 \mathrm{~mm})$ & $0.195 \mathrm{in}(4.95 \mathrm{~mm})$ \\
\hline Uncoated diameter & $\begin{array}{l}0.151 \mathrm{in} \pm 0.003 \text { in } \\
(3.83 \mathrm{~mm} \pm 0.08 \mathrm{~mm})\end{array}$ & $\begin{array}{l}0.191 \mathrm{in} \pm 0.003 \mathrm{in} \\
(4.86 \mathrm{~mm} \pm 0.08 \mathrm{~mm})\end{array}$ \\
\hline Tensile yield strength & $\begin{array}{l}92800 \mathrm{psi} \pm 8700 \mathrm{psi} \\
(640 \mathrm{MPa} \pm 60 \mathrm{MPa})\end{array}$ & $\begin{array}{l}85600 \mathrm{psi} \pm 7250 \mathrm{psi} \\
(590 \mathrm{MPa} \pm 50 \mathrm{MPa})\end{array}$ \\
\hline Tensile ultimate strength & $\begin{array}{l}99350 \mathrm{psi} \pm 15200 \mathrm{psi} \\
(685 \mathrm{MPa} \pm 105 \mathrm{MPa})\end{array}$ & $\begin{array}{l}94300 \mathrm{psi} \pm 15200 \mathrm{psi} \\
(650 \mathrm{MPa} \pm 105 \mathrm{MPa})\end{array}$ \\
\hline Elongation at rupture & $7 \% \pm 2 \%$ & $7 \% \pm 2 \%$ \\
\hline Weld shear strength', min & $70 \%$ & $70 \%$ \\
\hline Protective finish weight, min & $0.50 \mathrm{oz} / \mathrm{ft}^{2}\left(150 \mathrm{~g} / \mathrm{m}^{2}\right)$ & $0.50 \mathrm{oz} / \mathrm{ft}^{2}\left(150 \mathrm{~g} / \mathrm{m}^{2}\right)$ \\
\hline DI mass loss, max & $0.02 \%$ & $0.02 \%$ \\
\hline
\end{tabular}

'Percentage of ultimate tensile strength. 
MIL-DTL-32488

TABLE II. Fabric Properties.

\section{Property}

Thickness, min

Mass per unit area, min

Grab tensile strength, $\mathrm{MD}^{1}$

Grab tensile strength, TD ${ }^{1}$

Grab elongation, $\mathrm{MD}^{1}$

Grab elongation, TD ${ }^{1}$

Wide width tensile strength, $\mathrm{MD}^{1}$

Wide width tensile strength, TD'

Wide width elongation, $\mathrm{MD}^{1}$

Wide width elongation, TD'

Trapezoidal tear strength, $\mathrm{MD}^{1}$

Trapezoidal tear strength, TD ${ }^{1}$

CBR puncture strength'

Cone drop test ${ }^{2}$

Apparent opening size

Permittivity

Min strength retention (1000 hr UV exposure)

Min strength retention (chemical exposure,

diesel fuel and deicing fluid)

Min strength retention (sulfuric acid)

Min strength retention (calcium hydroxide)

Min strength retention (high temperature exposure)

Min strength retention (low temperature exposure)

Min strength retention (blowing sand abrasion)

Burn propagation when filled

\author{
Requirement \\ 54 mils $(1.37 \mathrm{~mm})$ \\ $6.5 \mathrm{oz} / \mathrm{yd}^{2}\left(220.39 \mathrm{~g} / \mathrm{m}^{2}\right)$ \\ $210 \mathrm{lb} / 180 \mathrm{lb}(934 \mathrm{~N} / 800 \mathrm{~N})$ \\ $210 \mathrm{lb} / 180 \mathrm{lb}(934 \mathrm{~N} / 800 \mathrm{~N})$ \\ $80 \% / 75 \%$ \\ $80 \% / 75 \%$ \\ $85 \mathrm{lb} / \mathrm{in} / 75 \mathrm{lb} / \mathrm{in}(14.9 \mathrm{~N} / \mathrm{mm} / 13.1 \mathrm{~N} / \mathrm{mm})$ \\ $85 \mathrm{lb} / \mathrm{in} / 75 \mathrm{lb} / \mathrm{in}(14.9 \mathrm{~N} / \mathrm{mm} / 13.1 \mathrm{~N} / \mathrm{mm})$ \\ $70 \% / 60 \%$ \\ $70 \% / 60 \%$ \\ $80 \mathrm{lb} / 70 \mathrm{lb}(356 \mathrm{~N} / 311 \mathrm{~N})$ \\ $80 \mathrm{lb} / 70 \mathrm{lb}(356 \mathrm{~N} / 311 \mathrm{~N})$ \\ $550 \mathrm{lb} / 480 \mathrm{lb}(2447 \mathrm{~N} / 2135 \mathrm{~N})$ \\ 0.787 in / 0.866 in $(20 \mathrm{~mm} / 22 \mathrm{~mm})$ \\ 0.004 in -0.005 in $(0.11 \mathrm{~mm}-0.13 \mathrm{~mm})$ \\ $1.1 \mathrm{~s}^{-1}-1.6 \mathrm{~s}^{-1}$ \\ $80 \%$ \\ $90 \%$ \\ $90 \%$ \\ $80 \%$ \\ $90 \%$ \\ $90 \%$ \\ $85 \%$ \\ no flame spread
}

${ }^{1}$ Given as min allowable average/min allowable single test value.

${ }^{2}$ Given as max allowable average/max allowable single test value.

TABLE III. EBS Dimensions and Weight.

\begin{tabular}{|c|c|c|c|c|c|c|c|c|c|c|}
\hline \multirow[t]{3}{*}{ Type } & \multirow{2}{*}{\multicolumn{2}{|c|}{ Height' ${ }^{1}$}} & \multirow{2}{*}{\multicolumn{2}{|c|}{ Width' }} & \multirow{2}{*}{\multicolumn{2}{|c|}{ Length ${ }^{2}$}} & \multirow{2}{*}{\multicolumn{2}{|c|}{$\begin{array}{c}\text { Wire } \\
\text { Diameter }^{3}\end{array}$}} & \multirow{2}{*}{\multicolumn{2}{|c|}{$\frac{\text { Weight }}{\text { Max }}$}} \\
\hline & & & & & & & & & & \\
\hline & $\mathrm{ft}$ in & $\mathrm{m}$ & $\mathrm{ft}$ in & $\mathrm{m}$ & $\mathrm{ft}$ in & $\mathrm{m}$ & in & $\mathrm{mm}$ & $\mathrm{lb}$ & $\mathrm{kg}$ \\
\hline 1 & $4^{\prime} 6^{\prime \prime}$ & 1.37 & $3^{\prime} 6^{\prime \prime}$ & 1.06 & $32^{\prime} 9^{\prime}$ & 10 & 0.157 & 4 & 343 & 156 \\
\hline 2 & 2 & 0.61 & $2^{\prime}$ & 0.61 & $4^{\prime}$ & 1.22 & 0.157 & 4 & 23 & \begin{tabular}{|l|}
10.5 \\
\end{tabular} \\
\hline 3 & $3^{\prime} 3^{\prime \prime}$ & 1 & $3^{\prime} 3^{\prime}$ & 1 & $32^{\prime} 9^{\prime \prime}$ & 10 & 0.157 & 4 & 246 & \begin{tabular}{|l|l}
112 \\
\end{tabular} \\
\hline 4 & $3^{\prime} 3^{\prime \prime}$ & 1 & $5^{\prime}$ & 1.52 & $32^{\prime} 9^{\prime \prime}$ & 10 & $\begin{array}{ll}0.157 \\
\end{array}$ & 4 & 392 & 178 \\
\hline 5 & 2 & 0.61 & $2^{\prime}$ & $\begin{array}{l}0.61 \\
\end{array}$ & $10^{\prime}$ & 3.05 & 0.157 & 4 & 53 & 24 \\
\hline 6 & $5^{\prime} 6^{n}$ & 1.68 & $2^{\prime}$ & 0.61 & $10^{\prime}$ & 3.05 & 0.157 & 4 & 101 & 46 \\
\hline 7 & $7^{\prime} 3^{\prime \prime}$ & 2.21 & $7^{\prime}$ & 2.13 & $91^{\prime}$ & 27.74 & 0.197 & 5 & 2129 & \begin{tabular}{|l}
967 \\
\end{tabular} \\
\hline 8 & $4^{\prime} 6^{\prime \prime}$ & 1.37 & $4^{\prime}$ & 1.22 & $32^{\prime} 9^{\prime \prime}$ & 10 & 0.157 & 4 & 351 & 159.5 \\
\hline 9 & $3^{\prime} 3^{\prime \prime}$ & 1 & $2^{\prime} 6^{n}$ & 0.76 & $30^{\prime}$ & 9.14 & 0.157 & 4 & 235 & \begin{tabular}{|l|l}
107 \\
\end{tabular} \\
\hline 10 & $7^{\prime} 3^{n}$ & 2.21 & $5^{\prime}$ & 1.52 & $100^{\prime}$ & 30.5 & $\begin{array}{ll}0.197 \\
\end{array}$ & 5 & 2275 & 1034 \\
\hline 11 & 4 & 1.22 & $1^{\prime}$ & 0.30 & $4 '$ & 1.22 & 0.197 & 5 & 35 & 16 \\
\hline 12 & $7^{\prime}$ & 2.13 & $3^{\prime} 6^{n}$ & 1.06 & $108^{\prime}$ & 33 & 0.157 & 4 & 1793 & 815 \\
\hline
\end{tabular}

${ }^{1}$ Tolerance \pm 0.25 in $(6.35 \mathrm{~mm})$.

${ }^{2}$ Tolerance \pm 0.5 in $(12.7 \mathrm{~mm})$.

${ }^{3}$ Wire diameters are nominal. See Table II for specific diameter requirements. 


\section{MIL-DTL-32488}

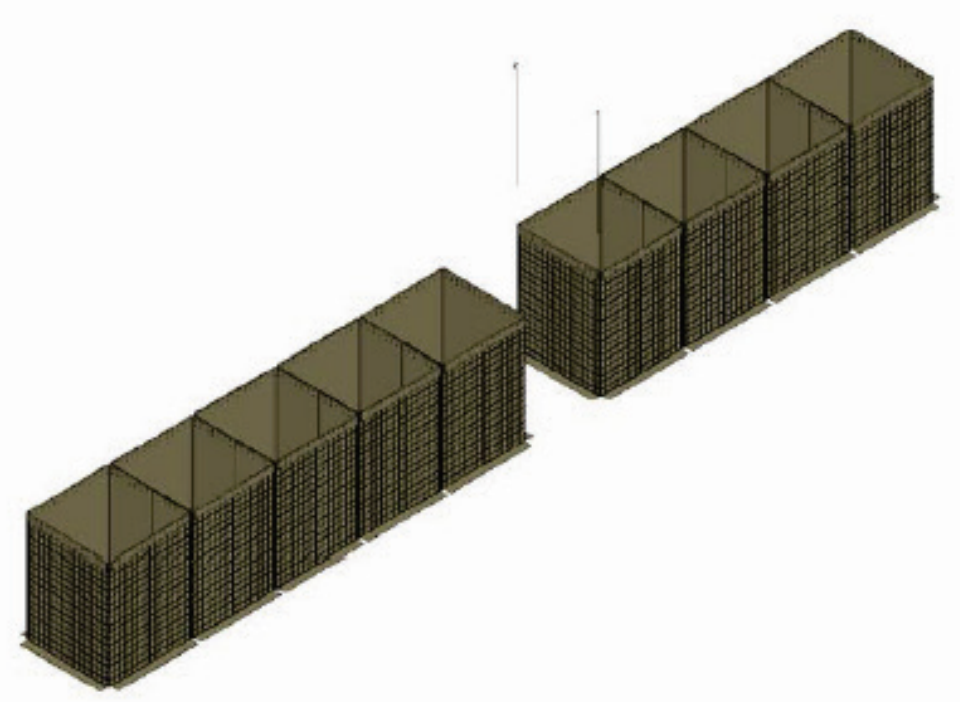

FIGURE 6. Type 1 (9 cells $(1 \times 5,1 \times 4))$.

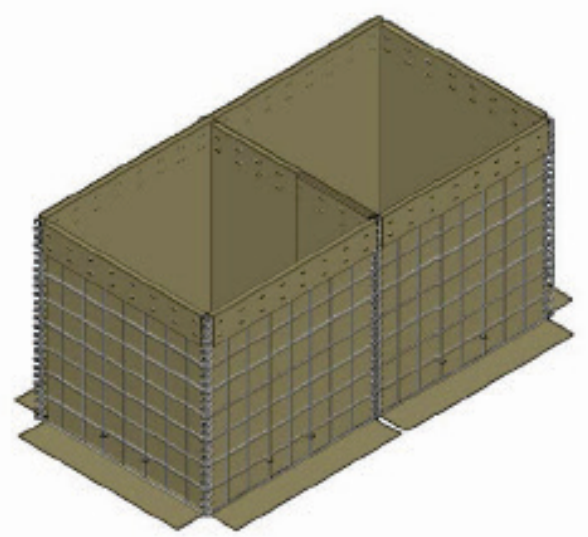

FIGURE 7. Type 2 ( 2 cells).

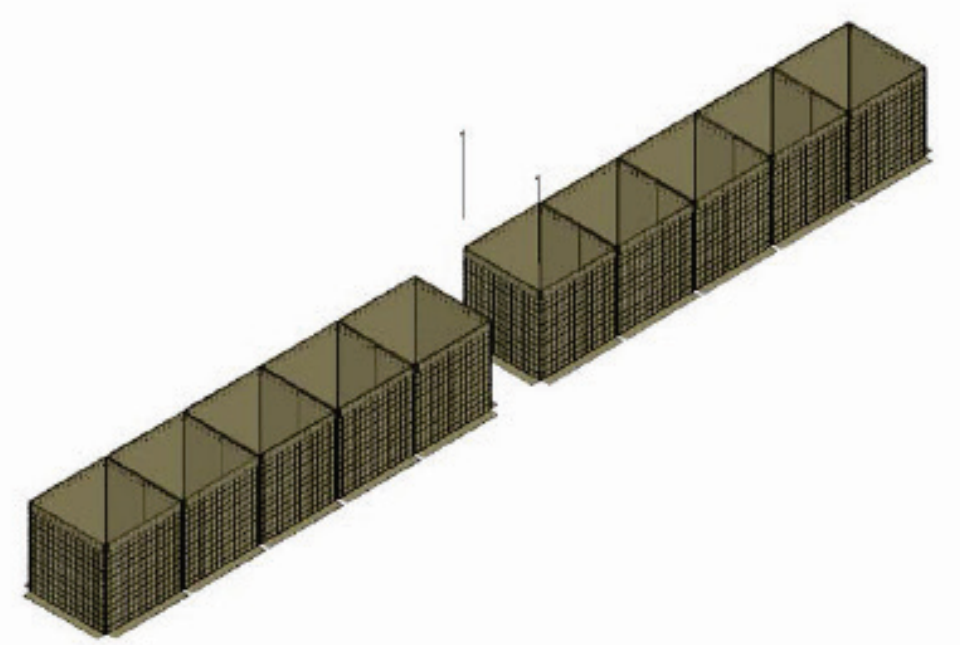

FIGURE 8 . Type $3(10$ cells $(2 \times 5))$. 
MIL-DTL-32488

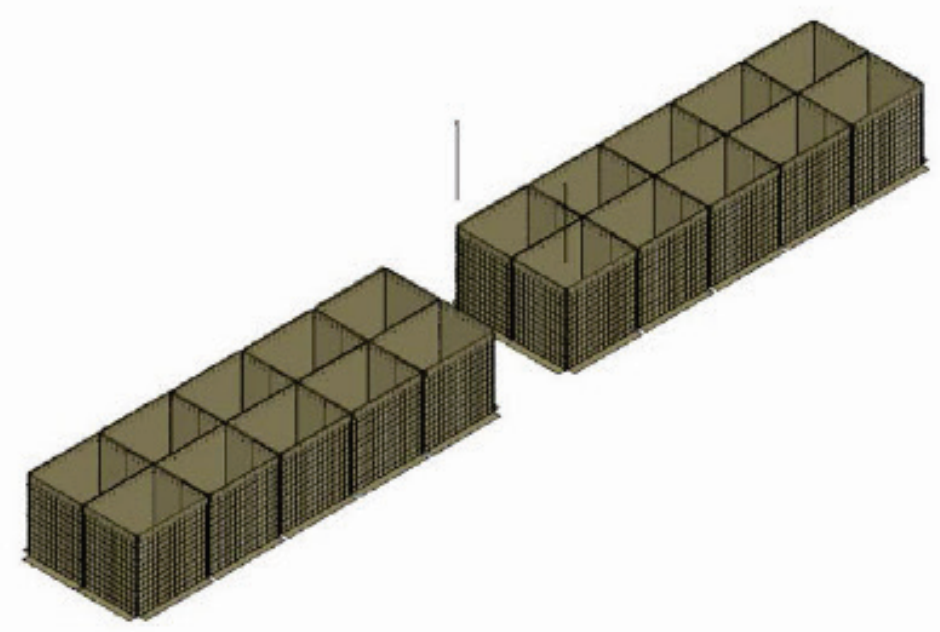

FIGURE 9. Type 4 (20 cells ( $2 \times 10))$.

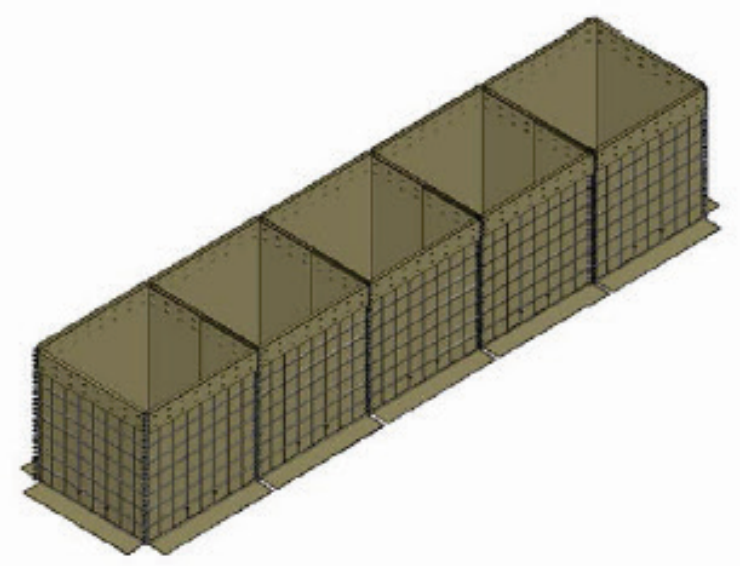

FIGURE 10 . Type 5 (5cells (1x5)).

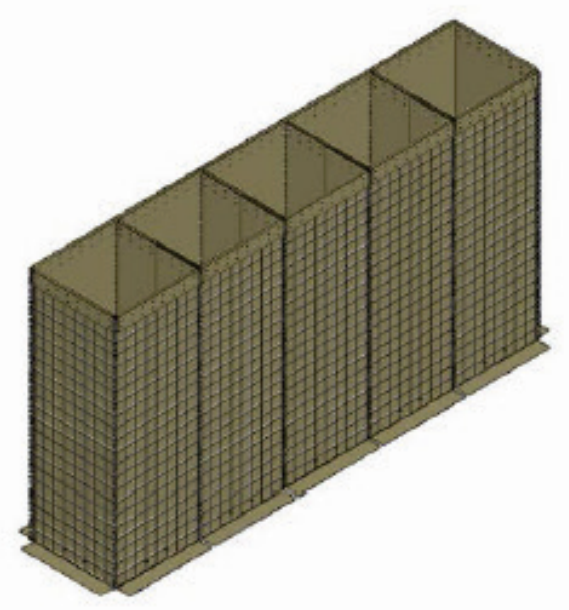

FIGURE 11. Type 6 ( 5 cells $(1 \times 5))$. 
MIL-DTL-32488

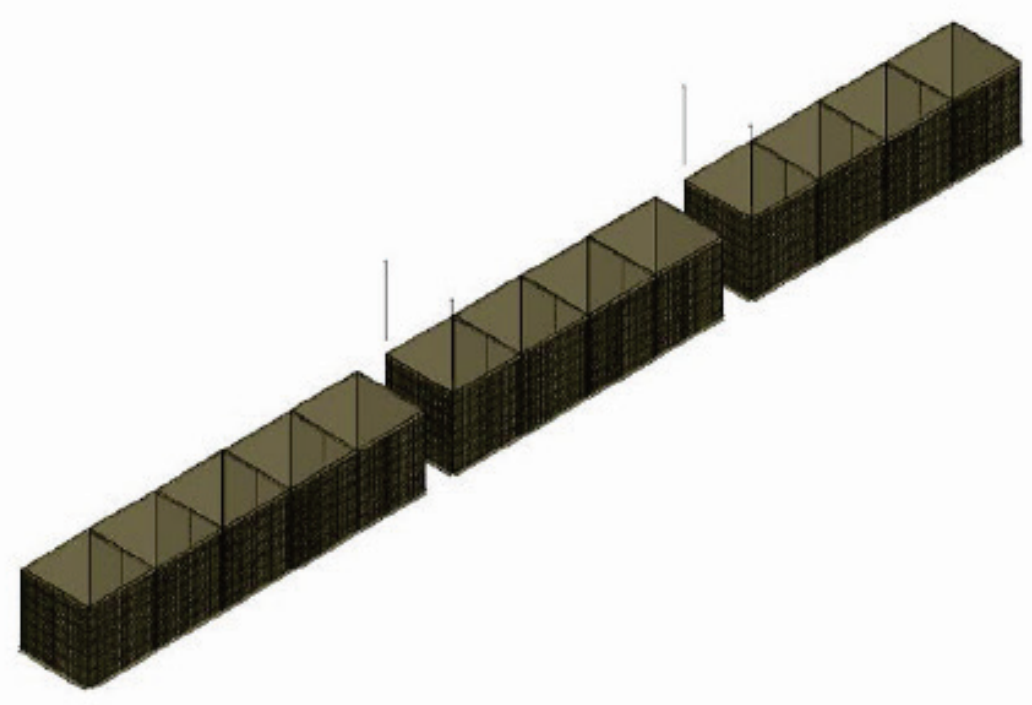

FIGURE 12. Type 7 ( 13 cells $(1 \times 5,2 \times 4))$.

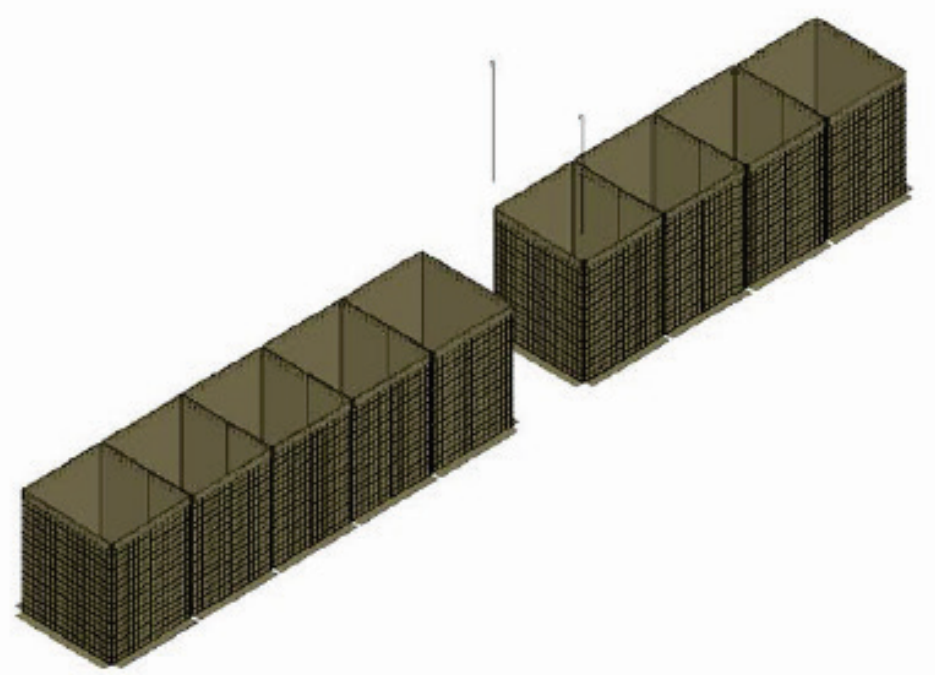

FIGURE 13. Type 8 (9 cells $1 \times 4,1 \times 5))$. 
MIL-DTL-32488

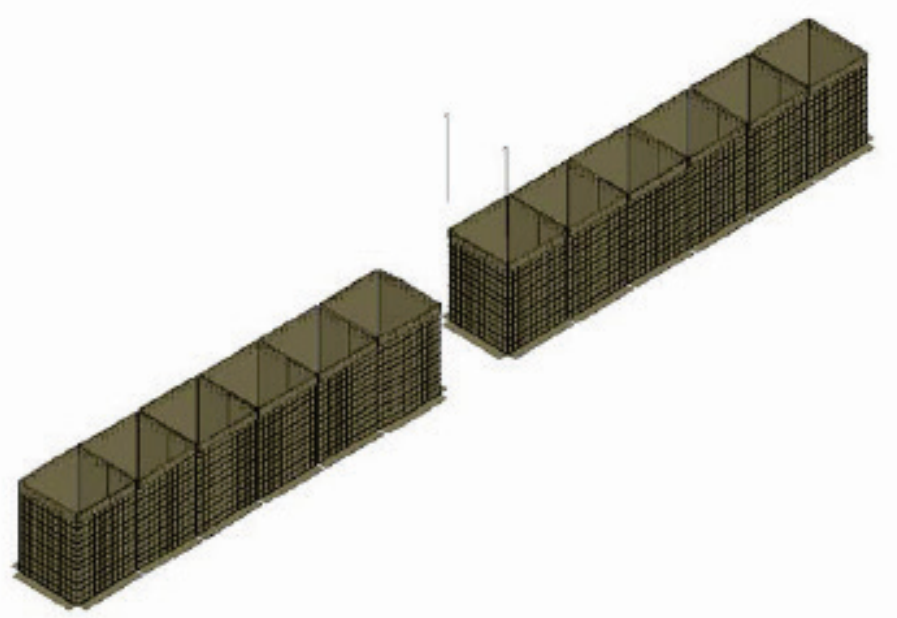

FIGURE 14. Type 9 ( 12 cells $2 \times 6))$.

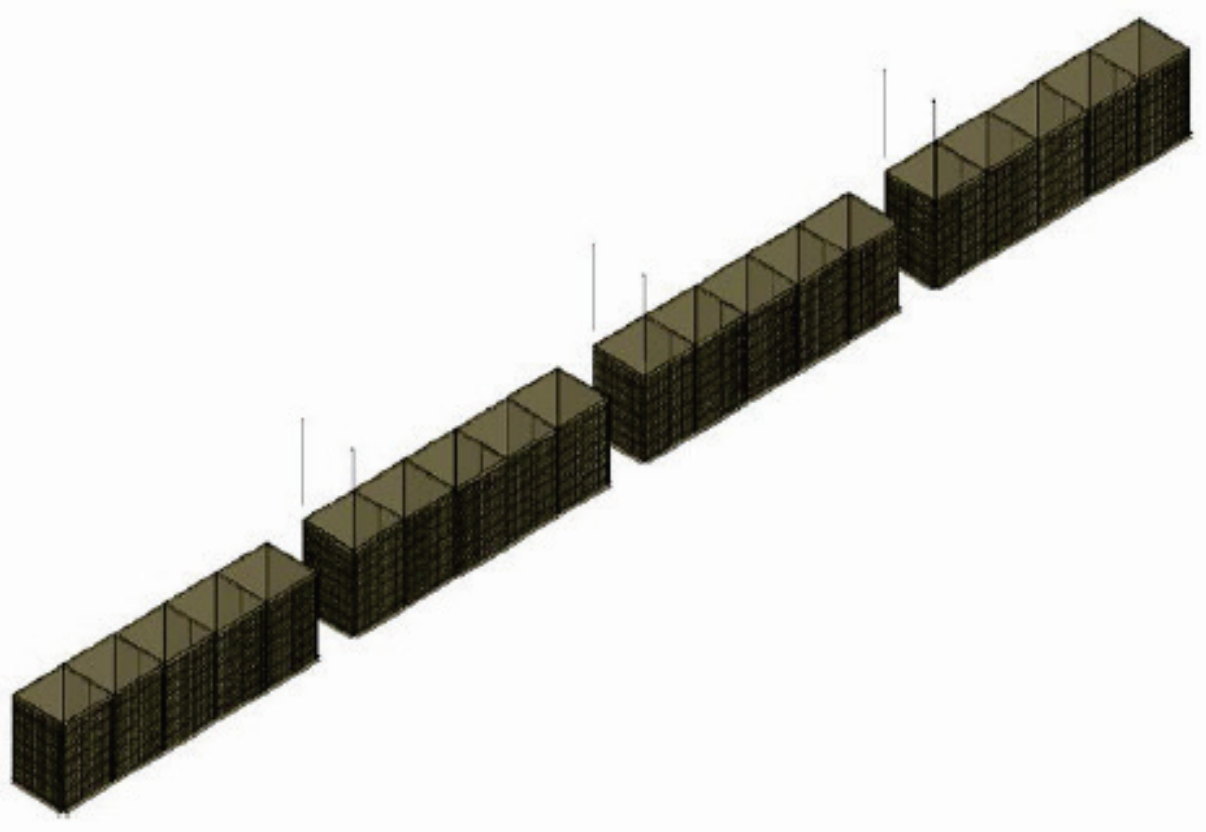

FIGURE 15 . Type 10 ( 20 cells $(4 \times 5)$. 
MIL-DTL-32488

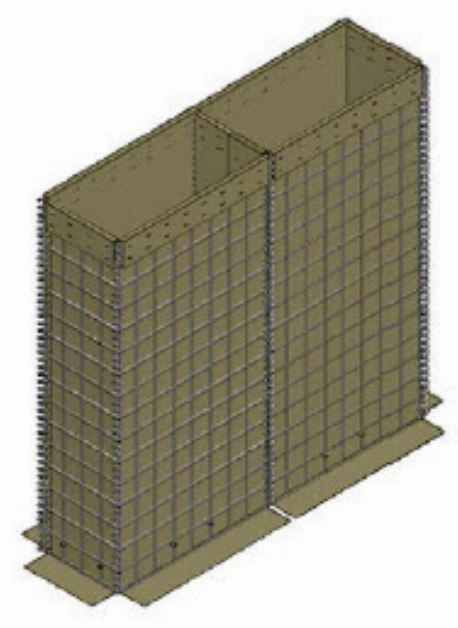

FIGURE 16. Type 11 ( 2 cells).

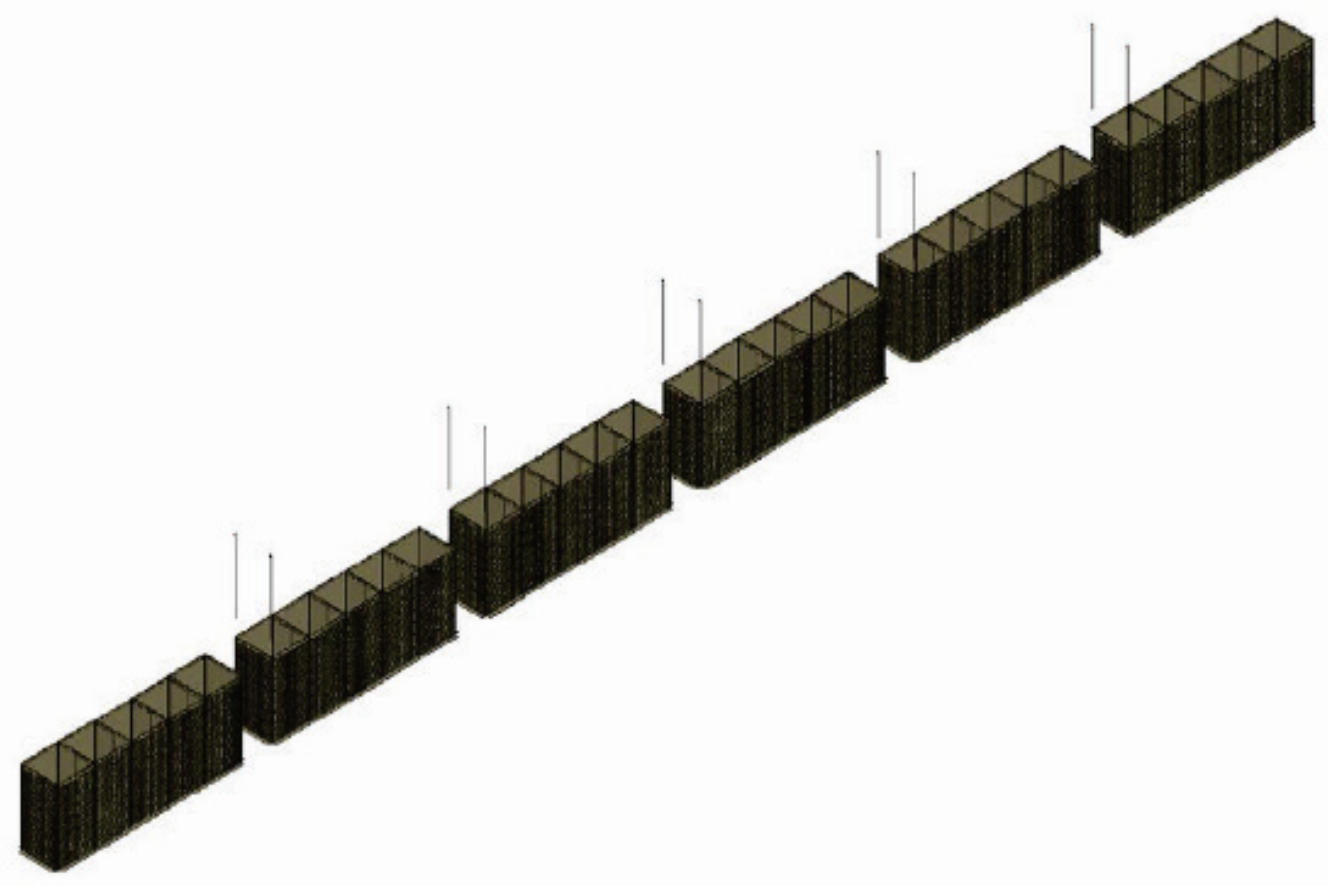

FIGURE 17. Type 12 (30 cells (6x5)). 
MIL-DTL-32488

\section{VERIFICATION}

4.1 Classification of inspection. The inspection and testing of the EBS shall be classified as follows:

a. First article inspection (see 4.2)

b. Conformance inspection (see 4.3)

4.2 First article inspection. First article inspection shall consist of all the tests specified (see 4.5).

4.3 Conformance inspection. Conformance inspection shall include the following tests.

4.3.1 Welded Wire Mesh Panel. The conformance tests for the welded wire mesh panels shall include protective finish, First Article Tests (paragraph 4.5.3), and the following tests from Table IV: wire coated diameter, wire uncoated diameter, wire galvanic coating weight, wire tensile yield strength, wire tensile ultimate strength, wire elongation at rupture, and weld shear strength.

4.3.2 Geotextile Fabric. The conformance tests for the geotextile fabric shall include the following tests from Table IV: fabric thickness, fabric mass per unit area, fabric grab elongation, and geotextile fabric tensile strength.

4.4 Sampling. One barrier shall be taken from each lot and used for each conformance inspection.

4.4.1 Lot Size. A lot shall consist of all barriers of the same type and class, manufactured under essentially the same conditions and submitted for inspection at one time.

\subsection{Tests.}

4.5.1 Material. The contractor shall furnish certification that the material complies with the requirements specified in 3.2 , excluding the burn propagation test.

4.5.2 First article test samples. The contractor shall provide to the government three Type 1 and three Type 7 barriers to perform the burn propagation (paragraph 4.5.5) and small scale structural load (paragraph 4.5.6) tests. Samples must include at least one Class B(beige/sand) and one Class $\mathrm{G}$ (green) barrier for visual color confirmation. See paragraph 6.4 for test laboratory address.

4.5.3 First article tests. The first article tests shall include paragraphs 4.5.4, 4.5.5 and 4.5.6 and tested as specified in Table IV. Any barrier which fails one or more tests shall be rejected.

4.5.4 Protective finish. The contractor shall furnish certification that the protective finish conforms to the requirements of the specifications referenced in 3.3 .

4.5.5 Burn propagation test. The burn propagation test shall be conducted by exposing a filled EBS cell to an open flame and assessing the burn potential of the fabric. The EBS cell is filled with a clean concrete sand with moisture content of 5 to 7.5 percent. A gas flame (equivalent to propane gas with flow rate of $1600 \mathrm{ml} / \mathrm{min}$.) is then applied to the wall of the cell, with the flame source not more than 1 in $(25 \mathrm{~mm})$ away from the wall. The flame is applied for 20 seconds and then removed. After removal of the flame, any fabric that had begun to burn must be selfextinguishing within 20 seconds.

4.5.6 Small scale structural load test. The small scale structural load test is conducted to evaluate the composite performance of the EBS cell under application of a vertical load. To perform the test a single EBS 1 cell is filled with a coarse sand (Runyon sand or equivalent) that is hand tamped in approximate 12 in $(30 \mathrm{~cm})$ lifts. The filled cell is then tested to failure by applying an increasing vertical load with a structural load testing device. A spreader plate is used to apply the 


\section{MIL-DTL-32488}

load uniformly over the top of the entire cell. Three cells shall be tested and have a minimum average peak load capacity of $53,000 \mathrm{lb}(235 \mathrm{kN})$.

\section{TABLE IV. First Article Tests.}

\section{Property}

Wire coated diameter, $\min$

Wire uncoated diameter

Wire tensile yield strength

Wire tensile ultimate strength

Wire elongation at rupture

Weld shear strength, min

Wire galvanic coating weight, min

Coil coated diameter, min

Coil uncoated diameter

Coil galvanic coating weight, min

Connecting pin coated diameter, min

Connecting pin uncoated diameter

Connecting pin galvanic coating weight, $\mathrm{min}$

DI mass loss ${ }^{1}$

Fabric thickness, min

Fabric mass per unit area, min

Fabric grab tensile strength, MD

Fabric grab tensile strength, TD

Fabric grab elongation, MD

Fabric grab elongation, TD

Fabric wide width tensile strength, MD

Fabric wide width tensile strength, TD

Fabric wide width elongation, MD

Fabric wide width elongation, TD

Fabric trapezoidal tear strength, MD

Fabric trapezoidal tear strength, TD

Fabric CBR puncture strength

Fabric cone drop test

Fabric apparent opening size

Fabric permittivity

Fabric min strength retention (1000 hr UV exposure $)^{2}$

Fabric min strength retention (chemical exposure,

diesel fuel and deicing fluid) $)^{3}$

Fabric min strength retention (sulfuric acid) ${ }^{2}$

Fabric min strength retention (calcium hydroxide) ${ }^{2}$

Fabric min strength retention (high temperature exposure)

Fabric min strength retention (low temperature exposure) ${ }^{2}$

Fabric min strength retention (blowing sand abrasion) ${ }^{2}$

Fabric color

Burn propagation

Small scale structure load
Test Method $\quad$ Requirement

Table I

Table I

Table I

Table I

Table I

Table I

Table I

Table I

Table I

Table I

Table I

Table I

Table I

Table I

Table II

Table II

Table II

Table II

Table II

Table II

Table II

Table II

Table II

Table II

Table II

Table II

Table II

Table II

Table II

Table II

Table II

Table II

Table II

Table II

Table II

Table II

Table II

par. 3.2 .6

Table II

par. 3.3

'Test performed with coated wire for a testing time of 14 days on deionized water.

${ }^{2}$ Strength retained measured using Strip Tensile test from ASTM D5035.

${ }^{3}$ Strength retained measured using Wide Width Tensile test from ASTM D4595. 
MIL-DTL-32488

\title{
5. PACKAGING
}

5.1 Packaging. For acquisition purposes, the packaging requirements shall be as specified in the contract or order (see 6.2). When packaging of materiel is to be performed by DoD or inhouse contractor personnel, these personnel need to contact the responsible packaging activity to ascertain packaging requirements. Packaging requirements are maintained by the Inventory Control Point's packaging activities within the Military Service or Defense Agency, or within the military service's system commands. Packaging data retrieval is available from the managing Military Department's or Defense Agency's automated packaging files, CD-ROM products, or by contacting the responsible packaging activity.

\section{NOTES}

(This section contains information of a general or explanatory nature that may be helpful, but is not mandatory.)

6.1 Intended use. The EBS specified herein is intended to provide protection from visual detection, small arms fire, indirect fire, perimeter intrusion and the like.

6.2 Acquisition requirements. Acquisition documents should specify the following:
a. Title, number and date of this specification.
b. Type and class (see 1.2).
c. If first article samples are required (see 3.1).
d. Packaging requirements (see 5.1).

\subsection{Subject term (key word) listing.}

Connecting pin

Gabion

Geotextile fabric

Spiral wire hinge

Welded wire mesh panel

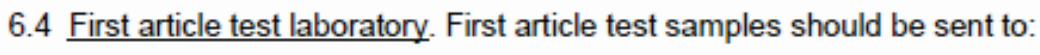

\author{
U.S. Army Research and Development Center \\ CEERD-GS-V \\ 3909 Halls Ferry Road \\ Vicksburg, MS 39180
}

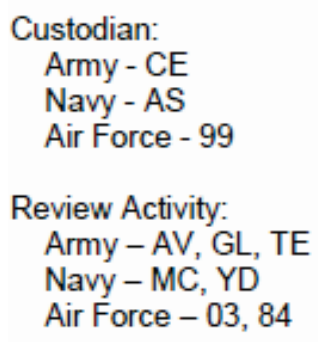

Preparing Activity:

DLA - IS

(Project 5450-2014-002)

NOTE: The activities listed above were interested in this document as of the date of document. Since organizations and responsibilities can change, you should verify the currency of the information above using the ASSIST Online database at https://assist.dla.mil. 


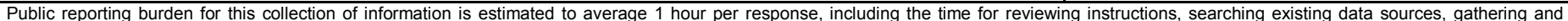

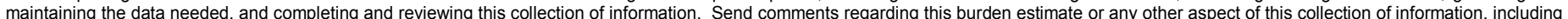

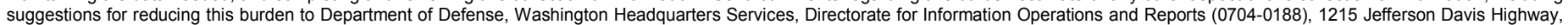

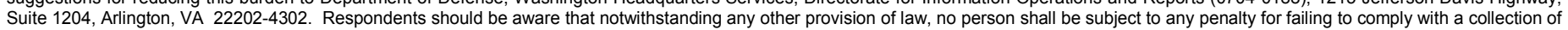
information if it does not display a currently valid OMB control number. PLEASE DO NOT RETURN YOUR FORM TO THE ABOVE ADDRESS.
1. REPORT DATE (DD-MM-YYYY) 2. REPORT TYPE

$$
\text { 3. DATES COVERED (From - To) }
$$

February 2017

Final Technical Report

\section{TITLE AND SUBTITLE}

Performance of HESCO Bastion Units Under Combined Normal and Cyclic Lateral Loading

5a. CONTRACT NUMBER

5b. GRANT NUMBER

5c. PROGRAM ELEMENT NUMBER

6. AUTHOR(S)

Ghassan K. Al-Chaar, Marion L. Banko, Brian Eick, and Thomas A. Carlson

5d. PROJECT NUMBER

P2 445442; MIPRW58XUW41133620 5e. TASK NUMBER

5f. WORK UNIT NUMBER

8. PERFORMING ORGANIZATION REPORT NUMBER

ERDC/CERL TR-17-4

U.S. Army Engineer Research and Development Center

Construction Engineering Research Laboratory

P.O. Box 9005

Champaign, IL 61826-9005

9. SPONSORING / MONITORING AGENCY NAME(S) AND ADDRESS(ES)

10. SPONSOR/MONITOR'S ACRONYM(S)

U.S. Army Engineer District-Kansas City

601 E. 12th Street

Kansas City, Mo 6410

11. SPONSOR/MONITOR'S REPORT NUMBER(S)

\section{DISTRIBUTION / AVAILABILITY STATEMENT}

Approved for public release; distribution is unlimited.

\section{SUPPLEMENTARY NOTES}

\section{ABSTRACT}

To help reduce the costs and logistical requirements for establishing forward operating bases (FOBs), the U.S. Army investigates construction methods that use indigenous materials in place of commercial materials manufactured far away. An established construction system called the HESCO bastion, currently used in theater for force protection, derives its mass and load resistance from indigenous soils placed in manufactured steel and geotextile containment modules. Using this system for other FOB structures, such as soldier housing, could greatly reduce costs and logistical burdens for Class 4 construction materials. Before developing such applications, however, the load-resisting characteristics of HESCO units must be tested for incorporation into new engineering guidance.

In this study a HESCO unit was filled with dry, coarse sand and subjected to combination of normal and lateral loads at four separate intensities. The interaction of normal and lateral loads was investigated, as well as the cyclic loading hysteresis. A lateral load capacity for HESCO bastions was determined based on the applied normal load. The results validated the suitability of HESCO units as load-bearing structural members for temporary soldier housing in FOBs located in remote areas of operation.

\section{SUBJECT TERMS}

Military bases, Barracks, Military construction operations, Building materials, Geotextiles, Load factor design

\begin{tabular}{|c|c|c|c|c|c|}
\hline \multicolumn{3}{|c|}{ 16. SECURITY CLASSIFICATION OF: } & $\begin{array}{l}\text { 17. LIMITATION } \\
\text { OF ABSTRACT }\end{array}$ & $\begin{array}{l}\text { 18. NUMBER } \\
\text { OF PAGES }\end{array}$ & $\begin{array}{l}\text { 19a. NAME OF RESPONSIBLE } \\
\text { PERSON }\end{array}$ \\
\hline $\begin{array}{l}\text { a. REPORT } \\
\text { Unclassified }\end{array}$ & $\begin{array}{l}\text { b. ABSTRACT } \\
\text { Unclassified }\end{array}$ & $\begin{array}{l}\text { c. THIS PAGE } \\
\text { Unclassified }\end{array}$ & SAR & 79 & $\begin{array}{l}\text { 19b. TELEPHONE NUMBER (include } \\
\text { area code) }\end{array}$ \\
\hline
\end{tabular}

